\title{
WYPISY ŹRÓDLOWE DO BIOGRAFII POLSKICH BISKUPÓW I OPATÓW Z CZASÓW RZECZYPOSPOLITEJ OBOJGA NARODÓW ORAZ NIEWOLI NARODOWEJ DOBY ZABORÓW (XVI - XIX W.)
}

\author{
(CZ. X)
}

Dziesiąta część kontynuowanych na łamach półrocznika „Archiwa, Biblioteki i Muzea Kościelne" Wypisów źródlowych, obszerniejsza od poprzednich, zawiera kategorię świadectw dotychczas jeszcze nie prezentowanych w ramach tej serii, niemniej zapowiadanych we wprowadzeniu do pierwszej części rozpoczętego przed ośmiu laty cyklu. Mowa o - szeroko rozumianych - poświadczeniach konsekracji biskupich nowych członków episkopatu, dopełnianych w rozmaitym czasie i okolicznościach. Owe testimonia consecrationis, jak zwykło się je określać, miały niekiedy postać samoistnego dokumentu, kiedy indziej adnotacji w księgach czynności pontyfikalnych (acta functionum pontificalium), z rzadka wpisu w episcopaliach lub aktach kapitulnych (acta actorum capituli), gdzie informacje o udzielanych w świątyni katedralnej lub kolegiackiej sakrach zdarzają się nadzwyczaj sporadycznie (jeśli już, to u schyłku okresu objętego ramami chronologicznymi niniejszego cyklu). W poniższym zbiorze, zawierającym świadectwa o święceniach biskupich łącznie 195 członków staropolskiego i porozbiorowego episkopatu katolickiego z ziem $\mathrm{w}$ różny sposób związanych z polską organizacją kościelną (4 z XV w, 7 z XVI w., 43 z XVII w., 91 z XVIII w., 50 z XIX w.), uwzględniono również pewną liczbę precyzyjnych w warstwie faktografii zapisek kronikarskich i diariuszowych (także wzmianek w korespondencji), w niejednym przypadku wypełniających lukę, jaka istnieje na okoliczność niezachowania się urzędowego poświadczenia danej konsekracji ${ }^{1}$.

${ }^{1}$ Przeglądu pod tym kątem z kolei szesnastowiecznych, tyle że wydanych wcześniej drukiem diariuszy z terenów ówczesnej Polski, piszący te słowa dokonał w publikacji zamieszczonej na łamach „Biuletynu Biblioteki Jagiellońskiej”, która to książnica przechowuje bodaj najliczniejszy zbiór tego rodzaju rodzimych zabytków z doby Złotego Wieku - K. R. Prokop, Staropolskie diariusze z XVI stulecia jako źródło informacji do dziejów hierarchii kościelnej państwa polsko-litewskiego doby Złotego Wieku, „Biuletyn Biblioteki Jagiellońskiej”, 60 (2010) s. 47-83. 
W obecnym «korpusie sakr» pominięto natomiast te spośród wnoszących coś do interesującej nas tematyki świadectw, które od tych uwzględnionych różnią się na okoliczność zdecydowanie mniejszego waloru wiarygodności, zmuszając badacza to traktowania ich w kategoriach źródeł drugorzędnego charakteru, wobec którego trudno o dalej idące zaufanie. Mamy na myśli w szczególności zeznania świadków w tzw. procesach informacyjnych, poprzedzających translacje biskupów z jednej stolicy na drugą, gdzie na pytanie, czy hierarcha, do którego proces się odnosił, przyjął święcenia biskupie, padały odpowiedzi często bardzo ogólnikowe, albo też zawierające mylne wiadomości (przez zeznającego podawane niemniej bona fide), choć bywają i takie, które pod względem szczegółowości tudzież precyzji w zasadzie w niczym nie ustępują ujętym w formę aktu notarialnego poświadczeniom dopełnionej sakry. Aby wszakże nie wprowadzać niepożądanego chaosu, lecz - przeciwnie - dążyć do pewnego uporządkowania i systematyzacji prezentowanego materiału źródłowego, wszystkie informacje o sakrach członków staropolskiego episkopatu, zaczerpnięte ze wspomnianych zeznań świadków w procesach (a więc również te ujmujące precyzją), pominięto w obecnej części Wypisów źródłowych (także przez wzgląd na znaczną i bez tego jej objętość), nastawiając się na ich późniejsze zaprezentowanie. $Z$ innych względów tak samo pominięto wiadomości o sakrach, na jakie można natrafić w drukach z okresu przed- i porozbiorowego, w tym również w najstarszej prasie periodycznej, świadomie ograniczywszy się wyłącznie do świadectw niepublikowanych, zaczerpniętych bezpośrednio $\mathrm{z}$ archiwaliów ${ }^{2}$.

Zaprezentowane niżej przekazy spisane zostały w przeważającej większości po łacinie, a tylko w pojedynczych przypadkach ówczesną polszczyzną albo po włosku. Jakkolwiek przytłaczająca ich większość odnosi się do episkopatu obrządku łacińskiego, niemniej na końcu pomieszczono osobno trzynaście świadectw traktujących o sakrach hierarchów obrządku grecko-katolickogo (11) i ormiańsko-katolickiego (2), spisanych również w języku łacińskim. W obu grupach postaci obowiązuje kolejność alfabetyczna (przy czym do jednej osoby odnosi się niekiedy więcej aniżeli pojedynczy wpis), zaś poszczególne nagłówki zakomponowane zostały według schematu przyjętego i stosownego w poprzednich częściach Wypisów źródłowych (przypomnijmy, że podawane w nawiasie po nazwisku i imieniu - lub imionach - nazwy stolic biskupich wskazują na kolejne etapy kościelnej kariery danego hierarchy, przy czym kursywą odróżniano diecezję, w której «bohater» zapiski promowany został na funkcję sufragana, natomiast dodatkowe umieszczenie jej nazwy w nawiasie kwadratowym oznacza, iż jakkolwiek wskazany członek episkopatu był ustanowiony do posługi w odnośnym Kościele

${ }^{2}$ Tego rodzaju przekazy z osiemnastowiecznej prasy warszawskiej zostały zaprezentowane niegdyś przez autora tych słów - w formie opatrzonych przypisami regestów - tak samo na łamach „Archiwów, Bibliotek i Muzeów Kościelnych”. - K.R. Prokop, Wiadomości do biografii biskupów oraz opatów i ksień z ziem Rzeczypospolitej Obojga Narodów z osiemnastowiecznej prasy warszawskiej doby saskiej i stanistawowskiej (1729-1795), „Archiwa, Biblioteki i Muzea Kościelne”, 86 (2006) s. 287-329. W tegorocznym tomie Biuletynu Biblioteki Jagiellońskiej został złożony do druku przez piszącego te słowa tekst podobnego charakteru, pt. Wypisy z XVIII- $i$ XIX-wiecznej prasy periodycznej na temat sakr biskupów Kościoła katolickiego z historycznych ziem polskich. 
partykularnym, niemniej nie wiązało się to z promowaniem na miejscową sufraganię $^{3}$ - chyba, iż rzecz dotyczy tzw. sufraganii okręgowych, ale wówczas mamy do czynienia z zapisem podwójnym - np. Kraków [Sandomierz] czy Warszawa [ towicz]). Powiększająca się z tomu na tom obfitość materiałów do biografii biskupów i opatów, zawartych w kolejnych częściach Wypisów źródtowych, co raz trudniejsza do ogarnięcia dla korzystającego, niewątpliwie wymagać będzie na koniec postulowanego przez recenzentów wydawniczych zbiorowego indeksu, ułatwiającego na przyszłość poruszanie się po tak różnorodnym zasobie informacji. W tym miejscu poprzestaniemy wyłącznie na wzmiance, że świadectwa pomieszczone w częściach I do X serii odnoszą się do życiorysów w sumie 560 postaci, niegdyś kształtujących oblicze życia kościelnego (i nie tylko) na ziemiach polskich od wczesnej nowożytności (czy nawet schyłku wieków średnich), aż po stulecie XIX włącznie. Tym samym seria ta toruje drogę ku powstaniu kolejnych, oczekiwanych opracowań z dziedziny prozopografii, czyli biografii zbiorowej, przeżywającej aktualnie na gruncie rodzimym swój renesans.

${ }^{3}$ Owa kategoria «nadliczbowych» biskupów pomocniczych, ustanawianych do posługi w diecezjach, gdzie zazwyczaj czynny był już «pełnoprawny» sufragan, nieposiadająca dotychczas literatury w polskojęzycznym piśmiennictwie, niewątpliwie zasługiwałaby na próbę kompleksowego spojrzenia na ich obecność w panoramie eklezjalnej Kościoła katolickiego w Rzeczypospolitej Obojga Narodów. W gronie postaci, do których odnoszą się poniższe świadectwa, byli to: Kryspin Cieszkowski, Jerzy Maria Lascaris, Tomasz Nowiński, Józef Pawłowski, Antoni Bartłomiej Raczyński i Łukasz Krzysztof Wielewiejski vel Wielowiejski, a początkowo również Ludwik Józef de Mathy i Marcin Siemieński, z których pierwszy sufraganem poznańskim został dopiero w r. 1795, natomiast drugi na sufraganię gnieźnieńską postąpił dopiero w r. 1823. W odniesieniu do wymienionego wyżej A.B. Raczyńskiego, w stosownej suplice z daty: Ciążeń, 20 VI 1808, adresowanej do papieża Piusa VII, arcybiskup gnieźnieński Ignacy Raczyński w sposób następujący uzasadniał wniosek o promocję do godności biskupiej ówczesnego opata lądzkiego: „Quae praedecessores Sanctitati Vestrae Summi Pontifices, meos antecedaneos atque hanc archidiaecesim Gnesnensem confovebant gratia, qui illius latitudine ac ecclesiarum numerositate attenta, praeter suffraganeos, alios titulares episcopos in partibus ex religiosis etiam ordinibus recommendatos crearent, quales ultimis temporibus fuerunt: Reverendissimus Przedwojewski ex Ordine S. Francisci, Bolinensis, Kozierowski, Adratensis, et Kosmowski, Martyropolitanus, ambo ex Ordine S. Augustini Canonicorum Regularium Lateranensium nuncupatum, pro eodem ego gratia ad Sanctam Sedem Apostolicam supplex recurro, utque Vestra Sanctitas, attentis infrascriptis, episcopatum in partibus Religiosissimo in Christo Bartholomaeo Antonio Raczynski, Ordinis Cisterciensium abbati claustrali monasterii Landensis, in archidiaecesi Gnesnensi impertiti dignetur, provolutus ad pedes Sanctitatis Vestrae supplico" (Archivio Segreto Vatiano, Indice 845, k. 749r - całość, k. 749r-v/751r-v). Podobnego charakteru biskupami bez «przyporządkowania» byli poniekąd też ci «regularni» sufragani, którzy złożyli rezygnację z piastowanej funkcji i następnie pozostawali czynni nadal - tyle, że na zupełnie innym terenie, jak np. eks-sufragan chełmski Dominik Kiełczewski na gruncie krakowskim czy ekssufragan żmudzki Antonin Malinowski (dominikanin) na gruncie warszawskim (podobnie tamże eks-sufragan kijowski Franciszek Remigiusz Zambrzycki). 
$* * * * *$

\section{SKRÓTY ARCHIWALNE}

AAGn - Archiwum Archidiecezjalne w Gnieźnie

AAPrzem - Archiwum Archidiecezjalne w Przemyślu

AAPzn - Archiwum Archidiecezjalne w Poznaniu

AAWO - Archiwum Archidiecezji Warmińskiej w Olsztynie

ADPelp - Archiwum Diecezjalne w Pelplinie

ADPł - Archiwum Diecezjalne w Płocku

ADWł - Archiwum Diecezjalne we Włocławku

AGAD - Archiwum Główne Akt Dawnych w Warszawie

AJG - Archiwum OO. Paulinów w Częstochowie na Jasnej Górze

AKapMK - Archiwum Kapituły Metropolitalnej w Krakowie na Wawelu

AKMK - Archiwum Kurii Metropolitalnej w Krakowie

APBKr - Archiwum Prowincji OO. Bernardynów w Krakowie

ASPF - Archivio Storico «De Propaganda Fide», Rzym

ASV - Archivio Segreto Vaticano, Rzym

BN - Biblioteka Narodowa w Warszawie

CVIA - Lietuvos Centrinis Valstibinis Istorijos Archyvas, Wilno

Ossolineum - Zakład Narodowy im. Ossolińskich we Wrocławiu

\section{SKRÓTY BIBLIOGRAFICZNE}

Chodyński - S. Chodyński, Biskupi sufragani włocławscy, Włocławek 1906

Combaluzier - F. Combaluzier, Sacres épiscopaux à Rome de 1565 à 1662, „Sacris Erudiri" 18 (1967-1968), s. 120-305

Dola (I) - K. Dola, Katalog arcybiskupów i biskupów rezydencjalnych metropolii i diecezji polskich obrządku rzymskokatolickiego do czasów współczesnych, [w:] Historia Kościoła w Polsce, pod red. B. Kumora i Z. Obertyńskiego, t. 2 cz. 2, Poznań - Warszawa 1979, s. 255-303

Dola (II) - K. Dola, Katalog arcybiskupów i biskupów rezydencjalnych eparchii polskich obrzadku grecko-unickiego od unii brzeskiej (1596) do roku 1945, [w:] j.w., s. 304-311

Frydrychowicz - R. Frydrychowicz, Die Culmer Weihbischöfe, Danzig 1905

Korytkowski - J. Korytkowski, Prałaci i kanonicy katedry metropolitalnej gnieźnieńskiej od roku 1000 aż do dni naszych, t. 1-4, Gniezno 1883

Nitecki - P. Nitecki, Biskupi Kościoła w Polsce w latach 965-1999. Słownik biograficzny, Warszawa 2000

Nowacki - J. Nowacki, Dzieje archidiecezji poznańskiej, t. 2 - Archidiecezja poznańska w granicach historycznych i jej ustrój, Poznań 1964

Pawelec - W. F. Pawelec, Biskupstwo chetmskie (szkic historyczny), cz. [6]-[7], „Wiadomości Diecezjalne Lubelskie”, 16 (1934) nr 11, s. 386-400; 17 (1935) nr 1, s. $16-28$ 
Polonica - K.R. Prokop, Polonica z drugiej połowy XVII oraz z XVIII i XIX w. $w$ zbiorze "Iuramenta fidelitatis et Professiones fidei» z Archivio Segreto Vaticano (ASV), „Archiwa, Biblioteki i Muzea Kościelne” 93 (2010), s. 211$-258$

Przybyszewski - B. Przybyszewski, Katalog kanoników krakowskiej kapituły katedralnej w XVIII wieku, Kraków 2009

Sarna - W. Sarna, Biskupi przemyscy obrządu łacińskiego, t. 1-2, Przemyś1 1902$-1910$

Szostkiewicz - Z. Szostkiewicz, Katalog biskupów obrządku łacińskiego przedrozbiorowej Polski, [w:] Sacrum Poloniae Millenium. Rozprawy - Szkice Materiaty historyczne, t. 1, Rzym 1954, s. 391-608

Wiadomości - K. R. Prokop, Wiadomości do biografii biskupów oraz opatów i ksień z ziem Rzeczypospolitej Obojga Narodów z osiemnastowiecznej prasy warszawskiej doby saskiej i stanisławowskiej (1729-1795), „Archiwa, Biblioteki i Muzea Kościelne" 86 (2006), s. 287-329

$* * * * *$

Antoni (syn Mikołaja) biskup (Gniezno)

sakra 5 VIII $1470\left(\right.$ niedziela) $\bullet$ Rzym ${ }^{4}$

ASV, Camera Apostolica, Libri Formatarum 5, k. 27v (Munus consecrationis pro Domino Antonio, electo episcopo Naturensi)

Universis et singulis [notum facimus], quod Reverendus in Christo Pater Dominus Jacobus, episcopus Sancti Angeli de Lombardis, ex commissione nostra de mandato Sanctissimi Domini nostri Papae, nobis super hoc oraculo vive vocis facto, et consilio Reverendorum Patrum Dominorum Vianensis, Rhotomagensis, Bononiensis, eiusdem Domini nostri Papae ${ }^{\mathrm{a}-}[\ldots]^{\mathrm{a}}$ et religiosorum dominorum de Camera, die quinta praesentis mensis Augusti, in ecclesia Beatae Mariae de Minerva in Urbe, assistentibus sibi Reverendis Dominis in Christo Patribus Dominis Castano et Brunatensi episcopis, in Romana Curia residentibus, Reverendo Patri Domino Antonio, electo episcopo Naturensi, munus consecrationis Catholicis episcopis impendi solitum et consuetum, intra missarum solemnia, rite etc. impendit et eum consecravit. [...] Datum Romae, in Palatio Apostolico apud Sanctum Petrum, in Camera Apostolica, anno Domini MCCCCLXX ${ }^{\mathrm{mo}}$, indictione III $\stackrel{a}{\text {, die }}$

a-a tekst nieczytelny

${ }^{4}$ Por. C. Cenci, Documenta Vaticana ad franciscales spectantia ann. 1385-1492, cz. 5 - 14581471, „Archivum Franciscanum Historicum” 94 (2001) z. 1-4, s. 139; K.R. Prokop, Biskupi pomocniczy $w$ diecezjach polskich $w$ dobie przedtrydenckiej (2. pot. XIII-1. pot. XVI w.), Kraków 2002, s. 196. Zob. także Szostkiewicz, s. 407; Nitecki, kol. 11. 
ipso VIII ${ }^{a}$ dictae mensis Augusti, pontificatus Sanctissimi Domini Pauli Divina providentia Papae secundo anno sexto.

\section{2}

Ankwicz Andrzej Alojzy arcybiskup (Lwów)

sakra 15 VIII 1815 (wtorek) • Otomuniec ${ }^{5}$

ASV, Archivio Concistoriale, Processus Consistorialis, vol. 233, k. 310r.

Infrascriptus auctoritate archiepiscopali testor, Reverendissimum ac Illustrissimum Dominum Andream Aloisium Imperii comitem Ankwicz de Poslavice, metropolitanae ecclesiae Olomucensis canonicum capitularem et [...] denominatum archiepiscopum Leopoliensem [...], in ecclesia huiata metropolitana ad S. Wenceslaum, decima quinta mensis Augusti anni millesimi octingentesimi decimi quinti, iuxta ritum in Pontificali praescriptum, ab Eminentissimo et Reverendissimo Celsitudine Sua Domino Maria Thaddaeo, archiepiscopo Olomucensi, assistentibus Excellentissimo ac Reverendissimo Domino Francisco comite Migazzi, metropolitanae ecclesiae Olomucensis decano capitulari infulato, et Excellentissimo ac Reverendissimo Domino Weichardo comite a Trautmansdorf, eiusdem ecclesiae infulato praeposito, in archiepiscopum Leopoliensem consecratum fuisse [...]. Olomutii Moravorum, 26. Julii 1833. Franciscus Losserth, notarius archiepiscopalis iuratus, metropolitanae ecclesiae Olomucensis sacrista minor et eiusdem ecclesiae parrochialis administrator.

\section{3}

Arcemberski Walenty Maciej biskup (Kijów)

sakra 28 VII 1715 (niedziela) • Warszawa

AGAD, Dziat VI, II-79, k. 121r

[Dnia] 28. Julii [1715] była konsekracya Jmci Xiędza biskupa kijowskiego, u teatynów [w Warszawie], ktorey y Krol Jegomość asystował. Konsekrował Jmć Xiądz nuncyusz in assistentia Jmć Xiędza Szeniawskiego [sic!], biskupa kujawskiego, y Bokuma, przemyskiego, podkanclerzego koronnego. Baryłkę jedną niósł Jmć Pan Mniszech, marszałek wielki koronny, drugą ja [autorem zapiski Karol Stanistaw Radziwitt]. Chleby nieśli Jmć Pan Prependowski [sic!], podskarbi wielki koronny, y Jmć Pan Dönhoff, hetman polny Wielkiego Księstwa Litew-

\footnotetext{
${ }^{5}$ Por. Polonica, s. 163, nr 1 (również, nr 2); J. Krętosz, Archidiecezja lwowska obrządku łacińskiego w okresie józefinizmu (1772-1815), Katowice 1996, s. 61; Dola (I), s. 278, nr 28; Nitecki, kol. 10.

${ }^{6}$ Por. Polonica, s. 163, nr 3. Zob. także Szostkiewicz, s. 408; Dola (I), s. 271, nr 32; Nitecki, kol. 11.
} 
skiego. Świece nieśli Jmć Pan Ossolinski, podskarbi nadworny koronny, y Jmć Pan Bielinski, cześnik. Tamże nuncyusz częstował krola y nas.

\section{4}

Bajkowski (Baykowski) Jan biskup (Poznań) $\quad$ sakra 1 V 1627 (sobota) • Rzym ${ }^{7}$

ASV, Miscellanea, Armadia XIII 33, k. 179r [177r]

Feria $6^{\mathrm{a}}$, die ultima Aprilis anno 1627, [...] Reverendus Dominus, Dominus Joannes Baikowski, electus Ecclesiae Ennensis, suffraganeus Posnaniensis, [...] praestitit fidelitatis debitae solitum iuramentum in manibus Illustrissimi et Reverendissimi Domini Hippoliti, Sancti Angeli in Foro Piscium S.R.E. diaconi cardinalis, Aldobrandini nuncupati, praesentibus ibidem Illustrissimo Domino Fratre Silvestro Scotto, equite Hierosolymitano, et Admodum Reverendo Domino Curtio Manelo, testes adhibitis.

Sabbatho, die prima mensis Maii, in festo Sanctorum Apostolorum Philippi et Jacobi anno 1627, [...] Illustrissimus et Reverendissimus in Christo Pater et Dominus, Dominus Cosma, tituli S. Pancratii S.R.E. presbyter cardinalis, de Torres nuncupatus, vive vocis oraculo, Romae, in Basilica Sanctae Mariae Maioris, assistentibus sibi Reverendis in Christo Patribus Dominis Joanne Mattheo, archiepiscopo Iconiensi, et Germanico Mantica, episcopo Famagustano, consecravit in episcopum et pastorem Ecclesiae titularis Ennensis Reverendissimum Dominum Joannem Baikowski [...], praesentibus ibidem Admodum Reverendo Domino Alessandro Bucc ${ }^{\mathrm{a}-}\left[\mathrm{io}^{-\mathrm{a}}\right.$, Spoletanensis dioecesis, et Illustrissimo Domino Angelo Cospio, praefati Illustrissimi et Reverendissimi Domini cardinalis familiari, testibus ad praemissa adhibitis atque vocatis.

Bardziński Ignacy Nepomucen biskup (Gniezno)

sakra 2 VII 1809 (niedziela) • Ciążeñ

AAGn, ACons D 7, s. 260 (Testimonium consecrationis episcopi Satalensis Illustrissimi Bardziński)

[Nos] Ignatius comes Nałęcz de Małoszyn et Raczyno Raczyński, princeps archiepiscopus Gnesnensis etc., [...] notum facimus et attestamur, quia nos [...] munus consecrationis Illustrissimi, Reverendissimi Ignatii Bardziński, electi epi-

a-a urwany brzeg karty.

${ }^{7}$ Por. Nowacki, t. 2, s. 187, nr 21. Zob. także Szostkiewicz, s. 409; Nitecki, kol. 22.

${ }^{8}$ Por. Polonica, s. 164-165, nr 10; Korytkowski, t. 1, s. 33. Zob. także Szostkiewicz, s. 410; Nitecki, kol. 20. 
scopi Satalensis, suffraganei, vicarii in spiritualibus et officialis nostri generalis Gnesnensis, recepto prius ab eodem [...] fidelitatis iuramento, in ecclesia parochiali Ciążynensi, de nostra provincia Gnesnensi existente, Dominica sexta post Pentecosten, quae fuit dies secunda mensis Julii anni currentis millesimi octingentesimi noni, [...] explevimus, Illustrissimis, Reverendissimis Antonio Raczyński, electo episcopo Hetaloniensi, Ordinis Cisterciensis Landensi, Emiliano Kosiński, Ordinis S. Benedicti et S. Stanislai equite Mogilnensi, abbatibus, loco episcoporum, vi facultatis apostolicae [...] huiusmodi consecrationi assistentibus.

\section{6}

Bedliński Stanisław biskup (Łuck)

sakra 6 II 1684 (niedziela) $・$ Kraków $^{9}$

AKMK, LOrd 5, k. 155r

Anno Domini 1684. Perillustris et Reverendissimus Dominus, Dominus Nicolaus Oborski, Dei et Apostolicae Sedis gratia episcopus Laodicensis, suffraganeus [...] Cracoviensis, ipsa Dominica Sexagesimae, quae fuit dies sexta Februarii, consecravit in ecclesia S. Martini, monialium Cracoviae, Perillustrem et Reverendissimum Dominum Stanislaum Bedlinski, episcopum Caesariopolitanum, suffraganeum Luceoriensem.

\section{7}

Benistawski Jan biskup (Mohylów)

sakra 8 II 1784 (niedziela) • Sankt Petersburg ${ }^{10}$

ASPF, Scritture riferite nei Congressi. Moscovia-Polonia-Ruteni, vol. 15, k. 320v$321 r$ (poświadczenie notarialne na rękopiśmiennej formule iuramentum fidelitatis, dokonane przez notariusza apostolica auctoritate Jacobo Massę, sekretarza nuncjusza G.A. Archettiego)

Omnibus et singulis [...] fidem facio et attestor, [...] quod anno a Nativitate Domini Nostri Jesu Christi millesimo septingentesimo quarto, die vero Dominica 28. Januarii iuxta vetus calendarium, 8. vero Februarii iuxta Gregorianum, [...] constitutus personaliter Illustrissimus et Reverendissimus Dominus Joannes Benislawski, episcopus Gadarensis, coram Illustrissimo, Excellentissimo ac Reverendissimo Domino Joanne Andrea Archetti, archiepiscopo Chalcedonensi, in Regno Poloniae nuntio et apud [k. 321r] Augustissimam Catharinam II., totius Russiae imperatricem, apostolico oratore, publice in actu eius consecrationis in ecclesia catholica Petropolitana solemniter habitae, [...] iuramentum fidelitatis de verbo

\footnotetext{
${ }^{9}$ Zob. Szostkiewicz, s. 412; Nitecki, kol. 23.

${ }^{10}$ Por. Wiadomości, s. 296 (tamże przyp. 15). Zob. także Nitecki, kol. 25.
} 
ad verbum $[\ldots]$ in manibus eiusdem Illustrissimi, Excellentissimi et Reverendissimi domini nuntii et oratorii apostolici praestitit.

ASV, Segreteria di Stato. Polonia, Add. 19, b.p. (list arcybiskupa G.A. Archettiego do Sekretariatu Stanu Stolicy Apostolskiej z daty: Sankt Petersburg, 6 II [26 I st.st.] 1784)

Dopodomani 8 Febraro/28 Gennaro [1784], giorno in cui ricorre nel corrente anno per ambedue gli stili la Domenica di Settuagesima, farò la funzione di consacrar vescovo il prevosto Benislawski, che in vigore delle speciali facoltà, compartitemi dal Santo Padre, ho già promosso al vescovado Gadarense. Avrò per vescovi assistenti il nuovo arcivescovo di Mohylovia e Monsignor Powslowski, suffraganeo di Livonia. Mi occupo io stesso a preparare e disporre tutto ciò, che è necessario per una si augusta funzione e per istruire nelle sagre cerimonie, che occorrono i sacerdoti di questa chiesa cattolica, che non hanno mai veduto, nonché assisito a consagrazioni vescovi.

ASV, Segreteria di Stato. Polonia, Add. 19, b.p. (list arcybiskupa G.A. Archettiego do Kurii Rzymskiej z daty: Sankt Petersburg, 13 II 1784)

Nel dì 28 Gennaro vecchio stile e 8 Febraro [1784] secondo il Calendario Gregoriano cadendo la Domenica di Settuagesima consagraì vescovo in questa magnifica chiesa cattolica il preposto Benislawski, eletto Gadarense. Col mio passato di spaccio feci a Vostra Eminenza palese la mia lusinga di esequire in tal giorno questa sagra funzione; oggi ho l'onore di annunziarne l'esecuzione. Fu da me cantata la messa solenne, e Monsignor arcivescovo di Mohilovia ed il vescovo di Alalia, suffraganeo di Livonia, furono i vescovi assistenti alla consagrazione. Oltre il grandissimo concorso tutti quanti i ministri esteri cattolici intervennero alla sagra cerimonia, che anzi sei de' medesimi si fecer pregio di recare avanti l'altare le solite offerte, che quindi dal consagrato si presentano al consagrante, cioè il Signor conte di Cobenzl, ministro cesareo, il Signor Deboli, ministro dello Re e Repubblica di Polonia, il Signor duca di Serra Capriola, ministro di Napoli, il Signor marchese Parella di Sardegna, Monsieur d'Azanza, incaricato del Re Cattolico, e Monsignor d'Oliveira, incaricato di Sua Maestà la Regina di Portogallo. Invio copia dell'atto, ossia istrumento, che alcuni giorni prima della sua consagrazione venne da me spedito e consegnato al preposto Benislawski.

Betański Antoni Wacław biskup (Przemyśl) sakra 19 VIII 1781 (niedziela) • Stara Wieś ${ }^{11}$

${ }^{11}$ Por. Sarna, t. 2, s. 496. Zob. także Dola (I), s. 291, nr 54; Nitecki, kol. 29. 
AAPrzem, 146, s. 68-69.

Anno Domini millesimo septingentesimo octuagesimo primo, Dominica undecima post Pentecosten, quae fuit dies decima nona mensis Augusti, Illustrissimus et Reverendissimus Dominus Josephus Thaddaeus de Kiekrz Kierski, episcopus Premisliensis, consecravit Illustrissimum et Reverendissimum Antonium Venceslaum Betanski in episcopum Troadensem quam coadiutorem episcopatus Premisliensis. Assistentibus ad mentem bullae Illustrissimo et Reverendissimo Melchiore Joanne Kochnowski, episcopo Dyonisyensi, suffraganeo Chełmensi, et Michaele Romano [s. 69] Sierakowski, episcopo Prussensi, suffraganeo Premisliensi, intra missarum solemnia in ecclesia monachorum Sancti Pauli Primi Eremitae in villa Starawies, servatis servandis, adhibitis adhibendis.

AAPrzem, 146, s. 265(217)

Illustrissimus et Reverendissimus Dominus Michaël de Antiqua Sierakow Sierakowski, Dei et Apostolicae Sedis gratia episcopus Prussensis, coadiutor decanus, canonicus cathedralis, suffraganeus, vicarius in spiritualibus et officialis generalis Premisliensis, die 19. mensis Augusti anno 1781 $\frac{\mathrm{mo}}{\text {, }}$ Dominica 11. post Penthecosten, sub actu consecrationis in ecclesia religiosorum Ordinis Sancti Pauli Primi Eremitae in Stara Wies electi in episcopum Troadensem Illustrissimi et Reverendissimi Antoni Venceslai Betański, coadiutoris cum successione episcopatus Premisliensis, ab Illustrissimo et Reverendissimo Domino Josepho Thaddeo de Kiekrz Kierski, episcopo Premisliensi, equite Aquilae Albae, vigore literarum apostolicarum consecratore peractae, assistente a dexteris Illustrissimo et Reverendissimo Melchiore Kochnowski, episcopo Dionisiensi, suffraganeo et officiali generali Chełmensi, munus assistentis a sinistris obivit.

\section{9}

Brodziszewski Wojciech Anzelm biskup (Gniezno)

sakra 5 IX 1841 (niedziela) • Poznań ${ }^{12}$

AAGn, ACap, B 82, k. $2 r$

Anno Domini millesimo octingentesimo quadragesimo primo. [...] Posnaniae, die quinta mensis Septembris, quae fuit Dominica decima quarta post Pentecostes, intra missarum solemnia, in ecclesia cathedrali Posnaniensi, praesente toto capitulo ac clero cathedrali, necnon quam maximo concursu populi Christiani de civitate et confinis congregato, fui consecratus in episcopum Themiscyrensem in partibus infidelium et in suffraganeum Ecclesiae cathedralis Gnesnensis per Celsissimum Martinum Dunin, archiepiscopum Gnesnensem et Posnaniensem, in assistentia Reverendissimorum duorum dignitariorum: Edvardi Markowski, abbatis

${ }^{12}$ Por. Korytkowski, t. 1, s. 81. Zob. także Nitecki, kol. 40-41. 
Canonicorum Regularium Trzemesznensium, et Francisci Xaverii Salmonski, praepositi infulati monialium Praemonstratensium in Strzelno, qui duo ex expressa dispensatione apostolica in locum duorum consecratorum episcoporum substituti erant. Ego ipse Adalbertus Anselmus Brodziszewski, episcopus Themiscyrensis, suffraganeus et canonicus Gnesnensis.

Brzostowski Konstanty Kazimierz biskup (Smoleńsk - Wilno) sakra 15 VII 1685 (niedziela) $・$ Kielce $^{13}$

AKMK, AEp 69, k. 170v: Solis XV. Junii 1685, Kielciis. Consecratio episcopi Smolenscensis [sam nagłówek, bez następującej po nim zapiski o sakrze, na która pozostawiono $w$ księdze puste miejsce - na pót strony - do późniejszego uzupetnienia, co jednak nie nastapiło]

Anno Domini 1661, Dominica tertia post Epiphaniam Domini, quae fuit dies 23. Januarii, consecratio pro episcopatu Argivensi et suffraganeatu Culmesni et Pomeraniae facta est per Illustrissimum ac Reverendissimum Dominum Casimirum Florianum ducem in Clevan Czartoryski, Dei Sedisque Apostolicae gratia episcopum Vladislaviensem et Pomeraniae, Perillustris ac Reverendissimi Domini Mathiae Bystram, archidiaconi et officialis generalis Culmensis, assistentibus duobus et adiuvantibus eundem Illustrissimum et Reverendissimum Dominum, [nempe] Stanislao Domaniewski, episcopo Margaritensi, suffraganeo Vladislaviensi et Pomeraniae, deputato iudice Tribunali Regni, et Stanislao Święcicki, episcopo Spigacensi, suffraganeo Samogitiae, decano Vladislaviensi.

\section{2}

Charbicki Krzysztof biskup (Włocławek)

sakra 12 VIII 1635 (niedziela) • Wolbórz ${ }^{15}$

${ }^{13}$ Por. T. Długosz, Dzieje diecezji smoleńskiej, Lwów 1937, s. 77, nr 8. Zob. także Szostkiewicz, s. 421; Dola (I), s. 293, nr 8; Nitecki, kol. 43.

${ }^{14}$ Por. Frydrychowicz, s. 12-13, nr 3. Zob. także Szostkiewicz, s. 422; Nitecki, kol. 46.

${ }^{15}$ Por. Chodyński, s. 51. Zob. także Szostkiewicz, s. 423; Nitecki, kol. 49-50. 
ADWt, 2-ABKP 20(40a), s. 310-313.

Anno Domini millesimo sexcentesimo trigesimo quinto, die Dominica, quae fuit dies duodecima mensis Augusti, Volboriae. Coram Illustrissimo et Reverendissimo Domino Mathia Łubienski, Dei et Apostolicae Sedis gratia episcopo Vladislaviensi, constitutus personaliter Perillustris et Reverendissimus Dominus Christophorus Charbicki, Dei et eiusdem Sedis Apostolicae gratia episcopus Margaritensis, per Sedem Apostolicam pro suffraganeatu ad ecclesiam cathedralem Vladislaviensem ad nominationem et electionem memorati Illustrissimi Domini episcopi Vladislaviensis specialiter provisus, tenens et habens suis in manibus praefatis provisionis ad suprapraefatum episcopatum in forma bullarum [...] una cum forma iuramenti ad effectum consecrationis sibi in eodem rescripto transmissa ipsisque exhibitis ac earum contentis inhaerendo, eundem suprascriptum Illustrissimum et Reverendissimum Dominum episcopum debita cum instantia requisivit, petens per Suam Illustrissimam Celsitudinem ad executionem iuxta vim ac tenorem dicti diplomatis apostolici procedi seque in episcopum Margaritensem consecrari [...]. [s. 312] Et Illustrissimus ac Reverendissimus Dominus episcopus praefatus [Maciej Łubieński], litteris praedictis cum ea qua decet reverentia, etiam cum osculo susceptis lectisque ac bene intellectis sese ad executionem praedictarum litterarum apostolicarum libenter processurum obtulit et earum contentis inhaerendo ad praefatum iuramentum praenominatum Reverendissimum Dominum episcopum Margaritensem suum [s. 313] nominatum ac electum provisumque apostolicum, iuxta formam [...] praescriptam admisit, illudque in manibus suis, prout iuris erat, recepti et manu propria praenominati Reverendissimi Domini provisi subscribe fecit $[\ldots]$ ac eundem infra missarum solemnia $[\ldots]$ in ecclesia collegiata Volboriensi, dioecesis Gnesnensis, consecravit, cum assistentia Illustrissimorum et Reverendissimorum Dominorum Stanislai Łubienski, Dei et Apostolicae Sedis gratia episcopi Plocensis, et Stanislai Starczewski, Dei et eiusdem Sedis gratia episcopi Lacedemoniensis, suffraganei et abbatis Plocensis. Cuius iuramenti receptionis et consecrationis actum ad acta sua episcopalia connotari, ipsorumque exempla inseri et copias extradi quando opus fierit, ut ad Curiam Romanam transmittantur mandavit.

\section{3}

Chotek Ferdynand Maria arcybiskup (Otomuniec - Tarnów - Ołomuniec)
sakra 1 VI $1817\left(\right.$ niedziela) $・$ Kromieryż $\dot{z}^{16}$

ASV, Archivio Concistoriale, Processus Consistorialis, vol. 232, k. 349r

${ }^{16}$ Por. Polonica, s. 166, nr 21 (również s. 167, nr 22); B. Kumor, Diecezja tarnowska. Dzieje ustroju i organizacji 1786-1985, Kraków 1985, s. 258. Zob. także Nitecki, kol. 52-53; A. Zelenka, Die Wappen der böhmischen und mährischen Bischöfe, Regensburg 1979, s. 255. 


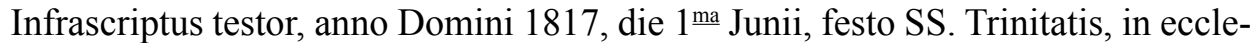
sia collegiata Eremsiriensi a Reverendissimo et Illustrissimo Domino archiepiscopo Olomucensi Maria Thaddaeo comite a Trautmansdorff consecratum fuisse episcopum Ptolemaidensem in partibus infidelium Reverendissimum et Illustrissimum Dominum Ferdinandum Mariam comitem a Chotek, assistentibus de expressa apostolica licentia duobus praelatis benedictis et infulatis, nempe Domino Christophoro comite a Migazzi, decano, et Domino Waichardo comite a Trautmansdorff, praeposito capituli metropolitanae ecclesiae Olomucensis. Datum Eremsirii, in aedibus praeposituralibus, die 15. Februarii 1831. Rudolphus [Franciscus] liber baro a Thysebaert, canonicus Olomucensis et collegiatae ecclesiae ad S. Mauritii praepositus.

\section{4}

Cieciszowski Kasper Kazimierz arcybiskup (Kijów - Łuck/Żytomierz - Mohylów) sakra $8 \times 1775$ (niedziela) $\bullet$ Warszawa ${ }^{17}$

ASPF, Scritture riferite nei Congressi. Moscovia - Polonia - Ruteni, vol. 17, k. 483r-484r (Ingrossatio testimoni super consecratione in episcopum Tebestanensem Illustrissimi, Excellentissimi et Reverendissimi Domini Gasparis Cieciszowski, coadiutoris episcopatus Kijoviensis et Czerniechoviensis)

[Nos] Andreas Stanislaus Kostka Młodziejowski, Dei et Apostolicae Sedis gratia episcopus Posnaniensis [k. 483v] et Varsaviensis, supremus Regni cancellarius, Ordinis Aquilae Albae et S. Stanislai eques, universis et singulis [...] significamus [...], [quod] anno Domini millesimo septingentesimo septuagesimo quinto, Dominica octava post Pentecosten, quae fuit dies octava mensis Octobris, hic Varsaviae, in ecclesia collegiata regia Varsaviensi, assistentibus nobis Illustrissimis et Reverendissimis Dominis Antonio Okęcki, Chelmensi, et Gabriele Wodzynski, Smolensceni, episcopis, recepto prius a [Gaspare Casimiro Cieciszowski] solito fidelitatis iuramento iuxta $[k .484 r]$ formam una cum bullis transmissam, servatisque omnibus solemnitatibus in Pontificali Romano descriptis, munus consecrationis ipsi impendimus. [...] Datum Varsaviae, die decima quarta Octobris millesimo septingentesimo septuagesimo quinto.

\section{5}

Cieszkowski Kryspin biskup ([Lwów])

sakra 18 IV 1773 (niedziela) $\bullet$ Lwów $w^{18}$

${ }^{17}$ Por. Wiadomości, s. 297 (tamże przyp. 19); J. Wasilewski, Arcybiskupi i administratorowie archidiecezji mohylowskiej, Pińsk 1930, s. 7. Zob. także Szostkiewicz, s. 426; Dola (I), nr 39, s. 271; Nitecki, kol. 55-56; Polonica, nr 23, s. 167.

${ }^{18}$ Por. J. Krętosz, Organizacja archidiecezji lwowskiej obrządku łacińskiego od XV wieku do 1772 roku, Lublin 1986, s. 104, nr 12. Zob. także Szostkiewicz, s. 427; Nitecki, kol. 57. 
AGAD, Dział III, zespót 396; 247, k. 73r

Anno Domini 1773, die 18. Aprilis, quae fuit Dominica in Albis Conductus Paschae, in ecclesia metropolitana Leopoliensi, [archiepiscopus Venceslaus Hieronymus Sierakowski] consecravit solemni ritu Illustrissimum et Reverendissimum Crispinum Cieszkowski, custodem ecclesiae metropolitanae et officialem generalem Leopoliensem, ad episcopatum Nyssensem, assistentibus sibi quatuor infulatis, scilicet Illustrissimo Jacobo Augustynowicz, archiepiscopo Leopoliensi ritus Armenorum, Illustrissimo Samuele Głowinski, episcopo Hebronensi, suffraganeo Leopoliensi, Illustrissimo Raymundo Jezierski, episcopo Baccoviensi, et Illustrissimo Jacobo Tumanowicz, episcopo Camacensi, coadiutore suprascripti archiepiscopi ritus Armenorum.

\section{6}

Czapski Walenty Aleksander biskup (Przemyśl - Włocławek) sakra 16 VI 1737 (niedziela) $・$ Radom $^{19}$

AKapMK, LA 36, s. 27

Anno Domini 1737, die 16. mensis Junii, Radomiae, in ecclesia monialium Sancti Benedicti, Illustrissimus et Reverendissimus Dominus, Dominus Joannes Alexander in Lipe Lipski, episcopus Cracoviensis, dux Severiae, consecravit Illustrissimum et Reverendissimum Dominum, Dominum Czapski, episcopum Praemisliensem.

AAPrzem, Archiwum Kapituly, X, s. 712

Capitulum generale ordinarium in crastino festi Nativitatis S. Joannis Baptistae anno $1737^{\mathrm{mo}}[\ldots]$ fuit legitime celebratum, existentibus tunc ad assistentiam Illustrissimo ac Reverendissimo Domino, Domino Valentino Alexandro Czapski, Dei et Apostolicae Sedis gratia episcopo Premisliensi, pro consecratione sua Radomiam transeunti, Illustrissimo ac Reverendissimo Domino Andrea Pruski, suffraganeo et praeposito, Perillustribus autem et Admodum Reverendis Joanne Cantii Salatii [Sałacki] U.J.D., Valentino Pruski, canonicis cathedralis Premisliensibus, a capitulo deputatis.

${ }^{19}$ Por. Sarna, t. 2, s. 423. Zob. także Szostkiewicz, s. 429; Dola (I), s. 291, nr 48; Nitecki, kol. 62-63; Wiadomości, s. 298 (tamże przyp. 22); R. Frydrychowicz, Geschichte der Cistercienserabtei Pelplin und ihrer Bau- und Kunstdenkmäler, Düsseldorf 1906, s. 112-114, nr 36. 


\section{7}

Czermiński Łukasz Jacek biskup (Przemyśl)
sakra 25 VIII 1715 (niedziela) $・$ Warszawa ${ }^{20}$

AGAD, Dziat VI, II-79, k. $121 r$

[Dnia] 25. Augusti [1715], po mszy i śniadaniu [w Piaseczynie], powróciłem [autorem zapiski Karol Stanisław Radziwitt] do Warszawy na koniec konsekracyi Jmci Xiędza Czerminskiego, suffragana przemyskiego, u Świętego Krzyża, gdzie nas częstował Jmć Xiądz [biskup] poznański kosztem Jmci Xiędza biskupa przemyskiego.

\section{8}

Czulski Walenty Konstantyn biskup (Chetm/Krasnystaw) sakra 1 VI 1721 (niedziela) $・$ Krasnystaw ${ }^{21}$

AAPrzem, 144, k. 10r

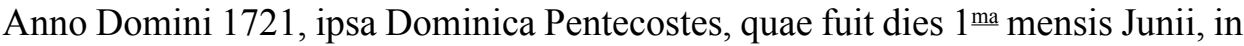
ecclesia cathedrali Chełmensi, Crasnostaviam translata, Illustrissimus, Excellentissimus et Reverendissimus Dominus, Dominus Alexander Antonius de Pleszowice in Przedzel Fredro, Dei et Apostolicae Sedis gratia episcopus Chełmensis, respiciendo merita Reverendissimi Domini Valentini Constantini Czulski, archidiaconi, vicarii in spiritualibus ac officialis generalis Chełmensis, contulit suffraganeatum eundemque, assistentibus ac praesentibus Illustrissimis et Reverendissimis Dominis, Dominis Stephano Rupniewski, Camenecensi, Feliciano Joanne Szaniawski, Capsensi, suffraganeo, archidiacono, vicario in spiritualibus ac officiali generali metropolitano Leopoliensi, Reverendissimo Josepho Lewicki, ritus Graeci unito, episcopis, ac aliis perillustribus, illustrissimis, magnificis et admodum reverendis dominis, consecravit.

\section{9}

Dąbrowski Jan biskup (Poznań) $\quad$ sakra 20 VIII 1843 (niedziela) • Gniezno ${ }^{22}$

AAGn, ACap, B 82, k. 4r-v (Consecratio in episcopum etc. Joannis Dąmbrowski)

[Nos] Anselmus Adalbertus Brodziszewski, miseratione Divina et Sanctae Sedis

${ }^{20}$ Por. Korytkowski, t. 1, s. 187. Zob. także Szostkiewicz, s. 430; Nitecki, kol. 64; Przybyszewski, s. 38.

${ }^{21}$ Por. Pawelec, cz. 7, s. 21, nr 5. Zob. także Szostkiewicz, s. 431; Nitecki, kol. 65.

${ }^{22}$ Por. Polonica, s. 168, nr 28; Nowacki, t. 2, s. 191-192, nr 39. Zob. również Nitecki, kol. 69. 
Apostolicae gratia episcopus Themiscyrensis in partibus infidelium, suffraganeus et canonicus metropolitanus Gnesnensis, universis [...] notum facimus et attestamur, quia nos [...] munus consecrationis Illustrissimi et Reverendissimi Domini Joannis Dąbrowski, canonici metropolitani et consiliarii iudicii prosynodalis Posnaniensis, in episcopum Helenopolitanum in partibus infidelium et suffraganeum Posnaniensem, recepto prius ab eodem, iuxta formam praescriptam, in manibus nostris emisso solito fidelitatis iuramento, in ecclesia metropolitana Gnesnensi, Dominica XI post Pentecosten, quae fuit dies vigesima mensis Augusti anni currentis millesimi octingentesimi quadragesimi tertii, intra ipsa sacrarum missarum sollennia, $[\ldots]$ in episcopum consecravimus, Perillustribus, Reverendissimis Edvardo Markowski, abbate Trzemesnensi, et Francisco Xaverio Salmonski, praeposito infulato Strzelnensi, loco episcoporum consecratorum, vi facultatis apostolicae $[\ldots],[k .4 v]$ ad id specialiter indultae, huiusmodi consecrationi assistentibus.

Dederko Jakub Ignacy biskup (Mińsk) sakra 26 VIII [15 VIII st.st.] 1798 (niedziela) • Połock ${ }^{23}$

ASV, Segreteria di Stato. Polonia, vol. 344 - Add. III, b.p. (list biskupa J.I. Dederki do nuncjusza L. Litty z daty: Połock, 19/30 VIII 1798); tamże, b.p. (list biskupa J.I. Dederki do nuncjusza L. Litty z daty: Mińsk, 17 I 1799: „, Solemnis iuramenti tempore consecrationis meae peracti Vestrae Excellentiae quamvis dudum caruit suo effectu; attamen, quia hoc extra meam benevolam notitiam factum est, nihil in huius delicti suspitione me peccaturum scio")

Consecrationem meam per tres episcopos Polociae peractam esse die 15. huius mensis Augusti [1798] significo Illustrissimae Suae Excellentiae.

ASPF, Scritture riferite nei Congressi. Moscovia - Polonia - Ruteni, vol. 17, k. 520r$521 v$ : ,Iuramentum coram Illustrissimo, Reverendissimo Domino Joanne Benisławski, episcopo Gadarensi, coadiutore archiepiscopatus Mohiloviensis, equite Ordinis S. Stanislai, anno 1798, die 15. Augusti expletum”; tamże, k. 518r-519v i 521v: „Iuramentum praestitum a Jacobo Ignatio Dederko, episcopo Minscensi, in actu consecrationis suae peractae a Joanne Benislawski, episcopo Gadarensi, coadiutore Mohiloviensi"

Iuramentum hoc de verbo ad verbum ab Illustrissimo, Reverendissimo Jacobo Ignatio Dederko, episcopo Minscensi, equite Ordinum Polonorum, tempore consecrationis suae in episcopum Minscensem, praestitum esse testor. Joannes Benisławski, episcopus Gadarensis, coadiutor archiepiscopatus Mohiloviensis, eques Ordinis Sancti Stanislai.

${ }^{23}$ Por. Dola (I), s. 282, nr 1; Nitecki, kol. 70. 


\section{1}

Delamars (De la Mars) Michat biskup (Kamieniec - Chetm/Krasnystaw) sakra 28 I 1725 (niedziela) $\cdot$ Kielce $^{24}$

AKMK, LOrd 8, s. 39

Dominica Septuagesima [1725], quae fuit dies 28. mensis Januarii, Illustrissimus et Reverendissimus Dominus [Constantinus Felicianus Szaniawski, episcopus Cracoviensis], in ecclesia collegiata Kielcensi, consecravit infra missarum solemnia Illustrissimum et Reverendissimum Michaelem De la Mars in episcopum Tricomiensem, suffraganeum Chełmensem, vigore bullarum apostolicarum, cum assistentia Illustrissimorum et Reverendissimorum Felicis Szaniawski, episcopi Capsensis, suffraganei Leopoliensis, nominati Chełmensis, et Bernardi Gostcki [sic!], episcopi Isauriensis, suffraganei Posnaniensis.

\section{2}

Dembowski Antoni Sebastian biskup (Płock - Włocławek) sakra 9 VI 1737 (niedziela) $・$ Warszawa ${ }^{25}$

$A D W t, 2-A B K P$ 44(52 cz. 2), k. $1 v$

Anno Domini 1737, die 9. Junii, to iest w niedzielę świąteczną, byłem [odnosi się do biskupa A.S. Dembowskiego] consecratus na biskupstwo płockie. Consecrator moy był Jmć Xiądz Hozyusz, biskup poznański, conconsecratores Jmć Xiądz Kobielski, biskup kamieniecki, y Jmć Xiądz Rostkowski, biskup filadelfeń[ski], sufragan łucki. Anno Domini 1738, die 6. Maii, feci ingressum ad cathedram Plocensem.

AAPzn, ASO 8, k. [57v].

A.D. 1737, die 9. Junii, quae fuit ipsa Dominica Pentecostes, Varsaviae, in ecclesia collegiata Varsaviensi, consecravit Illustrissimus loci ordinarius [Stanislaus Josephus Hosius, episcopus Posnaniensis], in episcopum Plocensem Illustrissimum et Reverendissimum Dominum Dębowski, in assistentia Illustrissimi Francisci Kobielski, episcopi Kamenecensis, et Illustrissimi Rostkowski, suffraganei Luceoriensis.

${ }^{24}$ Por. Pawelec, cz. 7, s. 22, nr 6; Przybyszewski, s. 41-42. Zob. także Szostkiewicz, s. 432-433; Nitecki, kol. 71.

${ }^{25}$ Por. Wiadomości, s. 298 (tamże przyp. 25). Zob. także Szostkiewicz, s. 433; Dola (I), s. 285, nr 62; Nitecki, kol. 72. 


\section{3}

Dembowski Jan biskup (Wtoctawek) $\quad$ sakra 2 II 1760 (sobota) Smardzewice $^{26}$ ADWt, 2-ABKP 44(52 cz. 2), k. 106v.

Die 2. Februarii 1760 consekrowałem [odnosi się do biskupa Antoniego Sebastiana Dembowskiego] Jmci Xiędza Jana Dembowskiego, episcopum in partibus Lambaesitanum, na sufraganią kujawską, w kościele OO. Franciszkanow apud S. Annam Smarzeviensem. Conconsecratores byli Jmć Xiądz Antoni Ostrowski, biskup inflancki, koadiutor moy, y Jmć Xiądz Marcin Załuski, sufragan płocki.

\section{4}

Dmochowski Kazimierz biskup (Wilno - Mohylów) sakra 11 VII [29 VI st.st.] 1841 (niedziela) • Sankt Petersburg ${ }^{27}$

ASV, Archivio Concistoriale, Processus Consisoriales, vol. 250, k. 832 r.

Ex litteris testimonialibus piae memoriae Illustrissimi, Reverendissimi Domini Ignatii Corvin Pawłowski, archiepiscopi Mohiloviensis [...], liquet eundem Illustrissimum, Reverendissimum Dominum Casimirum Dmochowski a modo laudato archiepiscopo Pawłowski, opem ei ferentibus duobus episcopis ex Regno Poloniae, nimirum Calisiensi Illustrissimo, Reverendissimo Domino Valentino Tomaszewski, et Augustoviensi Illustrissimo, Reverendissimo Domino Paulo Straszyński, Petropoli, in ecclesia parochiali S. Catharinae Virginis et Martyris, die 29. veteri stylis mensis Junii anno Domini 1841, in festo Sanctorum Apostolorum Petri et Pauli, in praesentia cleri saecularis et regularis nec non Christi fidelium in maxima frequentia ad hanc solemnitatem congregatorum, intra missarum solemnia munus consecrationis suscepisse.

25

Dobiński Krzysztof biskup (Gniezno)

sakra 31 VIII 1738 (niedziela) $\bullet$ Lowicz $^{28}$

\footnotetext{
${ }^{26}$ Por. Chodyński, s. 75. Zob. także Szostkiewicz, s. 433; Nitecki, kol. 73; Wiadomości, s. 298-299 (tamże przyp. 26).

${ }^{27}$ Por. Polonica, s. 169, nr 36 (również, nr 37); Wasilewski, Arcybiskupi i administratorowie, s. 50. Zob. także Nitecki, kol. 77.

${ }^{28}$ Por. Korytkowski, t. 1, s. 226, 241-242. Zob. także Szostkiewicz, s. 436; Nitecki, kol. 78; Wiadomości, s. 299; Przybyszewski, s. 45-46; J. Szczepaniak, Duchowieństwo diecezji krakowskiej w XVIII wieku. Studium prozopograficzne, Kraków 2010, s. 574.
} 
AAGn, ACons G II 4, karta tytułowa: „Acta pontificalium exercitiorum Illustrissimi ac Reverendissimi Domini, Domini Christophori Michaelis in Dobnia Dobinski, episcopi Serrensis, suffraganei Gnesnensis, praepositi Calissiensis, decani Loviciensis

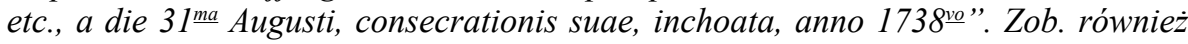
ADPelp, AKKCh, A 16, s. 110 (nr 7).

Dobriolanus Szymon biskup (Mołdawia)

sakra 28 XII 1488 (niedziela) $・$ Rzym $^{29}$

ASV, Camera Apostolica, Libri Formatarum 9, k. $71 v$ (Consecratio episcopi Moldaviensis)

Universis et singulis [notum facimus], [...] quod Reverendus in Christo Pater Dominus Titus [Veltri], episcopus Castrensis, [...] adstantibus duobus aliis episcopis, gratiam et communionem Apostolicae Sedis habentibus, die dato praesentium, in ecclesia Sancti Trifonis de Urbe, Reverendo in Christo Patri Domino Simoni, episcopo Moldaviensi, munus consecrationis episcopalis impendi solitum, solemniter impendit iuxta formam [et consuetudinem Sacrae Romanae Ecclesiae] etc. Datum Romae, in Camera Apostolica, die XXVIII. Decembris 1489, anno quinto ${ }^{30}$.

\section{7}

\section{Dowgiałto Zawisza Stanisław Kazimierz biskup (Inflanty/Wenden) sakra 19 VII 1744 (niedziela) • Warszawa ${ }^{31}$}

AKapMK, LA 36, s. 27-28. Zob. również BN, BOZ 941, s. 389-390 (zapiska z lipca 1744 r.: „Byt w Warszawie konsekrowany suffragan inflantski Dowgiało Zawisza”).

Anno Domini 1744, die 19. Julii, Varsavae, in ecclesia Sanctae Crucis Congregationis Missionariorum, Eminentissimus Dominus [cardinalis Joannes Alexander Lipski, episcopus Cracoviensis], consecravit Illustrissimum et Reverendissimum [s. 28] Dominum Stanislaum Dowgiało Zawisza, episcopum suffraganeum Livoniae. Aderat huic actui Serenissimus et Invictissimus Augustus Tertius,

${ }^{29}$ Zob. Dola (I), s. 292, nr 11; Nitecki, kol. 78.

${ }^{30}$ Zarówno poprzedzające odnośną zapiskę, jak też następujące po niej wpisy pochodzą z roku 1488, bez wątpienia więc chodzi o ten właśnie rok (prowizję na biskupstwo mołdawskie Szymon Dobriolanus uzyskał jeszcze 14 XI 1484 r.), zaś wskazanie na rok 1489 wynika z przyjęcia rachuby a Nativitate (tj. od 25 XII), czyli rozpowszechnionego w średniowieczu stylu Bożego Narodzenia (28 XII 1488 r. był dla notariusza Kamery Apostolskiej już rokiem 1489), zwanego stilus Curiae Romanae. Potwierdza to również formuła datacyjna anno quinto, jako że piąty rok pontyfikatu ówczesnego papieża Innocentego VIII, obranego 29 VIII 1484 r., a koronowanego 12 IX tr., zawierał się w przedziale 12 IX 1488-11 IX 1489 (w odniesieniu do grudnia 1489 r. byłoby zatem anno sexto).

${ }^{31}$ Por. Wiadomości, s. 299. Zob. także Szostkiewicz, s. 439; Nitecki, kol. 81. 
rex Poloniae, cum Serenissima Maria Josepha, regina Poloniae, in assistentia multorum senatorum Regni, inque ingenti distinctorum munerositate.

\section{8}

Dunin Marcin arcybiskup (Gniezno-Poznań)

sakra 10 VII 1831 (niedziela) $\cdot$ Gniezno $^{32}$

AAGn, ACons G II 5, k. 33v-34r

Anno Domini millesimo octingentesimo trigesimo primo, Dominica VII post Pentecosten, quae fuit 10. mensis Julii, ego infracriptus [Martinus Siemieński], episcopus Cyrenensis, suffraganeus Gnesnensis, [...] munus consecrationis Excellentissimi, Reverendissimi Domini Martini de Dunin, electi et confirmati archiepiscopi Gnesnensis et Posnaniensis [...], in ecclesia metropolitana Gnesnensi explevi, Perillustribus [et] Reverendissimis Dominis Caietano Kowalski et Stanislao Gajerowicz, eiusdem ecclesiae metropolitanae canonicis, vi specialis indulti apostolici $[\ldots]$, loco episcoporum huiusmodi consecrationis assistentibus.

\section{AAGn, ACap B 43, s. 230 (Actus consecrationis Celsissimi archiepiscopi Dunin)}

Cum Dominica proxime praeterita, quae fuit 10. mensis currentis [Julii], consecratio Celsissimi, Excellentissimi, Reverendissimi Martini de Dunin, electi et confirmati archiepiscopi Gnesnensis et Posnaniensis, per Illustrissimum Dominum Martinum de Siemieński, episcopum Cyrenensem, suffraganeum Gnesnensem, in hac ecclesia metropolitana [...] explecta sit ac eadem peracta praelibato Celsissimo archiepiscopo pallium impositum sit, proinde illustrissimi, reverendissimi domini [praelati et canonici] actum huiusmodi consecrationis et pallii impositionis hic in actis adnotari mandaverunt.

Działyński Aleksander biskup (Włocławek)

sakra 15 V $1738($ czwartek $) \cdot$ Lowicz $^{33}$

ASV, Archivio Concistoriale, Processus Consistorialis, vol. 123, k. 588v-589v. Zob. również ADPelp, AKKCh, A 16, s. 110 (nr 6)

[Nos] Theodorus Potocki, $[\ldots]$ archiepiscopus Gnesnensis $[\ldots]$, significamus, qualiter Reverendissimus Dominus Alexander Działynski, [...] episcopus Axie-

${ }^{32}$ Por. Polonica, s. 169-170, nr 40. Zob. również Nowacki, t. 2, s. 116-117; Dola (I), s. 265, nr 71; Nitecki, kol. 85.

${ }^{33}$ Por. Chodyński, s. 70-71. Zob. także Szostkiewicz, s. 441; Dola (I), s. 260, nr 33; Nitecki, kol. 88 . 
rensis, suffraganeus Vladislaviensis, in festo Ascensionis Domini Nostri Jesu Christi, die $15^{\text {ta }}$ mensis Maii, anni currentis [1738], in insigni collegiata Łoviciensi a nobis et assistentibus Reverendissimis Culmensi et Varmiensi suffraganeis [...] consecratus est.

ADWt, 2-ABKP 20(40a), s. 602-605 (dokument z daty: Vladislaviae, 20. Junii Anno 1639)

[Nos] Mathias Łubienski, episcopus Vladislaviensis etc., universis et singulis [...] notitiam indubitatam deducimus, quia nos cum debita instantia existentes requisiti ab Illustrissimo et Reverendissimo Domino Gasparo Działynski, electo a Sancta Sede Apostolica de episcopatu Culmensi proviso et ad consecrationem sui in episcopum Culmensem procederemus idque vigore diplomatis apostolici [...]. Nos ea qua decet reverentia ac praevio osculo receptis praefatis literis eisdemque lectis et bene intellectis ad executionem ipsarum libenter nos processuros obtulimus prout assignato die et tempore, videlicet die Dominico SS. Trinitatis, quae fuit dies 19. Junii in anno praesenti millesimo sexcentesimo trigesimo nono, Torunium, ad civitatem eiusdem dioecesis insignem descendendo, ibidem in ecclesia parochiali maiori ex admissione eiusdem Illustrissimi et Reverendissimi Domini Gaspari Działynski, tanquam ordinarii eiusdem dioecesis, inhaerendo contentis praefatarum literarum peragimus [...], intra missarum solemnia, servatis de iure et consuetudine servandis alias iuxta praescriptum Pontificalis Romani consecravimus, [s. 603] adhibitis ad eum actum assistentibus Perillustribus et Admodum Reverendissimis Dominis Stanislao Starczewski, Dei et Apostolicae Sedis gratia episcopo Lacedaemoniensi, suffraganeo et abbate Plocensi, nec non Michaele Działynski, eiusdem Sedis gratia episcopo Hipponensi, suffraganeo Varmiensi abbateque Mogilnensi.

ADPelp, C 13, k. 2r

Illustrissimus ac Reverendissimus Dominus, Dominus Gasparus a Działyn Działynski, decanus Vladislaviensis, a Serenissimo Domino, Domino Vladislao IV $[\ldots]$ rege $[\ldots]$ episcopus Culmensis et Pomesaniae nominatus, per venerabile capitulum Culmense [...] electus et in consistorio Sanctissimi Domini nostri Domini Vrbani, Divina Providentia Papae VIII. [...] tertio nonas Februarii MDCXXXVIII anno de eodem episcopatu provisus et confirmatus [...], ab Illustrissimo et Reverendissimo Domino Matthia Lubinski [sic!], episcopo Vladislaviensi et Pomeraniae, die XIX Junii MDCXXXIX anno in ecclesia parochiali Thorunensi con-

\footnotetext{
${ }^{34}$ Zob. Szostkiewicz, s. 441-442; Dola (I), s. 260, nr 33; Nitecki, kol. 88.
} 
secratus [est], accepta prius vigore brevis apostolici per suum mandatarium bonorum dicti episcopatus canonica possessione.

Fiałkowski Antoni arcybiskup (Kamieniec - Mohylów) sakra 24 X [12 X st.st.] 1858 (niedziela) • Sankt Petersburg ${ }^{35}$

ASV, Archivio Concistoriale, Processus Consistorialis, vol. 257, s. 27 (Testimonium consecrationis per Illustrissimum ac Excellentissimum Dominum Venceslaum Żyliński, ab eo datum die 18. mensis Octobris v.s. [1858]).

[Nos] Venceslaus Żyliński, [...] archiepiscopus Mohyloviensis, metropolitanus omnium Romano-Catholicarum in Imperio Rossico Ecclesiarum [...], universis et singulis $[\ldots]$ fidem indubiam facimus et significamus: qualiter nos visa et diligenter lecta copia bullarum Sanctissimi Domini nostri Pii Papae IX [...], in qua apostolica auctoritate cuilibet episcopo in communione Ecclesiae Catholicae existenti conceditur facultas nomine Sanctissimi Papae munus consecrationis episcopalis Illustrissimo ac Reverendissimo Domino electo Thanasiensi, suffraganeo Camenecensi Antonio Fiałkowski conferendi, [...] eundem Illustrissimum ac Reverendissimum Dominum Antonium Fiałkowski, [...] infulatum Szydloviensem, praelatum cantorem cathedrae Vilnensis [...], adsistentibus Illustrissimis ac Reverendissimis Dominis Adamo Wojtkiewicz, episcopo Minscensi, et Vincentio Lipski, episcopo Jonopolitano, suffraganeo Tiraspolensi, [...] intra missarum solemnia $[\ldots]$ in episcopum Ecclesiae Thanasiensis, suffraganeum Camenecensem, anno Incarnationis Domini millesimo octingentesimo quinquagesimo octavo, mensis Octobris, die 12. veteris styli, quae fuit Dominica XXII post Pentecostes, in ecclesia parochiali S. Catharinae Viriginis [et] Martyris sub regimine Patrum Ordinis Praedicatorum in Petropoli, rite consecravimus.

\section{2}

Fredro Mikołaj Gabriel biskup (Baków)

sakra 10 VIII 1627 (wtorek) • Rzym

ASV, Miscellanea, Armadia XIII 33, k. 180r [178r]

Dominica, die $8^{\mathrm{a}}$ mensis Augusti 1627, [...] Dominus Frater Gabriel de Plezowice Fredro, Ordinis Minorum Observantium Sancti Francisci, electus Baccoviensis, praestitit fidelitatis debitae solitum iuramentum in manibus Illustrissimi et Reve-

${ }^{35}$ Por. Wasilewski, Arcybiskupi i administratorowie, s. 90. Zob. także Polonica, s. 170, nr 44-45; Dola (I), s. 268, nr 49; Nitecki, kol. 97-98.

${ }^{36}$ Por. Dola (I), s. 257, nr 5 (data sakry 26 VIII 1627). Zob. także Szostkiewicz, s. 448; Nitecki, kol. 103. 
rendissimi Domini Cardinalis Aldo ${ }^{\mathrm{a}-}\left[\right.$ brandini $^{\text {-a }}$, praesentibus ibidem Illustrissimo Domino Fratre Silvestro Scotto, equite Hierosolymitano, et Admodum Reverendo

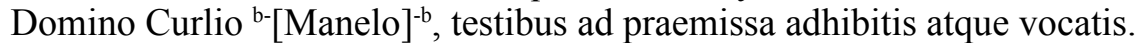

Feria $3^{a}$, die decima Augusti, in festivitate S. Laurentii Martyris anno 1627, [...] Illustrissimus et Reverendissimus in Christo Pater et Dominus, Dominus Cosmus, tituli S. Pancratii S.R.E. presbyter cardinalis, Torres nuncupatus, vivae vocis oraculo, Romae, in ecclesia S. Mariae in Araecoeli, consecravit in episcopum et pastorem Ecclesiae Baccoviensis Reverendissimum Dominum Fratrem Gabrielem de Plezowice Fredro, Ordinis Minorum Observantium S. Francisci, assistentibus sibi Reverendissimis in Christo Patribus Dominis Consalvo Durante, episcopo Feretrano, et Germanico Mantica, episcopo Famagustano, praesentibus ibidem Admodum Reverendo Domino Alessandro Buccio, presbytero Spoletanensis dioecesis, et Domino Joanne Baptista Saccho[?], Mediolanensis, testibus etc.

Gembart Józef biskup (Gniezno) $\quad$ sakra 20 XI 1814 (niedziela) • Warszawa ${ }^{37}$

AAGn, ACons D 8, s. 548-549 (Testimonium consecrationis episcopi Patarensis, Illustrissimi Gembarth).

[Nos] Ignatius comes Nałęcz de Małoszyn et Raczyno Raczyński, princeps archiepiscopus Gnesnensis etc., [...] notum facimus et attestamur, quia nos [...] munus consecrationis Illustrissimi, Reverendissimi Josephi Gembarth, electi episcopi Patarensis, suffraganei, vicarii in spiritualibus et officialis nostri generalis Gnesnensis, recepto prius ab eodem [...] fidelitatis iuramento, in ecclesia parochiali Sanctae Crucis Varsaviae Congregationis Missionis, dioecesis Varsaviensis, sub iurisdictione nostra administratorialia existente, Dominica vigesima quinta, quae fuit vigesima quarta et ultima post Pentecosten, quinta vero Novembris, quaeque fuit dies vigesima mensis Novembris anni currentis millesimi octingentesimi quarti decimi, [...] explevimus, Excellentissimis, Illustrissimis, Reverendissimis Adalberto Skarszewski, episcopo Lublinensi, Ordinum Aquilae Albae et Sancti Stanislai equite, Clemente Joanne Gołaszewski, episcopo Wigrensi, huiusmodi consecrationi assistentibus.

Gembicki Andrzej biskup (Gniezno - Łuck) sakra [27 lub 24] VIII 1628 (niedziela [lub czwartek]) • Lowicz ${ }^{38}$

${ }^{\mathrm{a}-\mathrm{a}}$ karta uszkodzona ${ }^{\mathrm{b}-\mathrm{b}}$ urwany brzeg karty.

${ }^{37}$ Por. „Kurier Litewski”, nr 95 z 28 XI 1814, s. [5]; Korytkowski, t. 2, s. 52. Zob. również Nitecki, kol. 111-112.

${ }^{38}$ Por. Korytkowski, t. 2, s. 58. Zob. także Szostkiewicz, s. 452; Nitecki, kol. 112. 
ASV, Archivio Concistoriale, Processus Consistorialis, vol. 36, k. 178v-179r

[Nos] Joannes Vęzik, Dei et Apostolicae Sedis gratia archiepiscopus Gnesnensis, legatus natus, Regni Poloniae primas primusque princeps, significamus praesentibus literis nostris, quorum interest, quia nos Reverendissimum Dominum Andream Gembicki, abbatem Tremesnensem, vigore literarum apostolicarum in forma bullae nobis exhibitarum, in ecclesia nostra collegiata Łoviciensi Beatissimae Mariae Virginis, missam celebrante iuxta praescriptum Pontificalis Romani, in episcopum Theodosiensem consecravimus eundemque in suffraganeum archidioecesis nostrae eligimus et deputavimus. Quocirca et hoc idem munus suffraganei tam in ecclesia nostra metropolitana, quam in archidioecesi nostra Gnesnensi libere et licite exerceat proventusque ad suffraganeum pertinens percipiat volumus et hoc ad notitiam tum aliorum omnium quorum interest tum praesertim admodum reverendorum dominorum praelatorum et canonicorum ecclesiae nostrae metropolitanae Gnesnensis deducimus. [...] Datum in arce nostra Loviciensi, die XXVIII mensis Augusti anno Domini MDCXXVIII.

\section{5}

Gembicki Wawrzyniec arcybiskup (Chełmża - Włocławek - Gniezno) sakra 1 IV 1601 (niedziela) $\bullet[\text { Warszawa }]^{39}$

ADPelp, C 1, k. 75v (list biskupa Wawrzyńca Gembickiego do kanonika chetmińskiego Odineta Perrenot z daty: Warszawa, 3 IV 1601 r.)

Die Dominico praeterito, Divina adiuvante benignitate, Illustrissimus et Reverendissimus [Claudius Rangoni], nuncius apostolicus, me [autorem listu biskup W. Gembicki] in ordinem episcopalem solemni et usitata Ecclesiae Catholicae caeremonia consecravit. Precor Deum Immortalem, ut ea res Ecclesiae nostrae Culmensis feliciter eveniat.

\section{6}

Geritz Józef Ambroży biskup (Warmia - Warmia) sakra 23 VIII 1840 (niedziela) • Frombork ${ }^{40}$

$A A W O, A B H 149$, s. 2.

${ }^{39}$ Ostatnio J. K. Kalinowski, Wawrzyniec Gembicki jako biskup diecezji chetmińskiej i pomezańskiej diecezji wieczysty administrator (1600-1610), Toruń 2011, s. 77 nn. Zob. także Szostkiewicz, s. 453; Dola (I), s. 260, nr 28; Nitecki, kol. 113-114.

${ }^{40}$ Por. Polonica, s. 171, nr 51. Zob. również Dola (I), s. 296, nr 42; Nitecki, kol. 114. 
Anno 1840, Dominica XI post Pentecosten, die 23. Augusti, in ecclesia cathedrali Varmiensi, [ego Andreas Stanislaus ab Hatten, episcopus Varmiensis], Illustrissimum Josephum Geritz, decanum et canonicum Varmiensem, in episcopum Abderitanum consecravi, assistentibus Perillustribus, Reverendissimis Joanne Lamprecht et Theodoro Hoppe, canonicis ecclesiae cathedralis Varmiensis.

AAWO, AB H 150, s. 5.

Ego Josephus Ambrosius [Geritz] anno Domini 1840, Dominica XI post Pentecosten, quae fuit dies $23^{\text {tia }}$ mensis Augusti, vigore apostolicarum literarum Sanctissimi Domini nostri Gregorii Papae XVI de quinto Kalendas Maii anni eiusdem (27 ${ }^{\mathrm{ma}}$ Aprilis), ab Illustrissimo ac Reverendissimo Domino Andrea Stanislao ab Hatten, protunc episcopo Varmiensi, in ecclesia cathedrali Varmiensi, ad aram maiorem, in choro existentem, inter missae conventualis solemnia, assistentibus, vigore specialis dispensationis Sanctae Apostolicae Sedis, Perillustribus, Reverendissimis Dominis, Dominis Joanne Lamprecht et Theodoro Hoppe, ecclesiae Varmiensis canonicis, in episcopum fui consecratus. Porro dies meae consecrationis fuit sacra S. Hyacintho Confessori sub ritu I ${ }^{\text {mae }}$ classis et octava festi Assumptionis Beatissimae Dei Genetricis.

Giedroyć Jan Stefan biskup (Wilno [Białoruś] - Inflanty/Wenden - Żmudź/Miedniki) sakra 12 II 1764 (niedziela) $\bullet$ Wilno $^{41}$

CVIA, F 1135 ap 20, k. 213v (Consecratio Illustrissimi Giedroyć).

[Die] 12 $2^{\mathrm{a}}$ Februarii [1764], Dominica VI post Epiphaniam. Post 10 ${ }^{\mathrm{mam}} \mathrm{P}$. Langans, C. Braseyko et plures scholastici consesserunt [concesserunt?] ad cathedralem ecclesiam [Vilnensem] pro videndis ceremoniis in consecratione Illustrissimi, Excellentissimi, Reverendissimi Domini Stephani Giedroyć, suffraganei Albae Russiae, in episcopum Uranopolitanum. Post prandium in palatio Illustrissimi loci ordinarii celebratum cum explosione tormentorum bellicorum ac militaris assistentiae domesticae, cui aderat invitatus reverendus pater rector academicus ab Illustrissimo cum aliis domiciliorum. Praesidentibus Pater Bulhak, professor rhetorices, praevia oratione exhibuit panegyrium parvam, dictam wolant, cum versibus orno et vernaculo sermone, gratulatoriam novae dignitatis pastoralis, dein eundem honorem gratulati sunt domini academici scholares.

${ }^{41}$ Zob. M. Wołonczewski, Biskupstwo żmujdzkie, Kraków 1989, s. 107; Szostkiewicz, s. 455; Nitecki, kol. 115-116; Wiadomości, s. 300 (tamże przyp. 30). Nadto T. Kasabuła, Ignacy Massalski, biskup wileński, Lublin 1998, s. 154-155. 


\section{8}

Glazer Jakub biskup (Przemyśl)

sakra $23 X 1887$ (niedziela) • Przemyśl $l^{42}$

AAPrzem, 151, s. 55

Die 23. Octobris [1887] Illustrissimus ac Reverendissimus Dominus, Dominus Lucas de Ostoja Solecki, episcopus Premisliensis, consecravit Illustrissimum et Reverendissimum Dominum, Dominum Jacobum Glazer ad onus episcopi suffraganei, assistentibus Illustrissimis ac Reverendissimis Dominis, Dominis Joannis Saturno Stupnicki, episcopi ritus Graeci [Premisliensis], et Joanni de Kozielsko kniaź Puzyna, episcopi suffraganei Leopoliensis ritus Latini, in ecclesia [cathedrali Premisliensi]; praesentes erant Illustrissimi et Reverendissimi Domini, Domini Severinus de Dąbrowa Morawski, archiepiscopus [Leopoliensis] ritus Latini, et Isaias Nicolaus de Isakowicz, archiepiscopus [Leopoliensis] ritus Armeni; cum titulo: episcopus in partibus infidelium Gabalitanus.

Goldtmann Józef Joachim biskup (Włocławek - Sandomierz) sakra 18 XI 1838 (niedziela) $\bullet$ Warszawa ${ }^{43}$

ADWt, AKap 41(433), k. $26 r$.

Illustrissimus ac Reverendissimus Josephus Goldtmann, archidiaconus cathedralis [Vladislaviensis], die 18. mensis Novembris anni currentis [1838] consecratus [est] Varsaviae in suffraganeum dioecesis Vladislaviensis seu Calissiensis.

40

Golaszewski Antoni biskup (Przemyśl)

sakra $15 \times 1786($ niedziela $) \cdot$ Lwów $^{44}$

Ossolineum, 1735/II, k. $7 r$.

Anno Domini 1786, die 15. Octobris, quae fuit Dominica decima nona post Pentecosten, Illustrissimus, Excellentissimus ac Reverendissimus Dominus Ferdinandus Kicki, archiepiscopus metropolitanus Leopoliensis, infra missarum solemnia, in ecclesia sua cathedrali consecravit in episcopum Premisliensem Illustrissimum ac Reverendissimum Dominum Antonium de Gołaszewski. Circa hanc consecra-

${ }^{42}$ Zob. Nitecki, kol. 118.

${ }^{43}$ Por. Chodyński, s. 80. Zob. również Nitecki, kol. 122.

${ }^{44}$ Por. Relacje arcybiskupów lwowskich 1595-1794, wyd. T. Długosz, Lwów 1937, s. 127-128 („die 15. Octobris [1786], Dominica 19. post Pentecosten”); Wiadomości, s. 300 (tamże przyp. 32); Polonica, s. 172, nr 56; Sarna, t. 2, s. 513. Zob. również Dola (I), s. 291, nr 55; Nitecki, kol. 123. 
tionem, iuxta bullas apostolicas et praescripta Sedis Apostolicae mandata in conconsecratores assumpti, requisiti et rogati sumus ego [odnosi sie do arcybiskupa lwowskiego obrzadku ormiańskiego Jakuba Waleriana Tumanowicza] una [cum] Illustrissimo et Reverendissimo R[omano] Sierakowski, suffraganeo Premisliensi; et una simul cum Illustrissimo, Excellentissimo archiepiscopo metropolitano consecratore, quae conconsecratores simul cum ipso iuxta praescriptum Pontificalis Romani adimplevimus et executi sumus omnia.

\section{1}

Gołaszewski Jan Klemens biskup (Wigry/Sejny) sakra 5 III 1809 (niedziela) $\cdot$ Warszawa ${ }^{45}$

AAGn, ACons D 7, s. 212 (Testimonium consecrationis episcopi Wigrensis, Illustrissimi Golaszewski)

[Nos] Ignatius comes Nałęcz de Małoszyn et Raczyno Raczyński, princeps archiepiscopus Gnesnensis etc., universis et singulis [...] notum facimus et attestamur, quia nos [...] munus consecrationis Illustrissimi, Excellentissimi, Reverendissimi Joannis Clementis Gołaszewski, electi episcopi Vigrensis, recepto prius ab eodem [...] fidelitatis iuramento, in ecclesia cathedrali S. Joannis Varsaviae, Dominica tertia Quadragesimae, quae fuit dies quinta mensis Martii anno currenti $1809,[\ldots]$ explevimus, assistentibus huiusmodi consecrationi Illustrissimis, Excellentissimis, Reverendissimis Dominis Timotheo Gorzeński, Smolenscensi et administratore dioecesis Posnaniensis, Antonino Malinowski, Cynnensi, episcopis.

Gorczyński Antoni biskup ([Kijów])

sakra 29 IV $1770\left(\right.$ niedziela) $・$ Dunajów $w^{46}$

AGAD, Dziat III, zespót 396; 247, k. 71r.

Anno Domini 1770, die 29. Aprilis, quae fuit Dominica $2 \frac{\mathrm{da}}{\text { a }}$ post Pascha, in ecclesia parochiali Dunajoviensi, [archiepiscopus Leopoliensis Venceslaus Hieronymus Sierakowski] consecravit solenni ritu Illustrrissimum et Reverendissimum Antonium Gorczynski, decanum cathedralem et officialem generalem Kiioviensem ad episcopatum Coronensem, assistentibus sibi Illustrissimis et Reverendissi-

${ }^{45}$ Por. W. Jemielity, Diecezja augustowska czyli sejneńska w latach 1818-1872, Lublin 1972, s. 31. Zob. również Dola (I), s. 256, nr 2; Nitecki, kol. 123; Polonica, s. 172, nr 57.

${ }^{46}$ Zob. Szostkiewicz, s. 458; Nitecki, kol. 125-126; Polonica, s. 172, nr 58. 
mis Jacobo Augustynowicz, ritus Armeni archiepiscopo Leopoliensi, et Raymundo Jezierski, episcopo Baccoviensi.

43

Goślicki Wawrzyniec biskup (Kamieniec - Chełm/Krasnystaw - Przemyśl - Poznań) sakra 12 VII 1587 (niedziela) $\cdot$ Warszawa ${ }^{47}$

ASV, Archivio Concistoriale, Processus Consistorialis, vol. 10, k. $288 r$

Forma iuramenti apostolici per Reverendissimum Dominum Laurentium Gosliczki, episcopum Camenecensem, die 12. Julii anno Domini 1587 in consecratione sua Varsaviae in $\mathrm{s}[\mathrm{u}] \mathrm{mmo}$ templo in manibus Reverendissimi Domini archiepiscopi Leopoliensis facti.

\section{4}

Górski Wojciech Józef biskup (Kielce) $\quad$ sakra 15 X 1809 (niedziela) $・$ Kraków ${ }^{48}$ AKMK, LOrd 14, s. 45

Illustrissimus, Reverendissimus Dominus episcopus Cracoviensis, Dominica XXI post Pentecosten, videlicet die $15^{\text {ta }}$ mensis Octobris 1809 anno, in ecclesia sua cathedrali Cracoviensi, ad maius altare, [...] consecravit Illustrissimum ac Reverendissimum Adalbertum de Boża Wola Gorski, electum in episcopum Ecclesiae Kielcensis, assistentibus Reverendissimi Drzewiecki, abbate Ordinis Cisterciensium monasterii Andreoviensis, et Illustrissimo Łańcucki, archipresbitero ecclesiae archipresbyteralis parochialis Beatissimae Virginis Mariae Cracoviae.

ASV, Archivio Nunziatura di Vienna, vol. 239, $k$. 117 r (list biskupa kieleckiego W. J. Górskiego do nuncjusza apostolskiego w Wiedniu, arcybiskupa Antonio Gabriele Severoliego, z daty: Kielce, 23 I 1810). Zob. również ASPF, Scritture riferite nei Congressi. Moscovia - Polonia - Ruteni, vol. 19, k. 4 r (pismo biskupa W.J. Górskiego do papieża Piusa VII z daty: Kielce, 14 III 1812: „,Adalbertus Gorski, episcopus Kielcensis, post suam praeconisationem in anno 1803, postquam ad gradum episcopi consecratus 15. Octobris 1809 anno et ad suam cathedram installatus extiterit, episcopalis sui officii sequentes explevit functiones" etc.)

${ }^{47}$ Por. Sarna, t. 1, s. 205-206; Pawelec, cz. 6, s. 392, nr 25. Zob. także Szostkiewicz, s. 459-460; Nowacki, t. 2, s. 103-104; Dola (I), s. 258, nr 21; Nitecki, kol. 127.

${ }^{48}$ Por. L. Łętowski, Wspomnienia pamiętnikarskie, wyd. H. Barycz, Wrocław 1956², s. 123. Zob. Dola (I), s. 241, nr 1; Nitecki, kol. 130. 
Consecrationem in episcopum, quam mihi [odnosi się do biskupa W.J. Górskiego] diu Aula Caesareo-Regia denegabat, ex favore moderni regiminis adhuc 15. Octobris currentis anni ab Excellentissimo Domino episcopo Cracoviensi recepi.

\section{5}

Grossmann Franciszek biskup (Warmia)

sakra 29 IX 1844 (niedziela) • Frombork Fr $^{49}$

AAWO, AB H 150, s. 23

Anno Domini 1844, Dominica XVIII post P. [skreślone], quae fuit 29 $9^{\text {na }}$ Aprilis $[\text { sic! }]^{50}$, ad altare maturum in ecclesia cathedrali Varmiensi, [ego Josephus Ambrosius Geritz] consecravi in episcopum Illustrissimum ac Reverendissimum Franciscum Grossmann, episcopum Amyzonensem in partibus infidelium, suffraganeum et canonicum Varmiensem, assistentibus Perillustribus, Reverendissimis Dominis Josepho Theodoro Hoppe, decano, et Antonio Frenzel, designato praeposito, ecclesiae Varmiensis, praevia super hoc Sanctae Apostolicae Sedis dispensatione.

\section{6}

Gzowski Franciszek biskup (Wilno [Troki]) sakra 29 XII $1782\left(\right.$ niedziela) $\bullet$ Wilno $^{51}$

APBKr, S-Wi-4, s. 312.

Hac die, scilicet 29. Decembris [1782], in qua incipit Dominica infra Nativitatem Domini Nostri Jesu Christi, Celsissimus loci ordinarius [Vilnensis], in assistentia numerosorum illustrissimorum dominorum praelatorum, canonicorum aliarumque spiritualium personarum, in praesentia quoque numerose congregatorum dominationum, cum magna solemnitate in ecclesia S. Joannis parochiali consecravit Illustrissimos, Reverendissimos Dominos Petrum Samsonem Toczyłowski, cantorem ac officialem generalem Vilnensem, in episcopum Bellinensem ac suffraganeum Vilnensem, ac Illustrissimum, Reverendissimum Dominum Franciscum Gzowski, canonicum nec non surrogatum Vilnensem, in episcopum Tespiensem et suffraganeum Trocensem. Con-consecratores fuere Illustrissimi, Reverendissimi Domini Zienkowicz, episcopus Ariopolitanus, et Wołczacki, episcopus Tomassensis.

${ }^{49}$ Por. Polonica, s. 173, nr 64. Również Nitecki, kol. 133.

${ }^{50}$ Widniejący w zapisce miesiąc kwiecień (Aprilis) jest ponad wszelką wątpliwość mylny, bowiem prekonizację papieską F. Grossmann uzyskał dopiero 17 VI 1844 r. (zob. literaturę w poprzednim przypisie).

${ }^{51}$ Por. Wiadomości, s. 301; T. Kasabuła, Ignacy Massalski, biskup wileński, s. 169. Zob. także Szostkiewicz, s. 451 (mylna forma nazwiska Gazowski); Nitecki, kol. 138. 
de Hatten (Hattyński) Andrzej Stanisław biskup (Warmia - Warmia) sakra 11 X 1801 (niedziela) • Oliwa [Gdańsk $]^{52}$

AAWO, AB H 149, s. $1\left[\right.$ k. $1^{C}$ r]

Ego Andreas Stanislaus ab Hatten [...] anno Domini millesimo octingentesimo primo, Dominica vigesima post Pentecosten, quae fuit dies undecima mensis Octobris, ad mandatum Sanctissimi Domini nostri Pii Divina providentia Papae Septimi, de die undecima Augusti anni millesimi octingentesimi, Olivae, in ecclesia monasterii Cistertiensis, a Celsissimo, Illustrissimo ac Reverendissimo Domino Carolo e Sacri Romani Imperii principibus de Hohenzollern, principe episcopo Varmiensi, abbate commendatario Olivensi, [...] assistentibus vigore dispensationis apostolicae de die decima tertia mensis Augusti anni millesimi octingentesimi Perillustribus, Reverendissimis Josepho e Sacri Romani Imperii principibus comite de Hohenzollern, et Aloysio de Melitz, canonicis ecclesiae cathedralis Varmiensis, in episcopum Dianensem consecratus [sum].

Hohenzollern-Hechingen Jan Karol biskup (Chełmża - Warmia) sakra 4 X 1778 (niedziela) • Oliwa [Gdańsk $]^{53}$

ADPelp, AKKCh, A 14, k. 63r (sesja nadzwyczajna kapituty 18 IX 1778)

In hoc capitulo propositum est negotium, quod immineat actus consecrationis Illustrissimi Joannis comitis de Hohenzollern, futuri coadiutoris episcopatus Culmensis, quae consecratio expedita est in ecclesia Olivensi conventus Cisterciensis die 27. Septembris [1778], proinde ad assistendum tali actui deputari debent delegare a venerabile capitulo, qui pro honore et nomine capituli ibidem parere tenentur. Ad hunc actum explenendum obtulerunt alachritatem suam Perillustres Reverendissimi Domini Gralewski et Wolski, quibus in forma solita instructio extradenda decernitur.

ADPelp, AKKCh, A 14, k. 63v-64r (sesja nadzwyczajna kapituly 15 X 1778). Zob. również tamże, AKKCh, A 70, k. 67v (,, in episcopum Dibonensem consecratus Olivae per principem episcopum Varmiensem, comitem Krasicki, assistentibus Andreae Baier, episcopo Culmensi, et de Zemen, episcopo suffraganeo Varmiensi, anno 1778 ").

\footnotetext{
${ }^{52}$ Zob. Nitecki, kol. 140-141; Polonica, s. 174, nr 67.

${ }^{53}$ Por. Polonica, s. 174, nr 69. Zob. również Dola (I), s. 261, nr 50; Nitecki, kol. 150.
} 
Perilustres Reverendissimi Domini Gralewski et Wolski fecerunt relationem, quod munus suum executi sunt assistentiam praebentes consecrationi Illustrissimi Joannis comitis de Hohenzollern, coadiutoris episcopatus Culmensis, quae expedita est non die 27. Septembris, ut connotatum in capitulo extraordinario die 18. Septembris celebrato, sed Dominica $18^{\text {va }}$ post Pentecosten, in ecclesia Olivensi Ordinis Cisterciensis, quam consecrationem consecrant Illustrissimi, Excellentissimi Domini Ignatius Krasicki, episcopus Varmiensis et Sambiensis, Andreas Ignatius Baier, episcopus Culmensis et Mariaeburgensis [k. 64r] in Pomesania, Carolus Cemma [sic!], suffraganeus Varmiensis, circa assistentiam cleri competentem, quam attendentiam a venerabile capitulo per perillustres reverendissimos delegatos praestitam grato animo acceptavit Illustrissimus loci ordinarius.

\section{9}

Hohenzollern-Hechingen Józef biskup (Warmia)

sakra 12 VII 1818 (niedziela) • Frombork $^{54}$

AAWO, AB H 149, s. 1 [k. $\left.1^{C} r\right]$

Ego Andreas Stanislaus ab Hatten, [episcopus Dianensis], anno Domini 1818, Dominica IX post Pentecosten, quae fuit dies 12. Julii, Frauenburgi, in ecclesia cathedrali Varmiensi, Celsissimum principem Josephum ab Hohenzollern in episcopum Varmiensem consecravi, assistentibus praevia dispensatione apostolica Perillustribus, Reverendissimis Ignatio de Mathy, praeposito, et Justo de Soczewski, canonico, Varmiensibus.

50

Horain Aleksander biskup (Żmudź)

sakra 16 III $1732\left(\right.$ niedziela) $\bullet$ Warszawa ${ }^{55}$

BN, BOZ 941, s. 81

Die 16. Martii [1732], in templo Sanctae Crucis [Varsaviae], Illustrissimus nuncius [apostolicus] consecravit Illustrissimum Horain, electum Hirenensem. Assistentes episcopi fuere Illustrissimis Hosius, Camenecensis episcopus, et Rostkowski, suffraganeus Luceoriensis.

${ }^{54}$ Por. Polonica, s. 174, nr 70. Zob. również Dola (I), s. 296, nr 40; Nitecki, kol. 150-151.

${ }_{55}$ Por. Wiadomości, s. 301-302 (tamże przyp. 37). Zob. także Wołonczewski, Biskupstwo żmujdzkie, s. 96; Szostkiewicz, s. 467-468; Nitecki, kol. 153. 
Hozjusz Stanisław Józef biskup (Przemyśl - Inflanty/Wenden - Kamieniec - Poznań) sakra 23 IV 1719 (niedziela) $・$ Kraków $^{56}$

AKMK, LOrd 6, s. 545. Zob. również AKMK, LOrd 8, k. 1r (księga czynności pontyfikalnych S.J. Hozjusza, rozpoczynajaca się od daty 23 V 1719: „, Acta pontificalium functionum [...] peractarum ab anno millesimo septingentesimo decimo nono, die vigesima tertia mensis Maii”).

Illustrissimus et Reverendissimus Dominus Michaël in Słupow Szembek, episcopus Paphensis, suffraganeus et decanus Cracoviensis, consecravit magno populo concursu in circulo ecclesiae archipresbyteralis Cracoviensis Beatae Mariae Virginis Illustrissimum et Reverendissimum Dominum Joannem de Czekarzowice Tarło, episcopum Kijoviensem, et Reverendissimum Stanislaum de Bezdan Hosium, suffraganeum Przemysliensem cum honore episcopatus Uticensis, in assistentia Illustrissimi et Reverendissimi Domini Petri Tarło, suffraganei Posnaniensi, nominati Livoniensi, et Illustrissimi et Reverendissimi [pozostawiono miejsce na wpisanie imienia] Szaniawski, suffraganei Leopoliensi, anno ut supra 1719, die vero 23. Aprilis.

Janowski Florian Amand biskup (Tarnów)

sakra 13 VIII $1786 \cdot$ Lwów $^{57}$

Ossolineum, 1735/II, k. $6 v$.

Anno Domini 1786, die 12. [sic!] Augusti, iam vero ea dies fuit Dominica decima post Pentecosten, Illustrissimus, Excellentissimus ac Reverendissimus Dominus Ferdinandus Kicki, archiepiscopus et metropolitanus Leopoliensis, in ecclesia sua cathedrali consecravit in episcopum Tarnoviensem Illustrissimum Florianum Janowski, abbatem Tinicensem, quem Augustissimus imperator Josephus Secundus nominavit et praesentavit Beatissimo Pio VI eius nominis, feliciter regnantes, novumque hoc anno eundem episcopatum fundavit. Hic vero episcopus qua consecrator rogatus et requisitus sum [odnosi sie do arcybiskupa lwowskiego obrzadku ormiańskiego Jakuba Waleriana Tumanowicza] una cum Illustrissimo Petro Bielanski, episcopo ritus Graeci uniti, conconsecravimus iuxta praescriptum sacrorum canonum et Pontificalis.

${ }^{56}$ Por. Przybyszewski, s. 62. Zob. także Szostkiewicz, s. 469; Nowacki, t. 2, s. 111-112; Nitecki, kol. 154-155; Szczepaniak, Duchowieństwo diecezji krakowskiej w XVIII wieku, s. 595-596.

${ }^{57}$ Por. Relacje arcybiskupów lwowskich 1595-1794, s. 127 (,in anno 1786, die 13. Augusti, Dominica $10^{\mathrm{ma}}$ post Pentecosten”); Wiadomości, s. 302-303; Polonica, s. 176, nr 80. Zob. również Dola (I), s. 293, nr 1; Kumor, Diecezja tarnowska, s. 251-252; Nitecki, kol. 175; Szczepaniak, Duchowieństwo diecezji krakowskiej w XVIII wieku, s. 599. 
53

Jezierski Rajmund Stanisław biskup (Baków) sakra 4 V 1738 (niedziela) $・$ Kielce $^{58}$

AKapMK, LA 36, s. 27. Zob. również ADPelp, AKKCh, A 16, s. 110 (nr 1)

Anno Domini 1738, die 4. Maii, Kielciis, in ecclesia collegiata Kielcensi, Eminentissimus et Reverendissimus Dominus cardinalis Lipski, episcopus Cracoviensis, dux Severiae, consecravit uno die duos, scilicet Illustrissimum et Reverendissimum Dominum Sierakowski, episcopum [pozostawiono miejsce na wpisanie nazwy stolicy tytularnej], coadiutorem Livoniae, et Illustrissimum et Reverendissimum Dominum Jezierski, episcopum Valachiae seu Bacoviensem.

\section{4}

Karp Jozafat Michał biskup (Żmudź) sakra 27 I 1737 (niedziela) • Wilno ${ }^{59}$

BN, BOZ 941, s. 88

[Die] 27. Januarii [1737] Karp, nominatus Samogitiae, qui hebdomada una ante venerat, consecratus est in cathedra [Vilnensi] ab episcopo Vilnensi et suffraganeis Vilnensi et Samogitiensi.

\section{5}

Karwosiecki Dominik Piotr biskup (Baków)

sakra 1 I 1775 (niedziela) $・$ Dunajów Do $^{60}$

AGAD, Dziat III, zespót 396: 247, k. 79r

Anno Domini $1775^{\text {to }}, 1^{\text {ma }}$ Januarii, in festo Circumcisionis Domini Nostri Jesu Christi, quae dies fuit Dominica, in ecclesia praepositurali Dunajovieni, [archiepiscopus Leopoliensis Venceslaus Hieronymus Sierakowski] solenni ritu consecravit Illustrissimum et Reverendissimum Dominicum Karwosiecki, ex Ordine S. Francisci Conventualium, in episcopatum Bybliensem, coadiutorem episcopa-

${ }^{58}$ Por. B. Kędzierski, Wiadomość o krzewieniu wiary świętej w Mołdawii y Wołoszczyznie, ustanowieniu katedry i następowaniu biskupów ceretyńskich, po tym bakowskich [...], Lwów 1774, s. 14. Zob. także Szostkiewicz, s. 481-482; Dola (I), s. 257, nr17; Nitecki, kol. 183; Wiadomości, s. 303; Szczepaniak, Duchowieństwo diecezji krakowskiej w XVIII wieku, s. 602.

${ }^{59}$ Por. Wiadomości, s. 303 (tamże przyp. 45); Wołonczewski, Biskupstwo żmujdzkie, s. 95. Zob. także Szostkiewicz, s. 483; Dola (I), s. 281, nr 31; Nitecki, kol. 196.

${ }^{60}$ Por. Kędzierski, Wiadomość o krzewieniu wiary świętej w Mołdawii y Wołoszczyznie, s. 25, 40-41; Dola (I), s. 257, nr 19 (data sakry 1 VI 1775). Zob. także Szostkiewicz, s. 484; Nitecki, kol. 197. 
tus Baccoviensis, assistentibus Illustrissimis et Reverendissimis Jacobo Tumanowicz, episcopo Camacensi, coadiutore archiepiscopo ritus Armenorum, et Crispino Cieszkowski, episcopo Nissensi.

\section{6}

Kaznowski Franciszek biskup (Poznań)

sakra 20 XI 1729 (niedziela) $\bullet$ Poznañ ${ }^{61}$

AAPzn, ASO 7, k. 57r

Anno Domini 1729, die vigesima Novembris, quae erat Dominica 24. et ultima post Pentecosten, Posnaniae, in ecclesia cathedrali Posnaniensi, Illustrissimus, Excellentissimus et Reverendissimus Joannes Joachymus comes de Tęczyn et Czekarzewice Tarło, episcopus Posnaniensis, consecravit Illustrissimum et Reverendissimum Franciscum in Kaznow Kaznowski, suum suffraganeum, archidiaconum Pczevensem, officialem generalem, in episcopum Domiciopolitanum; tanquam conconsecrator adstitit Illustrissimus et Reverendissimus Dominus Franciscus Kraszkowski, episcopus Dardaniensis, suffraganeus, vicarius in spiritualibus et officialis generalis Gnesnensis, abbas commendatarius Vitoviensis, una cum Illustrissimo et Reverendissimo Domino Francisco Kobielski, episcopo Antinopolitano, suffraganeo Vladislaviensi.

\section{7}

Kicki Ferdynand Onufry arcybiskup (Lwów - Lwów)

sakra 15 II 1778 (niedziela) • Dunajów D2 $^{62}$

ASV, Archivio Concistoriale, Processus Consistorialis, vol. 175, k. 398v/400r

Ego infrascriptus notarius apostolicus mandatum Sanctae Sedis Apostolicae de consecrando Illustrissimo et Reverendissimo Domino Ferdinando Kicki, electo episcopo Targensi, suffraganeo Leopoliensi, publice legi atque eundem Illustrissimum et Reverendissimum electum Targensem praeinsertum fundamentum cum sponsione et voto in manibus Illustrissimi et Reverendissimi Domini Jacobi Augustinowicz, archiepiscopi Leopoliensis Armenorum, consecratoris, in capella palatii Celsissimi, Excellentissimi et Reverendissimi Domini, Domini Venceslai Hieronymi de Bogusławice comitis Sierakowski, archiepiscopi metropolitani Le-

${ }^{61}$ Por. Polonica, s. 177, nr 88; Nowacki, t. 2, s. 189, nr 30. Zob. także Szostkiewicz, s. 484; Nitecki, kol. 198; Wiadomości, s. 303.

${ }^{62}$ Por. Krętosz, Organizacja archidiecezji lwowskiej, s. 104, nr 3; Krętosz, Archidiecezja lwowska obrzadku łacińskiego, s. 60, 70, 72-73. Zob. także Nitecki, kol. 200; Przybyszewski, s. 70; Polonica, s. 177-178, nr 89-90; Szczepaniak, Duchowieńtwo diecezji krakowskiej w XVIII wieku, s. 609 . 
opoliensis, [...] Dunajoviae siti, in praesentia eiusdem Celsissimi, Excellentissimi et Reverendissimi Domini comitis Sierakowski, archiepiscopi metropolitani, adversa valetudine detenti, pontificaliter assistentibus Illustrissimis et Reverendissimis Dominis Jacobo Tumanowicz, episcopo Camacensi, archiepiscopatus Leopoliensis Armenorum coadiutore, et Crispino Cieszkowski, episcopo Nyssensi, in conspectu multarum personarum [...] emisisse audivi, et post emissum idem iuramentum dictum Illustrissimum et Reverendissimum electum Targensem a praelaudato Illustrissimo et Reverendissimo archiepiscopo Leopoliensi Armenorum, ad hunc actum rogati, [...] legitime intra solemnia missae, ipsa Dominica Septuagesimae, quae fuit dies decima quinta mensis Februarii, anno currenti millesimo septingentesimo septuagesimo octavo, consecratum fuisse vidi.

\section{8}

Kicki Kajetan Ignacy arcybiskup (Lwów - Lwów) sakra 30 I 1785 (niedziela) $・$ Lwów ${ }^{63}$

ASV, Archivio Concistoriale, Processus Consistorialis, vol. 201, k. 306r-v (Testimonium consecrationis z daty: Lwów, 31 I 1785 r.)

Ferdinandus Onuphrius de Kitki Kicki, Dei et Apostolicae Sedis gratia archiepiscopus metropolitanus Leopoliensis [...] [universis et singulis notum facimus, quod] ab Illustrissimo et Reverendissimo Caietano Ignatio Kicki, electo episcopo Solensi, suffraganeo Leopoliensi constituto et deputato, iuramentum [...] in manibus nostris publice in facie ecclesiae nostrae metropolitanae Leopoliensi [...], praesentibus et pontificaliter assistentibus Illustrissimis et Reverendissimis Jacobo Tumanowicz, archiepiscopo Leopoliensi Armenorum, et Crispino Cieszkowski, episcopo Nyssensi, gratiam et communionem Sanctae Sedis Apostolicae habentibus, Dominica Sexagesimae, die vero [k. 306v] trigesima mensis Januarii anno Domini millesimo septingentesimo octogesimo quinto, de verbo ad verbum emissum recepimus, eundemque Illustrissimum et Reverendissimum Caietanum Ignatium Kicki, electum episcopum Solensem, intra missae solennia [...], in conspectu multorum Regni procerum et magnatum plurimarumque aliarum distinctarum personarum et numerosi populi utriusque sexus varii status et conditionis, consecravimus.

Ossolineum, 1735/II, k. 6r

Anno Domini 1785, die 30. mensis Januarii, quae fuit Dominica Sexagesima, Illustrissimus, Excellentissimus ac Reverendissimus Dominus Ferdinandus Kicki,

${ }^{63}$ Por. Polonica, s. 178, nr 91; Relacje arcybiskupów lwowskich 1595-1794, s. 127 (,,in anno 1785, die 30. Januarii, Dominica Sexagesimae”). Zob. również Krętosz, Organizacja archidiecezji lwowskiej, s. 104, nr 13; Krętosz, Archidiecezja lwowska obrządku łacińskiego, s. 61, 71, 73; Nitecki, kol. 200. 
archiepiscopus et metropolitanus Leopoliensis, in ecclesia sua cathedrali consecravit in episcopum Solensem in partibus et suffraganeum Leopoliensem Illustrissimum ac Reverendissimum Dominum Caietanum Kicki, nepotem suum. Circa hanc consecrationem, infra missarum solemnia, iuxta praescriptum canonum et mandata apostolica, in conconsecratores assumpti et rogati sumus ego [odnosi sie do arcybiskupa Jakuba Waleriana Tumanowicza] cum Illustrissimo Domino Crispino Cieszkowski, episcopo Nisseno, custode metropolitano Leopoliensi; huic consecrationi pontificaliter assistentes iuxta praescriptum Pontificalis Romani omnia per Illustrissimum consecratorem et per nos supraspecificatos conconsecratores sunt adimpleta et peracta.

\section{9}

Kiełczewski Dominik Józef biskup (Chetm/Krasnystaw) sakra 14 IX 1760 (niedziela) • Zamośćct

AKMK, LOrd 12, k. $1^{B}$ r (zob. również tamże, s. 123: „, Index expeditorum pontificalium omnium per Illustrissimum et Reverendissimum Dominum Dominicum Josephum in Kiełczew Kiełczewski, episcopum Hermopolitanum, suffraganeum Chetmensem, canonicum cathedralem Cracoviensem, collegiatarum Łoviciensis, Kielcensis et parochialis in Oswiecim praepositum, a die suae consecrationis subsecutae decima quarta mensis Septembris anno Domini millesimo septingentesimo sexagesimo in Zamość, dioecesis Chetmensis, usque ad obitum eius subsecutum Cracoviae, anno Jubilaei magni millesimo septingentesimo septuagesimo sexto, die Mercurii vigesima octava Februarii. Quiescit in Domino Cracoviae in Capella Maciejowsciana ecclesiae cathedralis").

Dominicus Josephus in Kiełczew Kiełczewski, Sacrae Theologiae utriusque iuris doctor, ecclesiae collegiatae cathedralis Cracoviensis canonicus, collegiatarum Loviciensis, Kielcensis et Oswiecimensis praepositus, ab Illustrissimo et Reverendissimo Domino Valentino Wężyk, protunc episcopo Chełmensi, consecratore, tum assistentibus conconsecratoribus Illustrissimis et Reverendissimis Dominis Maximiliano Ryłło, episcopo Chełmensi et Bełzensi ritus Graeco Uniti, et Raimundo Jezierski, episcopo Bacoviensi, Ordinis Praedicatorum, ritu solenni in episcopum Hermopolitanum consecratus [est] in ecclesia collegiata Zamoscensi anno Domini 1760, Dominica 16. post Pentecosten, quae fuit dies 14. Septembris.

${ }^{64}$ Por. Pawelec, cz. 7, s. 23, nr 10. Zob. także Szostkiewicz, s. 484; Nitecki, kol. 201; Wiadomości, s. 303 (tamże przyp. 47); Przybyszewski, s. 71-72. 


\section{0}

Kierski Józef Tadeusz biskup (Poznań - Przemyśl)
sakra 19 III 1737 (wtorek) • Poznañ ${ }^{65}$

AAPzn, ASO 8, k. [57r]. Zob. również ADPelp, AKKCh, A 16, s. 110 (nr 3).

Posnaniae, die 19. Martii [1737], Illustrissimus loci ordinarius [Stanislaus Josephus Hosius] consecravit Illustrissimum Josephum Kierski ad episcopatum Bolinensem et suffraganeatum Posnaniensem, sub assistentia Illustrissimi Francisci Kobielski, episcopi Kamenecensis, et Illustrissimi Sołtyk, suffraganei Culmensis.

61

Kłagiewicz Andrzej Benedykt biskup (Wilno - Wilno) sakra 12 IX [31 VIII st.st.] $1830\left(\right.$ niedziela) $\bullet$ Luck $^{66}$

ASV, Archivio Concistoriale, Processus Consistorialis, vol. 242, k. $716 r-v$.

[Nos] Michaël Joannes Lubicz Piwnicki, Dei et Apostolicae Sedis gratia episcopus Ramathensis, coadiutor cum successione Luceoriensis et Zytomiriensis, [...] universis et singulis [...] significamus, exhibitam nobis esse bullam Sacrae Sedis Apostolicae de data [6 IV 1830] expeditam, provisionem episcopatus Chrysopolitanensis in partibus infidelium, favore Illustrissimi et Reverendissimi Domini Andreae Benedicti Klongiewicz, suffraganei Wilnensis [...], emanatam [...]. Post cuius quidem bullae et transumpti praesentationem invitati fuimus ab Illustrissimo, Excellentissimo et Reverendissimo Domino archiepiscopo Mohiloviensi, metropolitano Ecclesiarum Romano-Catholicarum [k. 716v] in Imperio Rossiae [...], Gasparo Casimiro Cieciszowski, quatenus ad executionem eiusdem bullae procederemus et Illustrissimum Dominum Andream Benedictum Klongiewicz in episcopum Chrysopolitanum consecraremus. Nos igitur [...] anno Domini 1830, Dominica $14^{\text {ta }}$ post Pentecostes, quae fuit $31^{\text {a }}$ dies Augusti veteris styli, in ecclesia cathedrali Luceoriensi, in praesentia dicti Excellentissimi metropolitani, assistentibus nobis Illustrissimis et Reverendissimis Dominis Joanne Cantio Podhorodenski, episcopo Polemonensi, suffraganeo Luceoriensi [...], et Cirillo Sierocinski, episcopo Pinscensi ritus Graeci Latino-Uniti, [...] servatis omnibus solemnitatibus, in Rituali Romano exaratis, munus consecrationis ipsi contulimus [...]. Datum Luceoriae, die prima mensis Septembris millesimo octingentesimo trigesimo anno.

${ }^{65}$ Por. „Diario Ordinario”, 3060 (1737) z 15 III 1737, s. 12; Wiadomości, s. 303-304 (tamże przyp. 48); Sarna, t. 2, s. 479; Nowacki, t. 2, s. 189-190, nr 32. Zob. także Szostkiewicz, s. 484; Nitecki, kol. 201.

${ }^{66}$ Por. Polonica, s. 178, nr 92 (także, nr 93). Zob. również Nitecki, kol. 205-206. 


\section{2}

Komorowski Adam Ignacy arcybiskup (Gniezno)

$$
\text { sakra } 28 X 1749 \text { (wtorek) } \bullet \text { Kraków }{ }^{67}
$$

AKapMK, AAct 22, k. 40r-v (Actus consecrationis Celsissimi primatis). Tamże, $k .43 r$ -v: ,,Jovis, die 30. Octobris [1749]. Post absolutam nuper consecrationem Celsissimi principis nominati archiepiscopi Gnesnensis, die tandem hodierna in ecclesia cathedrali Cracoviensi, adveniente Celsissimo loci ordinario absolutaque missa lecta coram maiori altari, accinente musica, Celsissimus etiam consecratus, absoluta missa ad altare Crucifixi Domini, in eodem paramento albi coloris mitratus accessit maius altare, ibique iuramentum coram Celsissimo loci ordinario iuxta Pontificalem Romanum explevit, tandem distinctorium seu pallium archiepiscopalis dignitatis accepit, tandem intronisatus in throno a cornu Evangelii maioris altaris, qui nomine reverendissimi capituli a Perillustri et Reverendissimo Mathia Josepho a Łubna Eubinski, archidiacono Cracoviensi, disertissima oratione salutatus, tandem a Patribus Societatis Jesu tum a Patribus Scholarum Piarum cum panegyrycis oblatis eodem honore dignatus est”. Zob. również AKMK, AOff 182, k. $743 v$ (,,Mercurii XXIX Octobris [1749]. Hac die audientia causarum non fuit servata, ob praecedentem solemnem consecrationem Illustrissimi et Reverendissimi Domini Adami Ignatii comitis in Liptow et Orawa de Komorowy Komorowski, archiepiscopi Gnesnensis, Cracoviae, in ecclesia Beatissimae Mariae Virginis”)

Anno 1749, die Martis 28. Octobris, ipso festo Sanctorum Simonis et Judae Apostolorum, praeparatis praeparandis in ecclesia archipresbyterali Beatissimae Virginis Mariae in Circulo Cracoviensi ad actum consecrationis Celsissimi Adami Komorowski, nominati archiepiscopi Gnesnensis, praepositi Cracoviensis, hora septima de mane, cum duobus Illustrissimis episcopis conconsecratoribus, cum solita sua assistentia, ad palatium Celsissimi loci ordinarii discessit, ibique praemissis ab utinque disertis sermonibus signum distinctivum Aquilae Albae a Celsissimo loci ordinario consecratore accepit, et simul cum eodem ad ecclesiam consecrationi destinatam discessit in assistentia Illustrissimorum episcoporum conconsecratorum tum in numerosissima magnorum hospitum frequentia comitante et antecedente, ingressi quoque ecclesiam facta adoratione Sanctissimi Sacramenti, Celsissimus loci ordinarius consecrator accessit ad maius altare, ascendensque tronum sibi a cornu Epistolae paratum, Celsissimus vero nominatus in capella sua, paramenta acceperunt. Item conconsecratores: primus Illustrissimus Venceslaus Sierakowski, episcopus Premisliensis, secundus Illustrissimus [k. 40v] Michaël Kunicki de Magna Kunice, episcopus Arsinoensis, suffraganeus Cracoviensis, tertius conconsecrator Illustrissimus Dobinski, suffraganeus Gnesnensis, quartus conconsecrator Illustrissimus Martinus Załuski, suffraganeus Plocensis, tum reverendissimi domini capitulares praelati et canonici ac Franciscus Petrykowski, abbas Beatissimae Virginis Mariae de Peroszlo[?], et Woznicki, prae-

${ }^{67}$ Por. Wiadomości, s. 304 (tamże przyp. 50); Przybyszewski, s. 82. Zob. także Szostkiewicz, s. 486; Dola (I), s. 264, nr 62; Nitecki, kol. 209-210; Szczepaniak, Duchowieństwo diecezji krakowskiej w XVIII wieku, s. 614. 
positus infulatus Tarnoviensis, in sacrario apparatu entes infulis ornati tum caeteri iuxta competentiam et dignitatem praeparati processionaliter cum cruce ad altare maius Celsissimum nominatum deduxerunt hoc modo. Primo clerus, deinde Reverendissimi abbas et infulatus praepositus, deinde reverendissimum capitulum, tunc Illustrissimi episcopi, super [sic!] quos Celsissimus nominatus progressi sunt, ibique facta reverentia Celsissimo consecratori, ante medium altaris sedenti, consecratio debito ordine caepta et feliciter peracta iuxta praescriptum Pontificalis Romani, post quam disertissimo sermone Celsissimus nominatus gratus egit Celsissimo consecratori, qui vice versa sermone eleganti respondit; post haec tam Celsissimus consecrator quo Celsissimus nominatus thronos suos conscenderunt, ibique concionem in laudem Celsissimi nominati audierunt, per Peillustrem et Reverendissimum Andream Ankwicz, canonicum cathedralem Cracoviensem, suavissimo ore loquentem, qua finita ad hospitibus palatium Celsissimi loci ordinarii regressi.

\section{3}

Korytowski Józef biskup (Gniezno)

sakra 27 XI 1785 (niedziela) • Poznañ ${ }^{68}$

AAPzn, ASO 13, k. $18 r$

Anno 1785, Dominica prima Adventus, die scilicet 27. Novembris, in ecclesia cathedrali Posnaniensi, infra missarum solemnia, [suffraganeus Posnaniensis Franciscus Rydzyński] consecravit in episcopum Martyropolitanum, de suffraganeatu metropolitano Gnesnensi provisum, Illustrissimum et Reverendissimum Josephum Korytowski, canonicum metropolitanum Gnesnensem et cathedralem Posnaniensem, in assistentia duorum episcoporum, unius Ludovici de Mathy, Thanasiensis, et alterius Josephi Szaiowski, Laradensis.

\section{4}

Kos (Koss) Adam biskup (Chełmża)

sakra 14 VII 1658 (niedziela) $•$ Smardzewice ${ }^{69}$

ADWt, 3-ASWtP 5(97cz), k. 46v. Zob. również ASV, Segreteria di Stato. Polonia, Add. 5, b.p. (iuramentum fidelitatis Adama Kosa z daty: b.m., 15 VII 1658, opatrzone adnotacja notariusza authoritate apostolica Lukasza Przewtockiego, scholastyka wolborskiego i kanonika kruszwickiego: „Propria in persona constitutus Illustrissimus et Reverendissimus Dominus, Dominus Adamus Koss, Dei et Apostolicae Sedis gratia episcopus Culmensis et Pomesaniae, haberet et teneneret in manibus suis iuramentum supra exaratum [...], in manibus Illustrissimi principis et Reverendissimi

${ }^{68}$ Por. Korytkowski, t. 2, s. 299, 639 przyp. 1. Zob. także Szostkiewicz, s. 489; Nitecki, kol. 215-216 (mylna forma nazwiska Korytkowski).

${ }^{69}$ Zob. Szostkiewicz, s. 490; Dola (I), s. 260, nr 37; Nitecki, kol. 216. 
Domini, Domini Casimiri Floriani ducis in Klewan Czartoryski, dicta gratia episcopi Vladislaviensis et Pomeraniae, in actu consecrationis sui, per eundem ad tactum Evangeliorum praestitum [...]. Actum et datum in Curia Smarzewicensi, residentia illustrissimorum dominorum episcoporum Vladislaviensium, anno, die, mense quibus supra, praesentibus Perillustribus et Admodum Reverendis ac Generosis Dominis Matthiae Bÿstram, archidiacono Culmensi, Hieronimo Kęmpicki, Vladislaviensi canonico, decano Cureloviensi, Petro Lichniewicz, canonico et officiali Volboriensi”)

Anno quo supra [1658], die 14. Julii, ipso festo Sancti Bonaventurae Episcopi [et] Confessoris, Perillustris et Reverendissimus Dominus Stanislaus Domaniewski, Dei et Apostolicae Sedis gratia episcopus Margaritensis, suffraganeus Vladislaviensis et Pomeraniae, custos Volboriensis, una cum Illustrissimo principe et Reverendissimo Domino, Domino Casimiro Floriano duce [de] Clewan Czartoryski, Dei et Apostolicae Sedis gratia episcopo Vladislaviensi et Pomeraniae atque Perillustri et Reverendissimo Domino Stanislao Święcicki, eadem qua supra gratia episcopo Spigacensi, suffraganeo Samogitiae, archidiacono Vladislaviensi et officiali Gedanensi, consecravit Illustrissimum et Reverendissimum Dominum, Dominum Adamum Kos in episcopum Culmensem et Pomeraniae in ecclesia conventuali Sanctae Annae Ordinis Sancti Francisci, spectante populo utriusque sexus ad divina et specialiter pro actu congregato etc. etc., idque post villam Szmardzevice dictam episcopalem.

\section{5}

Krasiński Franciszek biskup (Kraków)

sakra 6 I 1573 (wtorek) $\cdot$ Warszawa ${ }^{70}$

AKMK, AEp 30, k. 20v.

Sexta dies eius mensis [Januarii], qua feriae Epiphaniarum celebrabantur, in ecclesia collegiata Varsoviensi, [...] Reverendissimus Dominus Franciscus Crassinski, confirmatus episcopus Cracoviensis, per Reverendissimum Dominum Jacobum Uchanski, archiepiscopum Gnesnensem, praesentibus aliis reverendissimis dominis episcopis et suffraganeis, ad episcopatum Cracoviensem est consecratus.

66

Kraszkowski Franciszek Józef biskup (Gniezno) sakra 4 II 1720 (niedziela) $・$ Warszawa ${ }^{71}$

${ }^{70}$ Zob. Szostkiewicz, s. 493; Dola (I), s. 273, nr 46; Nitecki, kol. 225-226.

${ }^{71}$ Por. Korytkowski, t. 2, s. 363; Sarna, t. 2, s. 398. Zob. także Szostkiewicz, s. 493; Nitecki, kol. 227. 
AAPrzem, 69, k. 9r (Consecratio Reverendissimi Domini Kraszkowski in episcopum Dardaniensem)

Anno, quo supra [1720], die vero quarta mensis Februarii, quae erat Dominica Sexagesimae, in ecclesia collegiata Varsaviensi, sua Illustrissima Celsitudo [mowa o biskupie przemyskim Krzysztofie Janie Szembeku], intra missarum solennia, assistentibus Illustrissimis ac Reverendissimis Dominis Joanne Tarło, Kiioviensi, et Stephano Rupniewski, Camenecensi, episcopis, vigore literarum et commissionis apostolicae, Reverendissimum Dominum Franciscum Josephum Kraszkowski, archidiaconum Gnesnensem, praepositum Calissiensem, in episcopum Dardanensem et suffraganeum Gnesnensem consecravit atque ab eodem circa actum eiusmodi consecrationis suae iuramentum fidelitatis Sanctae Sedi Apostolicae, iuxta formam literarum apostolicarum [...], in manibus propriis recepit.

$$
\text { AAPzn, ASO 7, k. } 56 r
$$

Anno Domini millesimo septingentesimo vigesimo, mense Februario, die sexta [sic!], quae erat Dominica Septuagesimae, Varsaviae, in ecclesia collegiata Sancti Joannis Baptistae, consecranti Illustrissimo et Reverendissimo Domino Christophoro Szembek, episcopo Praemisliensi, Illustrissimum Franciscum Kraszkowski, suffraganeum Gnesnensem, in episcopum Dardaniensem, tanquam conconsecrans episcopus [Posnaniensis] Illustrissimus Dominus [Joannes Joachimus Tarło] abstitit una cum Illustrissimo Domino Stephano Rupniewski, protunc episcopo Camenecensi.

\section{7}

Kretkowski Feliks Ignacy biskup (Chełmża)

$$
\text { sakra } 31 \text { X1723 (niedziela) • Warszawa }{ }^{72}
$$

AAPzn, ASO 7, k. 56v. Zob. także ADPelp, AKKCh, A 49, k. 2r (sesja kapituly katedralnej chetmińskiej 18 X 1723: „Illustrissimus et Reverendissimus suffraganeus archidiaconus praesentavit legitque litteras ab Illustrissimo et Reverendissimo episcopo Culmensi et Pomesaniae nominato et iam confirmato, in quibus expressam gratiarum actionem pro susceptione sui ad gremium et ad stallum episcopale remonstravit totumque capitulum paterno affectu prosecutus, petiit iisdem literis, quatenus ad actum consecrationis e medio venerabilis capituli deputentur [...] ad assistendum Illustrissimo ac Reverendissimo consecrando Perillustrem Dominum Franciscum Czapski, scholasticum, et Perillustrem Dominum Florianum Waliszewski, canonicum”); $k$. $2 v$ (j.w.: „,Perillustris Franciscus Czapski, scholasticus cathedralis, ad latus Illustrissimi et Reverendissimi episcopi Culmensis et Pomesaniae deputatus, pro assistentia in consecratione Varsaviae peragenda electus [est]. [...]. Pro consecratione Illustrissi-

${ }^{72}$ Por. Korytkowski, t. 2, s. 370. Zob. również Szostkiewicz, s. 493; Dola (I), s. 260, nr 44; Nitecki, kol. 227-228; Wiadomości, s. 306; T. Sławiński, Kretkowscy i ich dzieje od połowy XIV wieku, Warszawa $2011^{2}$, s. 350 (całość biogramu - s. 347-355 § 7.2). 
mi et Reverendissimi Felicis Kretkowski in episcopum die 31. mensis Octobris [1723] peragenda, ad requisitionem eiusdem Illustrissimi et Reverendissimi supramemorati per literas ad Perillustrem Dominum Florianum Waliszewski exaratas, libentissime misit pastorale venerabile capitulum Illustrissimi olim piae memoriae Joannis Casimiri de Alten Bokum, episcopi Culmensis et Pomesaniae, antecessoris sui, tum et casulam olim Illustrissimi et Reverendissimi Koss, nominati episcopi Culmensis et Pomesaniae, pretiosam, albi coloris, ecclesiae cathedrali oblatam, per manus Perillustris Domini Francisci Czapski eidem Illustrissimo consecrando obtulit cum obligatio Perillustri domino scholastico imposita, haec omnia quam optime conservandi ad manus Illustrissimis reddendi, recipiendi et venerabile capitulo restituendi"); $k$. $3 r$ (sesja kapituly 12 XI 1723: „,Perillustris Dominus Franciscus Czapski redux Varsavia retulit venerabili capitulo iam peractam esse consecrationem Illustrissimi et Reverendissimi Domini Felicis Kretkowski, episcopi Culmensis et Pomesaniae, significavitque gratam fuisse eidem Illustrissimo assistentiam per se tanquam delegatum venerabili capitulo expeditam in actu praemisso")

Anno Domini millesimo septingentesimo vigesimo tertio, mense Octobri, die trigesima prima, quae tunc fuit Dominica vigesima quarta post Pentecostes, Varsaviae, in ecclesia Patrum Teatinorum, consecranti Excellentissimo, Illustrissimo et Reverendissimo Vincentio Santino, archiepiscopo Trapezuntino, Sanctissimi Domini Nostri in Regno Poloniae nuntio, Illustrissimum et Reverendissimum Felicem Kretkowski, referendarium Regni, praepositum Gnesnensem, in episcopum Culmensem, tanquam conconsecrans Illustrissimus et Reverendissimus Dominus episcopus [Posnaniensis Joannes Joachimus Tarło] abstitit una cum Illustrissimo Adamo Rostkowski, episcopo Philadelphiensi, suffraganeo Luceoriensi.

\section{8}

Kromer Marcin biskup (Warmia)

sakra 6 XII 1579 (niedziela) • Warszawa

AAWO, AB A 3, k. 469v (Consecratio Reverendissimi Domini, Domini Martini Cromer). Zob. również AAWO, AB H 42, s. 90: „, A Stanislao Karnkowski, episcopo Vladislaviensi, in comitiis generalibus Varsaviensibus consecratus est in episcopum die $6^{\text {ta }}$ mensis Decembris anno 1579no". Ponadto: AAWO, AB D 36, k. 47r (gdzie o pierwotnie przewidywanym na miejsce sakry Wolborzu); AAWO, AB H 37, s. 57 (,,Anno 1579므, die 6 $6^{\text {ta }}$ Decembris Varsaviae episcopus consecratus”)

Cum Reverendissimus in Christo Pater ac Dominus, Dominus Martinus Cromerus, Illustrissimo et Reverendissimo Domino, Domino Stanislao Hosio, S.R.E. cardinali et episcopo Varmiensi maiorique poenitentiario mortuo, in episcopatu Varmiensi ex praescripto Pii V. Pontificis Maximi successisset, sexta dies mensis Decembris anno Domini 1579 Varsaviae in templo Bernhardinorum, dum comitia Regni ibidem celebrarentur, a Stanislao Carnicovio [sic!], Vladislaviensi episcopo, a[d]stantibus Petro Kostka, Culmensi, et Adamo Pylchowsky, Chelmensi, epi-

${ }^{73}$ Zob. Szostkiewicz, s. 494; Dola (I), s. 295, nr 23; Nitecki, kol. 228. 
scopis, praesentibusque aliquot aliis episcopis cum viro ornatissimo Joanne Andrea Caligario, nuncio apostolico, sacris episcopalibus iniciatus est, pro honestate etiam eam celebritatem pientissimo et praesentantissimo rege Stephano, una cum frequenti caterva aliorum senatorum suorum.

\section{9}

Kunicki Michat Ignacy biskup (Kraków) sakra 23 III 1727 (niedziela) $\cdot$ Warszawa ${ }^{74}$ AAPzn, ASO 7, k. $56 r$

Anno Domini 1727, mense Februario, die 23. Martii, quae erat Dominica quarta Quadragesimae, Varsaviae, in ecclesia Patrum Capucinorum, consecranti Celsissimo principi Illustrissimo et Reverendissimo, Excellentissimo Domino Theodoro a Potok Potocki, archiepiscopo Gnesnensi, primate Regni et Magni Ducatus Lithuaniae, legato nato, abbatiae Tynecensis perpetuo administratore, Illustrissimum Michaelem Kunicki in episcopum Aaronensem [recte Arsinoensem], tanquam [con]consecrans fuit Illustrissimus et Reverendissimus Joannes Tarło, episcopus Posnaniensis, cum Illustrissimo et Reverendissimo Andrea Załuski, episcopo Plocensi.

Kurdwanowski Jan Franciszek biskup (Warmia)

sakra 17 XII 1713 (niedziela) $\bullet$ Dobre Miasto ${ }^{75}$

AAWO, AK Acta Cap.13, k. 229v (sesja kapituly 15 XII 1713)

Praesentate sunt literae domini cancellarii Suae Illustrissimae Celsitudinis $[t j . b i$ skupa warmińskiego Teodora Andrzeja Potockiego] ad perillustrem dominum cantorem [capituli Varmiensis] scriptae, quibus denuntiat consecrationem illustrissimi suffraganei Varmiensi in ecclesia collegiata Guttstadiensi proxime seguenti die Dominica futura. Ad quem actum deputati sunt Perillustres Domini Łaszewski et Zaleski, cum praecautione, ne praecedentiam canonicis collegiatae illius ecclesiae, si forte eam utpoti in propria sua ecclesia praetenderint, cedant.

${ }^{74}$ Zob. Szostkiewicz, s. 496; Nitecki, kol. 236; Wiadomości, s. 306-307 (tamże przyp. 59); Przybyszewski, s. 86-88; Szczepaniak, Duchowieństwo diecezji krakowskiej w XVIII wieku, s. 625.

${ }^{75}$ Por. Polonica, s. 181, nr 112. Zob. także Szostkiewicz, s. 496; Nitecki, kol. 236; Przybyszewski, s. 88-89. 
$A A W O, A B H 20$, s. 12

Anno 1713, Decembris 17., quae fuit Dominica III. Adventus, in suffraganeum Varmiensem ordinatus [est] Reverendissimus Dominus [Joannes] Kurdwanowski, canonicus Frauenburgensis.

71

Kurski Maciej Marian biskup (Baków - Poznań)

sakra 3 VIII 1651 (czwartek) • Lowicz $^{76}$

APBKr, W-26, s. 214-215. Zob. również tamże, RGP-k-47, t. 30, s. 105 (,,Sacratur in episcopum ab Illustrissimo et Reverendissimo Domino Mathia Łubieński, primate ac primo Regni Poloniae principe, archiepiscopo Gnesnensi, adstantibus Reverendissimis Adriano Grodecki, Gneznensi, ac Tolibowski, Plocensi, suffraganeis, Lovicii, anno 1651 ").

Anno Domini 1651 Reverendissimus Dominus Marianus Kurski bullas a Sanctissimo Domino Nostro Innocentio X pro consecratione sua obtinuit et die 3 . Augusti anni supradicti in episcopum consecratus est ab Illustrissimo et Reverendissimo Domino Matthia Lubienski, archiepiscopo Gnesnensi, legato nato, Regni Poloniae primate primoque principe, intra missarum solemnia coram altari Capellae Węzykovianae circa ecclesiam collegiatam Beatae Mariae Virginis Loviciensis, assistentibus episcopis Reverendissimo Domino Adriano Grodecki, episcopo Theodosiensi, suffraganeo Gnesnensi, et Reverendissimo Domino Alberto Tolibowski, episcopo Lacedaemonensi, suffraganeo Plocensi.

72

Lascaris (Laskary) Jerzy Maria biskup ([Łuck])

sakra 29 VI 1741 (czwartek) • Otyka

AGAD, Dziat VI, II-80a, s. 1132-1133

Die 29. Junii 1741 [Ołyka]. Z rana zaczęła się konsekracja Jmci Xiędza Laskarego, infułata ołyckiego, na biskupstwo zenopolitańskie. Konsekrował go Jmć Xiądz biskup łucki, assistentes consecrationis Ichmościowie Xięża sufragan kamieniecki i koadiutor ormiański, in praesentia Ichmościów Xięży Wołodkowicza, Graeci

${ }^{76}$ Zob. Szostkiewicz, s. 496; Nowacki, t. 2, s. 188, nr 24; Dola (I), s. 257, nr 7; Nitecki, kol. 237-238. Nadto Annales Minorum seu trium Ordinum a S. Francisco institutorum, t. 30 - 1651-1660, ed. A. Chiappini, Florentiae 1951, s. 60-61, nr LXXVIII; K. R. Prokop, Konsekracja biskupa Macieja Mariana Kurskiego. Przyczynek do biografii poznańskiego sufragana, „Kronika Miasta Poznania", 64 (1996) nr 3, s. 236-242.

${ }^{77}$ Por. Wiadomości, s. 307. Nadto „Diario Ordinario”, nr 2188 z 19 XII 1795, s. 14-16. 
ritus [eparchy] [s. 1133] chełmskiego, i Ulewicza, nominata sufragana kijowskiego. Baryłki nieśliśmy ja [autorem zapiski Michał Kazimierz Radziwitt] z Jmcią Panem [Maciejem Mycielskim], kasztelanem poznańskim, chleb książę Stanisław Radziwiłł, wojewodzic nowogrodzki, z Jmcią Panem Skaławskim, kasztelanicem gnieźnieńskim, świece zaś nieśli dwaj synowie moi. Przy Te Deum laudamus ognia garnizon mój tutejszy po trzykroć dawał i z armat na wałach stojących. Tych wszystkich na obiedzie traktowałem u siebie przy hucznym z dział biciu.

\section{3}

Leski Wojciech Stanisław biskup (Chełmża)

sakra $7 X 1747($ sobota $) \cdot$ Elblag $^{78}$

ADPelp, C 52a, karta tytułowa.

Illustrissimus ac Reverendissimus Dominus, Dominus Adalbertus Stanislaus de Liesclicht seu a Leszcze Leski, abbas Pelplinensis, commissarius ac vicarius generalis Ordinis Cisterciensis per Poloniam et Magnum Ducatus Lithvaniae, a Serenissimo Domino, Domino Augusto III. Poloniae rege nominatus [episcopus Culmensis et Pomesaniae], [...] a Celsissimo principe Adamo de Grabow Grabowski, episcopo Varmiensi et Sambiensi, terrarum Prussiae praeside, die septima mensis Octobris anno Domini millesimo septingentesimo quadragesimo septimo, in ecclesia parochiali Elbingensi extitit consecratus, accepta prius [...] per Perillustrem et Reverendissimum Dominum Fabianum Pląskowski, archidiaconum Pomesaniensem, canonicum cathedralem Culmensem, officialem generalem dioecesis Pomesaniensis [...], suum mandatarium, bonorum dicti episcopatus canonica possessione.

\section{4}

Leszczyński Rafał biskup (Przemyśl - Płock)

sakra 11 IX 1524 (niedziela) • Ptock ${ }^{79}$

ADPt, AEp 12(3[14]), s. 102

Anno quo supra [1524], die vero Solis XI Septembris, Reverendissimus in Christo Pater et Dominus, Dominus Raphael [Leszczyński], Dei gratia electus

${ }^{78}$ Por. Wiadomości, s. 307 (tamże przyp. 61); Korytkowski, t. 3, s. 557. Zob. także Szostkiewicz, s. 498; Dola (I), s. 260, nr 48; Nitecki, kol. 244; Frydrychowicz, Geschichte der Cistercienserabtei Pelplin, s. 114-115, nr 37.

${ }^{79}$ Por. Sarna, t. 1, s. 93 („Zdaje się, że jeszcze po instalacji [na biskupstwo] długi czas nie był konsekrowany na biskupa, gdyż akta tak kapituły przemyskiej, jak i kapituły płockiej, nazywają go electum et confirmatum episcopum Premisliensem"). Zob. Szostkiewicz, s. 499; Dola (I), s. 284, nr 40 oraz s. 289, nr 16; Nitecki, kol. 246. 
confirmatus [Plocensis], per Reverendissimos Dominos Mathiam [Drzewicki], episcopum Wladislaviensem, Alexandrum [Myszczyński], suffraganeum Wladislaviensem, [et] suffraganeum Plocensem Petrum [Lubart], in ecclesia cathedrali Plocensi consecratus est.

\section{5}

Leżeński Kazimierz Benedykt biskup (Warmia) sakra 17 IX $1695\left(\right.$ sobota) • [Lidzbark Warmiński] ${ }^{80}$

AAWO, AK Ab 22, k. 304r (list biskupa K.B. Leżeńskiego do warmińskiej kapituty katedralnej z daty: In Cechren, die 17. Decembris 1697). Zob. również AAWO, AB H 37, s. 81, gdzie w opisie pogrzebu w dniu 13 IX 1695 kanonika Jana Filipa Pfeiffera widnieje informacja, że eksporta odbyła sie , ,in assistentia trium episcoporum, nempe domini loci ordinarii [tj. Jana Stanistawa Zbąskiego], Domini Nicolai Poplawski, episcopi Livoniensi, et Domini Benedicti Lesenski, episcopi Hymerunensis, suffraganei Varmiensis", co wskazuje pośrednio na grono uczestników późniejszej o cztery dni sakry ostatniego z wymienionych)

Munus consecrationis die 17. Septembris anno 1695 obtinuerim.

76

Leżeński Tomasz biskup (Chełm/Krasnystaw - Łuck)
sakra 2 II 1659 (niedziela) $・$ Kielce (II $^{81}$

AKMK, LOrd 4, k. $164 v$.

Anno quo supra [1659], Dominica quarta post Epiphaniam, ipso festo Purificationis Beatissimae Mariae Virginis, quae fuit dies secunda mensis Februarii, Reverendissimus [Nicolaus Oborski, episcopus Laodicensis et suffraganeus Cracoviensis], asstitit [=adstitit] consecrationi in ecclesia collegiata Kielcensi Illustrissimi et Reverendissimi Domini, Domini Thomae Lezin[s]ki, episcopi Chelmensis et abbatis Vąchocensis.

${ }^{80}$ Zob. Szostkiewicz, s. 499; Nitecki, kol. 248

${ }^{81}$ Por. Pawelec, cz. 6, s. 394, nr 35. Zob. także Szostkiewicz, s. 500; Dola (I), s. 258, nr 28; Nitecki, kol. 248-249. 
Lintfari Marcin biskup (Żmudź/Miedniki)

sakra 18 XI $1492\left(\right.$ niedziela) $・$ Rzym $^{82}$

ASV, Camera Apostolica, Libri Formatarum 11, k. 22r (Munus consecrationis pro Domino Martino, episcopo Mednicensi)

Universis et singulis [...] [notum facimus], quod Reverendus in Christo Pater Dominus Joannes [de Rubeis], episcopus Alatrinensis, in Romana Curia residens, ex papali commissione [...] die Dominica XVIII mensis Novembris, assistentibus Reverendis Patribus Dominis Guilhelmo [de Balania], Sagonensi, et Donato [de Torre], Veglensi, episcopis, in capella Sanctissimi Trinitatis de Urbe, infra missarum sollemnia, Reverendo in Christo Patre Domino Martino Jo[annis], electo Mednicensi, munus consecrationis rite impendit ipsumque Dominum Martinum electum solemniter consecravit iuxta formam et consuetudinem Sacrae Romanae Ecclesiae in talibus servari solitas. [...] Datum Romae, in Camera Apostolica, anno Domini MCCCCLXXXX[II], die XXII dicti mensis, anno primo.

\section{8}

Lipnicki Wojciech biskup (Kraków) sakra 22 VII 1646 (niedziela) • Kraków ${ }^{83}$

AKMK, LOrd 4, k. $1 r$-v. (gdzie $w$ dalszej części zapiski widnieje nadto informacja: „Consecratus in presbyterum anno Domini 1605, Sabbato pro Quarttuor temporibus S. Luciae, quae fuit dies 17. Septembris").

Reverendissimus Adalbertus Lipnicki, Dei et Apostolicae Sedis gratia episcopus Laodicensis, suffraganeus, canonicus, vicarius in spiritualibus et officialis generalis Cracoviensis, [...] anno Domini 1646, die Solis 22. mensis Julii, in ecclesia cathedrali Cracoviensi, per Illustrissimos et Reverendissimos Dominos Petrum Gembicki, Cracoviensem episcopum, ducem Severiae, Andream Lesczynski, Kiioviensem [recte Camenecensem], [et] Andream [recte Stanislaum] Pstrokonski, Chelmensem, episcopos, consecratus est praesente Joanne de Torrez, archiepiscopo Adranopolitano, nuncio apostolico, anno aetatis suae 65 , presbiteratus vero 41 .

\section{9}

Lipski Jan arcybiskup (Chełmża - Gniezno)

sakra 14 IX 1636 (niedziela) $\bullet$ Lowicz $^{84}$

${ }^{82}$ Por. G. Błaszczyk, Diecezja żmudzka od XV do początku XVII wieku. Ustrój, Poznań 1993, s. 47-49, nr XI. Także Szostkiewicz, s. 511; Dola (I), s. 281, nr 10; Nitecki, kol. 250-251.

${ }^{83}$ Zob. Szostkiewicz, s. 500; Nitecki, kol. 251.

${ }^{84}$ Zob. Szostkiewicz, s. 501; Dola (I), s. 260, nr 32; Nitecki, kol. 252; Przybyszewski, s. 95-97. 
ADPelp, C 12, k. 13v-14v

Acceptis bullis, reliqum erat, ut Sua Celsitudo maturaret consecrationem atque ingressum [k. 14r] id quod sui desiderabat. Cum vero ea tarditas expeditionis Romanae evenisset, Suae Celsitudini facultatem consecrationis apud Illustrissimum episcopum Cracoviensem expediendae, qui sub id tempus morbis podagricis et chyragricis [hydrogricis] graviter conflictabatur, invitante, et suam operam offerente Illustrissimo et Reverendissimo Domino Joanne Węzyk, archiepiscopo Gnesnensi, Lovicium sese cum numeroso propinquorum et amicorum famulorumque comitatu ad diem XIII Septembris [1636] contulit, ubi Illustrissimi quoque Domini episcopi, fratres Vladislaviensis et Plocensis, invitatu suo aderant, etsi iam ante suffraganeos duos Gnesnensem et Posnaniensem invitaverat, qui itidem adventum Suae Celsitudinis Lovicii praestolabantur. Solemni igitur ritus, inauguratio et consecratio Suae Celsitudinis peracta est die XIV Septembris [1636], in templo primario Divae Virginis, in praesentia quinque episcoporum, duorum palatinorum: Lanciciensis [ $k .14 v$ ] ac Ravensis, trium castellanorum: Ravensis, Sochacoviensis, Gostinensis, et magna frequentia illustrium virorum, quod omnes bino epulo illustrissimus dominus archiepiscopus in arce superbe et splendide excepit tractavitque, obviam antea extra arcem Suae Celsitudinis progressus et eximiam humanitatem atque favorem testatus.

80

Lipski Jan Aleksander biskup (Łuck - Kraków), kardynat
sakra 25 V 1732 (niedziela) $・$ Warszawa ${ }^{85}$

AKapMK, LA 36, s. 5.

Anno a partu Virginis 1732, die 25. Maii, quae erat Dominica infra Octavam Ascensionis Domini, in ecclesia insignis collegiata Varsaviensis Sancti Joannis Baptistae, per Celsissimum, Illustrissimum et Reverendissimum Dominum, Dominum Theodorum Potocki, archiepiscopum Gnesnensem, primatem Regni Poloniae, assistentibus Illustrissimis et Reverendissimis Dominis, Dominis Andrea Załuski, Plocensi, Nicolao [recte Adamo] Wessel, Livoniae, episcopis, Adamo Rostkowski, Luceoriensi, Josepho [recte Matthiae] Sołtyk, Culmensi, suffraganeis, aliisque praelatis, praesente et spectante Serenissimo Augusto Secundo, rege Poloniae, plurimis principibus, senatoribus Regnique ministris, nec non magna numerositate statuum votive omnium cum plausu consecratus [est episcopus Luceoriensis Joannes Alexander Lipski].

${ }^{85}$ Por. Wiadomości, s. 308 (tamże przyp. 62). Zob. także Szostkiewicz, s. 501; Dola (I), s. 280, nr 38; Nitecki, kol. 252; Przybyszewski, s. 95-97; Polonica, s. 181, nr 118. 
BN, BOZ 941, s. 88. Zob. również ADPelp, AKKCh, A 16, s. 110 (nr 2)

Die 25. Maii [1732] Celsissimus primas consecravit Illustrissimum vicecancellarium Lipski, episcopum Luceoriensem; assistentes episcopi erant Illustrissimi Załuski, Plocensis, Wessel, Livoniae praesules, Rostkowski, Luceoriensis, Sołtyk, Culmensis suffraganei.

\section{1}

Lipski Konstantyn Samuel arcybiskup (Lwów)

sakra 28 IX 1681 (niedziela) • Kraków ${ }^{86}$

AKMK, AEp 67, k. 14r-v (Solis XXVIII. Septembris [1681], Cracoviae. Consecratio Constantini Lipski, archiepiscopi Leopoliensis). Zob. także AJG, 535, s. 191 (gdzie w opisie dopetnionego 27 IX 1681 ingresu nowego ordynariusza krakowskiego Jana Małachowskiego, zanotowano, iż ,sequenti die actus consecrationis Illustrissimi et Reverendissimi Domini Constantini Samuelis Lipski, archiepiscopi Leopoliensis, impeditus fuit")

Illustrissimus et Reverendissimus Dominus Stanislaus Hiacynthus Swięcicki, Dei et Apostolicae Sedis gratia episcopus Chełmensis, Dominica XVIII post Pentecostes, die $28^{\text {va }}$ mensis Septembris anno 1681, de speciali facultate Illustrissimi et Reverendissimi Domini Joannis Małachowski, episcopi Cracoviensis, ducis Severiae, pontificalia exercens Divina gratia suffragante pro officii sui episcopalis munere vigore literarum apostolicarum sibi legitime praesentatarum et publice lectarum, Illustrissimum et Reverendissimum Dominum Constantinum Lipski, presbyterum, abbatiae Andreoviensis Ordinis Cisterciensis perpetuum administratorem, Sandomiriensem [et] Vielunensem canonicum, per Sacram Regiam Maiestatem nominatum et per Sanctam Sedem Apostolicam provisum archiepiscopum Leopoliensem, in ecclesia cathedrali Cracoviensi, intra missarum solennia, in magna frequentia hominum diversi status et conditionis, assistentibus Illustrissimo et Reverendissimo $[k .14 v]$ Domino Stanislao Woienski, episcopo Camenecensi, [et] Perillustri et Reverendissimo Domino Nicolao Oborski, episcopo Laodicensi, suffraganeo Cracoviensi, servatis omnibus et singulis solemnitatibus et ceremoniis in Pontificali Romano de consecratio episcoporum praescriptis et expressis, et alias, canonice ritu consecravit, prout in instrumento consecrationis per Admodum Reverendum Thomam Najkowski, philosophiae doctorem, publicum sacra authoritate apostolica et venerabilis capituli Cracoviensis notarium desuper confecto et extradito et in actis notariatus ipsius plenius continentur.

${ }^{86}$ Por. Krętosz, Organizacja archidiecezji lwowskiej, s. 71, nr 26. Zob. także Szostkiewicz, s. 501; Dola (I), s. 277, nr 19; Nitecki, kol. 252-253. 
AKMK, LOrd 5, k. 122v-123r.

Perillustris et Reverendissimus Dominus [Nicolaus Oborski, episcopus Laodicensis et suffraganeus Cracoviensis], die 28. Septembris [1681] consecravit in ecclesia cathedrali Cracoviensi Illustrissimum et Reverendissimum Dominum, Dominum Constantinum Lipski in archiepiscopum Leopoliensem.

82

Lipski Mateusz Melecjusz biskup (Mohylów [Połock] - Mińsk) sakra 5 IX [24 VIII st.st.] 1824 (niedziela) • Wilno ${ }^{87}$

ASV, Archivio Concistoriale, Processus Consistorialis, vol. 230, k. 250r-v. Zob. również tamże, k. $223 r$ (,, Testimonium piae memoriae Thaddei Kundzicz, episcopi Anastasiopolitani, suffraganei Trocensis [...] anno 1824, mense Augusti, 24. die extraditum, ex quo constat: episcopum [Mattheum] Lipski a superius memorato episcopo Kundzicz, assistentibus piae memoriae Adamo Corvino Kossakowski, episcopo Limirensi, suffraganeo Curoniensi, nec non Adriano Hołownia, episcopo Orsensi, suffraganeo metropolitano Vilnensi ritus Graeco-Uniti, servatis servandis anno Domini 1824, mense Augusti, 24. die, munus consecrationis in ecclesia cathedrali Vilnensi rite suscepisse”).

[Nos] Thaddaeus Kundzicz, Dei et Apostolicae Sedis gratia episcopus Anastasiopolitanus, suffraganeus Trocensis, canonicus cathedralis Vilnensis [...], universis et singulis [...] significamus: exhibitum nobis fuisse [...] transumptum bullarum apostolicarum [...] provisionem episcopatus Aureopolitani in se continentium, favore Illustrissimi ac Reverendissimi Matthaei Lipski, suffraganei Polocensis [...]. Post cuius quidem transumpti praesentationem, requisiti fuimus ab Illustrissimo ac Reverendissimo Domino Matthaeo Lipski, quatenus in vim executionis earundem bullarum apostolicarum ipsum in episcopum Aureopolitanum promovere dignaremur. Nos [autem] [...] anno Domini millesimo octingentesimo vigesimo quarto, die vigesima quarta mensis Augusti, quae incidit in festum Translationis Sancti Casimiri, patroni Magni Ducatus Lithuaniae, in ecclesia cathedrali Vilnen$\mathrm{si}$, in $[k .250 \mathrm{v}]$ eadem ecclesia, intra missarum solemnia, assistentibus nobis Adamo Corvino Kossakowski, episcopo Limirensi, suffraganeo Curoniensi, canonico cathedrali Vilnensi, nec non Illustrissimo, Reverendissimo Domino Adriano Hołownia, episcopo Orsensi, suffraganeo metropolitano Vilnensi ritus Graeci Uniti, [...] servatis omnibus solemnitatibus in Pontificali Romano descriptis, ipsum consecravimus. [...] Datum Vilnae, anno millesimo octingentesimo vigesimo quarto, mensis Augusti, die vigesima quarta.

${ }^{87}$ Por. Polonica, s. 181-182, nr 119 (również, nr 120). Zob. także Nitecki, kol. 253. 
83

Luboradzki Antoni biskup (Płock)

sakra 25 V 1806 (niedziela) $・$ Puttusk $^{88}$

ADPt, AEp 82(95), s. 74 (Consecratio in episcopum Thanasiensem Illustrissimi Luboradzki)

[Nos] Onuphrius Caietanus, [episcopus Plocensis], universis et singulis [...] notum facimus $[\ldots]$, quod anno millesimo octingentesimo sexto, ad praesens currente, die vigesima quinta mensis Maii, scilicet ipso die Pentecosten, [...] Illustrissimo et Reverendissimo Domino Antonio Luboradzki, electo Thanasiensi, munus consecrationis in insigni collegiata Pultoviensi impendimus, ac eundem Illustrissimum et Reverendissimum Dominum Antonium Luboradzki [...] inter missarum solennia in episcopum et pastorem ecclesiae Thanasiensis [...] consecravimus [...], et huic actui assistentibus ex speciali gratia Sanctae Sedis Apostolicae, die 27. mensis Junii anni praesenti concessa, Perillustribus Reverendissimis Josepho Gogolewski, decano eiusdem collegiatae, et Petro Gościcki, cathedralis Plocensis et dictae collegiatae canonico. [...] Datum Pultoviae, die 26. mensis Maii, anno Domini $1806^{\text {to }}$.

\section{4}

Luszin (Luschin) Franciszek Ksawery arcybiskup (Trydent - Lwów - Gorycja) sakra 3 X 1824 (niedziela) $\cdot$ Salzburg ${ }^{89}$

ASV, Archivio Consictoriale, Processus Consistorialis, vol. 235, k. 17r-v.

[Nos] Augustinus, Dei et Apostolicae Sedis gratia archiepiscopus Salisburgensis, Imperii Austriaci princeps, legatus apostolicus natus, Germaniae princeps [...], fidem facimus et attestamur: nos anno Domini millesimo octingentesimo vigesimo quarto, die tertia mensis Octobris, quae dies fuit Dominica decima septima post Pentecosten, ad festum S. Rosarii Beatissimae Mariae Virginis, vi indulti apostolici Illustrissimum ac Reverendissimum Dominum Franciscum Xaverium Luschin, Sacrae Theologiae doctorem, nominatum episcopum Tridentinum, [...] assistentibus cum clementissima Summi Pontificis venia Perillustribus ac Reverendissimis Ordinis Sancti Benedicti abbatibus, Domino Alberto, abbate monasterii ad S. Petrum Salisburgi, et Domino Nicolao, abbate monasterii Michaelburani huiatis dioecesis, $[k .17 v]$ servato ritu Sanctae Romanae Ecclesiae, intra missarum solemnia, in ecclesia nostra metropolitana Salisburgi in episcopum Ecclesiae cathedralis Tridentinae consecrasse. [...] Salisburgii, [...] anno Domini 1824, tertia mensis Octobris.

\footnotetext{
${ }^{88}$ Zob. Nitecki, kol. 256.

${ }^{89}$ Por. Polonica, s. 182, nr 124 (również s. 125 oraz, nr 126 na s. 183). Także: Dola (I), s. 278, nr 29; Nitecki, kol. 258.
} 


\section{5}

\section{Laszewski Michat Remigiusz biskup (Warmia)}

sakra 6 XII 1730 (środa) • Lidzbark Warmiński ${ }^{90}$

AAWO, AB H 37, s. 106 (to samo w: AB H 37a, s. 116). Zob. także AAWO, AK V 23: „Acta pontificalia Illustrissimi et Reverendissimi Domini, Domini Michaelis Remigii Łaszewski, Dei et Apostolicae Sedis Sanctae gratia episcopi Macrensis, suffraganei et praepositi Varmiensis, ab ipso die consecrationis suae in episcopum [...], anno 1730, die 6. Decembris"; AAWO, AK Acta Cap.15, k. 337r (Capitulum prima feria $6^{\text {ta }}$ die $1^{\text {ma }}$ Decembris 1730. Invitatio pro consecratione in episcopum Illustrissimi Domini praepositi Łaszewski): „Legitur epistola Suae Celsitudinis invitatoria pro actu solemnis consecrationis in episcopum Macrensem die $6^{\text {ta }}$ currentis futuro Illustrissimi, Reverendissimi Domini prepositi Varmiensis Łaszewski; ad quam dabuntur responsoriae exprimentes unanime votum reverendissimi capituli, quo medians paterna Suae Celsitudinis desideria etiam a singulis, quantum possibile, expleantur. Datur autem octiduum interessantiae pro actu dicto abituris reverendissimis canonicis”)

Anno $1730^{\mathrm{mo}}$, die $6^{\text {ta }}$ mensis Decembris, festo Sancti Nicolai Episcopi, Heilsbergae, in ecclesia parochiali, loci ordinarius Dominus Christophorus Szembek cum omni solennitate in suffraganeum Varmiensem consecravit Dominum Michaelem Remigium Laszewski, praepositum canonicum Varmiensem, assistentibus abbate Pelplinensi et suffraganeo Culmensi Domino Sołtyk, in praesentia canonicorum cathedralis et collegiatae ecclesiarum, archipresbyterorum et multorum sacerdotum maximaeque multitudinis populi. Durarunt ceremoniae ad horam tertiam pomeridianam.

AAWO, AB H 20, s. 44. Zob. również ADPelp, AKKCh, A 16, s. 110 (nr 4)

Anno 1730, Decembris 6., Heilsbergae, in suffraganeum Varmiensem consecratus est Reverendissimus Dominus canonicus Varmiensis Michael Remigius Łaszewski a Celsissimo principe episcopo Varmiensi Domino Christophoro Szembek, praesentibus Reverendissimo Domino abbate Pölplinensi et Reverendissimo Domino Sołteck [sic!], canonico, suffraganeo [Culmensi].

\section{6}

Łącki Franciszek biskup (Włocławek)

sakra 24 VIII 1598 (poniedziatek) • Włoctawek ${ }^{91}$

ADWt, 2-ABKP 12(32), k. 596r (Consecratio in episcopum et suffraganeum Vladislaviensem Francisci Laczki)

\footnotetext{
${ }^{90}$ Por. Polonica, s. 183, nr 127. Zob. także Szostkiewicz, s. 504; Nitecki, kol. 262.

${ }^{91}$ Por. Chodyński, s. 47. Zob. także Szostkiewicz, s. 502-503; Nitecki, kol. 262-263.
} 
Anno quo supra [1598], die XXIII. Augusti, quae erat Divi Bartholomaei festum, Illustrissimus et Reverendissimus in Christo Pater ac Dominus, Dominus Hieronymus [Rozrażewski, episcopus Vladislaviensis], [...] in ecclesia cathedrali Vladislaviensi Reverendissimo Domino Francisco Laczki, eadem gratia episcopo Margarithensi, suffraganeo Vladislaviensi, assistentibus sibi [...] Reverendissimis Dominis Joanne Gniazdowski, Gnesnensi, [et] Joanne Zamoiski, Plocensi, episcopis titularibus et suffraganeis, [...] munus consecrationis impendit.

Łętowski Ludwik Stanisław biskup (Kraków/Kielce) sakra 29 VI 1845 (niedziela) • Sankt Petersburg ${ }^{92}$

AKMK, LOrd 18, k. $1^{B} r$

Ludovicus Stanislaus Kostka de Łętów Ogończyk Łętowski, Sacrae Theologiae doctor, ecclesiae cathedralis Cracoviensis custos, administrator generalis dioeceseos Kielcenso-Cracoviensi, vicarius apostolicus pro parte in Regno Poloniae sita, Ordinis Sancti Stanislai eques, ab Illustrissimo et Reverendissimo Domino Casimiro Dmochowski, protunc episcopo Mittensi et suffraganeo Curonensi, consecratore, tum assistentibus consecratoribus Illustrissimis, Excellentissimis et Reverendissimis Dominis Valentino Bończa Tomaszewski, episcopo Vladislaviensi et Calissiensi, necnon Josepho Goldmann, episcopo Sandomiriensi, [...] ritu solemni in episcopum Joppensem consecratus [est] Petropoli in ecclesia parochiali S. Catharinae, anno Domini 1845, die 29. Junii, quae fuit Dominica VII. post Pentecosten, festum SS. Petri et Pauli.

\section{8}

Łopaciński Jan Dominik biskup (Żmudź)

sakra 13 VI 1762 (niedziela) • Wilno ${ }^{93}$

CVIA, F 1135 ap 20, k. $175 r$

Dominica infra Octavam Corporis Christi, $2^{\text {a }}$ post Pentecosten, in cathedrali ecclesia [Vilnensi] consecratio Illustrissimi, Reverendissimi Domini Joannis Łopaciński, episcopi Samogitiae, ab Illustrissimo loci ordinario peracta [est], cui gratulatus est reverendus pater provincialis [Societatis Jesu].

92 Por. Polonica, s. 183, nr 128; Łętowski, Wspomnienia pamiętnikarskie, s. 227-229; S. J. Siennicki, Opis historyczny rzymsko-katolickiego kościoła Świętej Katarzyny w St. Petersburgu od r. 1783 do 1872, Warszawa 1872², s. XLIV. Zob. również Nitecki, kol. 263.

${ }^{93}$ Por. Wiadomości, s. 309 (tamże przyp. 67); Wołonczewski, Biskupstwo żmujdzkie, s. 102. Zob. także Szostkiewicz, s. 504; Dola (I), s. 281, nr 33 (data sakry 10 VI 1762); Nitecki, kol. 264. 
APBKr, S-Wi-4, s. 41

Dominica infra Octavam Corporis Christi [1762], festum S. Antonii. Hac die fuerat solemnis consecratio in ecclesia cathedrali [Vilnensi] Illustrissimi Domini Łopaciński in episcopum Samogitiae; consecravit Illustrissimus loci ordinarius Vilnensis cum Illustrissimis episcopis Żołkowski et Horain.

\section{9}

Łopaciński Józef Leon biskup (Żmudź)

sakra 30 VI 1776 (niedziela) $\bullet$ Warszawa $^{94}$

ADPt, AEp 71(128), s. 224-225 (Consecratio in episcopum Tripolitanum Illustrissimi et Reverendissimi Josephi Łopaciński, suffraganei Samogitiensis)

[Nos] Michael Georgius [Poniatowski, episcopus Plocensis] etc., universis [...] notum facimus [...], quod anno Domini millesimo septingentesimo septuagesimo sexto, die trigesima mensis Junii, quae fuit Dominica quinta post Pentecosten [...], Illustrissimo ac Reverendissimo Josepho Łopaciński, electo Tripolitano, suffraganeo Samogitiensi, munus consecrationis apud Sanctam Crucem Congregationis Missionis [Varsaviae] impendimus ac eundem Illustrissimum ac Reverendissimum Dominum Josephum Łopaciński [...], huic actui assistentibus Illustrissimis et Reverendissimis Dominis Joanne Aloisio Alexandrowicz, Helmensi, et Gaspare Cieciszewski, Kijoviensi, episcopi coadiutoribus [...], consecravimus.

Łubieński Kazimierz biskup (Kraków - Chełm/Krasnystaw - Kraków)
sakra 6 III 1701 (niedziela) • Jasna Góra [Częstochowa $]^{95}$

AKMK, LOrd 6, s. 154

Consecratio in episcopum Illustrissimi et Reverendissimi Domini, Domini Casimiri a Łubna Łubienski, Dei et Apostolicae Sedis gratia episcopi Heraclensis, suffraganei, canonici ac sede vacante episcopatus Cracoviensis ac Ducatus Severiensis administratoris, [facta est] in peraugusta Clari Montis Częstochoviensis basilica a Celsissimo ac Illustrissimo S.R.I. principe Georgio Albrachto Denhoff, comite, episcopo nominato Cracoviensi, duce Severiae, supremo Regni cancellario, tum et ab Illustrissimis et Reverendissimis Dominis Chrisostomo Gninski,

${ }^{94}$ Por. Wiadomości, s. 309; Polonica, s. 183, nr 130; Rękopism x. Bagińskiego, dominikanina prowincji litewskiej, (1747-1784 r.), wyd. E. Tyszkiewicz, Wilno 1854, s. 77. Zob. także Wołonczewski, Biskupstwo żmujdzkie, s. 105; Szostkiewicz, s. 504; Nitecki, kol. 264.

${ }^{95}$ Por. Przybyszewski, s. 115. Zob. także Szostkiewicz, s. 505; Nitecki, kol. 266; Polonica, s. $183-$ -184, nr 132. 
episcopo Camenecensi, et Stephano Mdzewski, episcopo Calamecensi, suffraganeo Gnesnesi, ad hunc actum assistentibus, ritu solenni, celebrata anno Domini millesimo septingentesimo primo, Dominica Laetare, quae fuit dies sexta Martii.

\title{
AJG, 535, s. $789-790$ (Consecratio suffraganei Cracoviensis in Claro Monte)
}

Annus Domini millesimus septingentesimus primus. Mense Martio, die $6^{\text {ta }}$ eiusdem, Dominica Laetare, nova Clari Monti nostro plurimis eiusmodi solennitatibus celeberrima accessit gloria ab actu solennissimo Illustrissimi et Reverendissimi Domini, Domini Casimiri a Łubna Łubienski, Dei et Apostolicae Sedis gratia [s. 790] episcopi Heracliensis, suffraganei, canonici, sede vacante episcopatus Cracoviensis et ducatus Severiae generalis administratoris, dum in Sacro Thaumaturgae Virginis Mariae Sacello a Celsissimo principe Illustrissimo et Reverendissimo Domino, Domino Albrachto Georgio Donhoff, nominato Cracoviensi, duce Severiae, supremo Regni cancellario, ritu solemni in episcopum consecraretur, inter festivas illustrissimorum Regni utriusque status procerum, nobilissimorum hospitum, praelatorum et plurimorum religiosorum comprecationes.

\section{1}

\section{Eubieński Stefan Wojciech biskup (Gniezno)}

sakra 27 II 1791 (niedziela) • Gniezno ${ }^{96}$

\author{
AAPzn, ASO 13, k. 31r
}

Anno 1791, Dominica Sexagesimae, quae fuit dies scilicet 27. mensis Februarii, [...] Illustrissimus [et] Reverendissimus episcopus [Franciscus Xaverius Rydzyński], suffraganeus Posnaniensis, in ecclesia metropolitana Gnesnensi, infra missarum solemnia pontificaliter celebratum, consecravit Illustrissimum [et] Reverendissimum Stephanum Łubieński, canonicum metropolitanum Gnesnensem, abbatem commendatarium Tremesnensem, [...] in episcopum Bibliensem, de suffraganeatu metropolitano Gnesnensi provisum, in assistentia conconsecratorum, qui fuerunt Illustrissimus [et] Reverendissimus Ludovicus de Mathy, episcopus Thanasiensis [...], et Michael Kosmowski, abbas claustralis Canonicorum Regularium Lateranensium Tremesnensis.

Madaliński Bonawentura biskup (Płock - Włocławek) sakra 27 XII 1672 (wtorek) • Warszawa ${ }^{97}$

\footnotetext{
${ }^{96}$ Por. Korytkowski, t. 2, s. 548, 643 przyp. 2. Zob. także Szostkiewicz, s. 506; Nitecki, kol. 268.

${ }^{97}$ Por. Korytkowski, t. 2, s. 577. Zob. także Szostkiewicz, s. 506; Dola (I), s. 285, nr 57; Nitecki, kol. 275.
} 
ADPt, AEp 42[69], s. 430-434 (Consecratio Illustrissimi et Reverendissimi Madalinski in episcopum Methonensem, coadiutorem Plocensem)

Scriptura super literis pergameneis in forma bullae apostolicae datis. Anno Incarnationis Dominica millesimo sexcentesimo septuagesimo secundo, mense Decembri, ipso die festi Sancti Joannis Apostoli et Evangelistae, in ecclesia collegiata Sancti Joannis Baptistae Varsaviensi praesens mandatum apostolicum seu munus consecrationis in episcopum commissum Illustrissimus et Reverendissimus in Christo Pater et Dominus, Dominus Joannes Gembicki [...], episcopus Plocensis, [...] intra missarum solemnia executus est; consecravit in episcopum Methonensem Reverendissimum in Christo Patrem Dominum, Dominum Bonaventuram Madalinski, assistentibus eidem Illustrissimis et Reverendissimis in Christo Patribus Dominis Posnaniensi et Chełmensi episcopis.

93

Marszewski Michał Jan biskup (Włocławek)

sakra 25 I 1857 (niedziela) $\cdot$ Warszawa ${ }^{98}$

ADWt, AKap 43(432), b.p. (Capitulum extraordinarium, feria $2^{\text {da }}$, die 16. Februarii 1857)

Dnia dwudziestego piątego stycznia roku bieżącego, który przypadł na niedzielę trzecią po Trzech Królach, w kościele metropolitalnym So Jana w Warszawie, J.W. J.X. Michał Marszewski, prałat scholastyk katedry włocławskiej, administrator diecezji kujawsko-kaliskiej, został poświęcony na biskupa tejże diecezji przez J.W. J.X Antoniego Melchiora Fijałkowskiego, arcybiskupa metropolitę warszawskiego, w asystencji J.W. J.X Jana Teraszkiewicza, biskupa bełzkiego, administratora diecezji chełmskiej obrządku grecko-unickiego, oraz J.W. J.X $\mathrm{X}^{\mathrm{a}}$ Tadeusza hr. Łubieńskiego, biskupa rodopolitańskiego, sufragana kaliskiego, w przytomności prałatów i kanoników czworga kapituł, to jest: warszawskiej, włocławskiej, kaliskiej i łowickiej, oraz wielu wysokich władz cywilnych wszelkiej rangi.

Massalski Ignacy Jakub biskup (Wilno) sakra 2 V 1762 (niedziela) $\cdot$ Wilno $^{99}$ CVIA, F 1135 ap 20, k. 168r-v

${ }^{98}$ Por. Polonica, s. 185, nr 143. Zob. również Dola (I), s. 300, nr 66 (odwrotna kolejność imion); Nitecki, kol. 283.

${ }^{99}$ Por. Wiadomości, s. 309 (tamże przyp. 70); Dola (I), s. 298, nr 28 (data sakry 27 VII 1762); Kasabuła, Ignacy Massalski, biskup wileński, s. 92-93. Zob. także Szostkiewicz, s. 512; Nitecki, kol. 285. 
[Die] 2. Maii 1762. Non fuit salutatio Tribunalis ob actum consecrationis in episcopatum Vilnensem Illustrissimi, Excellentissimi ac Reverendissimi [Jacobi] Ignatii ducis Massalski, qui actus in cathedrali ecclesia [Vilnensi] a hora $9^{\text {na }}$ usque ad $1^{\mathrm{mam}}$ a meridie duravit, inter continuo fere tormentorum bellicarum reboatus. Consecratorem egit Illustrissimus, Reverendissimus Dominus Horain, suffraganeus Samogitiensis et sede vacante administrator; assistentes Illustrissimi, Reverendissimi Domini Thomas Zienkowicz, administrator episcopatus Vilnensis, suffraganeus Albae Russiae, [et] Illustrissimus Antonius Żółkowski, suffraganeus Vilnensis, et Gabriel [k. 168v] Wodziński, episcopus Tebastensis, coadiutor Smolenscensis. Post gratulationem ab Illustrissimo consecratore dictam, et reverendo regente seminarii diaecesani, reverendus pater provincialis [Societatis Jesu] breviter neo-consecrato gratulatus est, deinde provincialis Patrum Franciscanorum Towiański, Patrum Piarum Scholarum, uterque ex charta legit, tum Pater Dominicanus e memoria. Panegyris nomine Academiae [Vilnensis] a reverendo patre provinciali [Societatis Jesu] oblata est ipso neo-consecrato, parenti eius illustrissimo campiduci, fratri eius illustrissimo mareschallo Tribunali Magni Ducatus Lithuaniae aliisque magnatibus, in reliquos sparsae sunt a scholasticis. Prandium inchoatum hora $12^{\mathrm{ma}}$, sed reverendus pater provincialis [Societatis Jesu] et multi alii patres ac scholastici nonnisi post horam $1 \frac{\mathrm{mam}}{\mathrm{m}}$ e cathedrali templo regressi pranderunt.

APBKr, S-Wi-4, s. 35. Por. LMAB, F9 162-166, k. 117 r (,,Aktu [...] konsekracyixięcia biskupa Massalskiego nie zapisano”)

Dominica $3^{\text {tia }}$ post Pascha [1762]. Hac die in ecclesia cathedrali [Vilnensi] consecratus est in episcopum Vilnensem Illustrissimus ac Reverendissimus Ignatius Massalski, cui Deus Ter Optimus Maximus benedicat in omnibus.

\section{5}

de Mathy Ignacy Stanisław biskup (Chełmża)

sakra 6 VI 1824 (niedziela) • Frombork ${ }^{100}$

AAWO, AB H 149, s. 2. Zob. również ADPelp, AKKCh, A 70, k. 11 (,,Dominica Pentecostes a. 1824 Frauenburgi consecratus”).

Anno 1824, die $6^{\text {ta }}$ Junii, Frauenburgi, in ecclesia archipresbyterali, [ego Andreas Stanislaus ab Hatten, episcopus Dianensis et suffraganeus Varmiensis], Illustrissimum Ignatium de Mathy in episcopum Culmensem consecravi, assistentibus Perillustribus, Reverendissimis Martino Fatschki, decano et vicario generali, et Josepho de Grąbczewski, canonico, Varmiensi.

${ }^{100}$ Zob. również Dola (I), s. 261, nr 52 (data sakry 7 VI 1824); Nitecki, kol. 286-287. 


\section{6}

de Mathy Ludwik Józef biskup ([Poznań])

sakra 7 V 1780 (niedziela) $・$ Warszawa $^{101}$

AAPzn, ASO 12, s. 1

Consecratio Illustrissimi Domini Ludovici Josephi de Mathy in episcopum Thanasiensem peracta est Varsaviae, in ecclesia monialium a Visitatione Beatae Mariae Virginis, anno Domini millesimo septingentesimo octuagesimo, die septima mensis Maii, quae erat Dominica infra Octavam Ascensionis Domini, multis praesentibus et assistentibus Regni Poloniae proceribus. Consecrator ipsius fuit Illustrissimus, Excellentissimus et Reverendissimus Dominus Antonius Onuphrius a Okęcie Okęcki, Dei et Apostolicae Sedis gratia episcopus Posnaniensis et Varsaviensis, supremus Regni cancellarius, Ordinum Aquilae Albae et Sancti Stanislai eques, conconsecratores vero fuerunt Illustrissimi et Reverendissimi Domini Joannes Aloysius Witold Alexandrowicz, episcopus Hełmensis, et Gasparus Columna Cieciszowski, episcopus Tebastensis, coadiutor Kiioviensis, officialis generalis Varsaviensis.

ASV, Archivio Concistoriale, Congregationis Concistorialis Acta, 1796-1799, k. 87r

Admodum Reverendus Pater Ludovicus Josephus de Mathy munus consecrationis in episcopum Thanasiensem anno Domini millesimo septingentesimo octuagesimo, die septima mensis Maii, quae erat Dominica infra Octavam Ascensionis Domini, Varsaviae, in ecclesia monialium a Visitatione Beatae Mariae Virginis suscepit et ab olim Illustrissimo et Reverendissimo Domino Antonio Onuphrio a Okęcie Okęcki, Dei et Apostolicae Sedis gratia episcopo Posnaniensi et Varsaviensi, supremo protunc regni cancellario, Ordinum Aquilae Albae et Sancti Stanislai equite, assistentibus conconsecratoribus Illustrissimis et Reverendissimis Dominis Joanne Aloysio Witold Alexandrowicz, episcopo Hełmensi, et Gasparo Kolumna Cieciszewski, episcopo Tabastensi, coadiutore Kiioviensi, officiali generali Varsaviensi, consecratum extitit.

97

Miaskowski Baltazar biskup (Włocławek) sakra 18 III 1618 (niedziela) $・$ Warszawa ${ }^{102}$

ADWt, 2-ABKP 18(37), k. 69v (Consecratio Reverendissimi Domini Balthasaris Miaskowski, confirmati suffraganei et canonici Vladislaviensis)

${ }^{101}$ Por. Wiadomości, s. 310-311 (tamże przyp. 71); Nowacki, t. 2, s. 191, nr 36. Zob. także Szostkiewicz, s. 512-513; Nitecki, kol. 287.

${ }^{102}$ Por. Chodyński, s. 49. Zob. także Szostkiewicz, s. 513; Nitecki, kol. 289. 
Die XVIII Martii [1618] Varszaviae. Illustrissimus et Reverendissimus Dominus, Dominus Paulus Volucki, Dei gratia episcopus Vladislaviensis et Pomeraniae, Reverendissimum Dominum Balthasarum Miaskowski, electum et confirmatum episcopum Margaritensem, suffraganeum et canonicum Vladislaviensem, iuxta ritum et praescriptionem Pontificalis Sacrae Romanae Ecclesiae, lecta prius Sanctissimi Domini nostri Pauli Papae V de super huiusmodi consecratio celebranda bulla, nec non praestito ab eodem recepto in talibus observari solitis corporali iuramento, assistentibus sibi Illustrissimis et Reverendissimis Dominis Stanislao Siecinski, Praemysliensi, et Adamo Nowodworsky, Camenecensi, episcopis, in ecclesia Fratrum Minorum Sancti Francisci de Observantia, publice in solemni missas sacrificio consecravit.

\section{8}

Miaskowski Zygmunt biskup (Chersonez/Kaffa) sakra 28 V 1645 (niedziela) • Poznańn 103

$A D W t, 3-A S W t P$ 4(97cz), k. 27r

Die 28. Maii [1645] in episcopum Erstonensem seu Cafensem consecratus est Perillustris et Reverendissimus Dominus Sigismundus Miaskowskij in ecclesia parochiali intra muros civitatis Posnaniensis ab Illustrissimo et Reverendissimo Domino, Domino Andrea de Szołdri Szołdrski, episcopo Posnaniensi, cui assistentiam in consecrando prebui [odnosi sie do sufragana włocławskiego Piotra Mieszkowskiego] cum Illustrissimo ac Reverendissimo Domino Joanne Baikowski, episcopo Enensi, suffraganeo Posnaniensi.

99

Mieszkowski Piotr biskup (Włocławek)

sakra 15 XI 1643 (niedziela) • Warszawa ${ }^{104}$

ADWt, 3-ASWtP 4(97cz), k. $20 r$

Anno Domini 1643, die vero 15. Novembris, Perillustris ac Reverendissimus Dominus Petrus Mieszkowsky, archidiaconus Warsaviensis, Sacrae Regiae Maiestatis secretarius, in episcopum Margaritensem consecratus [est] Warsaviae in ecclesia collegiata S. Joannis Baptistae ab Illustrissimo ac Reverendissimo Domino, Domino Andrea Szołdrski, episcopo Posnaniensi, sibi assistentibus Illustrissimo ac Reverendissimo Domino, Domino Alberto Krosnowski, Vendensi episcopo, ac

${ }^{103}$ Por. Chodyński, s. 55-56. Zob. także Szostkiewicz, s. 513.

${ }^{104}$ Por. Chodyński, s. 65. Zob. także Szostkiewicz, s. 515; Nitecki, kol. 292. 
Reverendo Domino, Domino Joanne Madalinski, suffraganeo Gnesnensi, abbate Landensi.

\section{0}

Mieszkowski Piotr Pawet biskup (Włocławek)
sakra 20 VIII 1679 (niedziela) $・$ Włocławek $^{105}$

ADWt, 3-ASWtP 6(97cz), k. 120r

Anno Domini millesimo sexcentesimo septuagesimo nono, die vero 20. Augusti, Perillustris et Reverendissimus Dominus Petrus Paulus de Mieszkowo Odrowąż Mieszkowski, custos Wladislaviensis, decanus Crusviciensis, Posnaniensis canonicus, Sacrae Regiae Maiestatis secretarius, in episcopum Marrochiensem consecratus [est] Vladislaviae in cathedrali ecclesia ab Illustrissimo et Reverendissimo Domino Stanislao Sarnowski, episcopo Vladislaviensi et Pomeraniae, sibi assistentibus Illustrissimo et Reverendissimo Stanislao in Lubraniec Dąmbski, episcopo Luceoriensi et Brestensi, ac Reverendissimo Domino Alberto Stawowski, episcopo Petrinensi [recte Petrensi], suffraganeo Gnesnensi, cancellario Vladislaviensi, Loviciensi canonico, Sacrae Regiae Maiestatis secretario.

\section{1}

Moszyński Konstantyn biskup (Inflanty/Wenden)

sakra 15 VIII 1733 (sobota) • Warszawa ${ }^{106}$

AJG, 915, s. 68 (zob. również tamże, s. 52: „,Die 2. Augusti 1733 dominus nominatus discedit Varsaviam pro consecratione et coronatione sua”; oraz s. 64: „Dominus nominatus denuntiat [...], quod pro coronatoribus sit assumpturus dominum nuntium, dominum episcopum Posnaniensem et Plocensem Załuski. Sed pro Posnaniensi egit suffraganeus Plocensis”)

Pater Moszinski Varsavia consecratus est die 15. Augusti [1733] in ecclesia nostra [tj. paulinów] ab Illustrissimo Domino Camillo Paulutio, nuntio apostolico, assistente Illustrissimo episcopo Plocensi et eius suffraganeo, in episcopum Livoniae, die 15. Augusti.

${ }^{105}$ Zob. Szostkiewicz, s. 515; Nitecki, kol. 292.

${ }^{106}$ Por. Wiadomości, s. 311-312 (tamże przyp. 75). Zob. także Szostkiewicz, s. 519; Dola (I), s. 266, nr 12; Nitecki, kol. 300. 


\title{
102
}

\author{
Naruszewicz Adam biskup (Smoleńsk - Łuck) \\ sakra 28 V 1775 (niedziela) $•$ Warszawa $^{107}$
}

ADPt, AEp 70(131), s. 260-261 (Consecratio in episcopum Emauzensem Illustrissimi et Reverendissimi Adami Naruszewicz, coadiutoris Smolenscensis)

[Nos] Michael Georgius [Poniatowski, episcopus Plocensis] etc., universis [...] notum facimus [...], quod anno Domini millesimo septingentesimo septuagesimo quinto, die vigesima octava mensis Maii, quae fuit Dominica sexta post Pascha [...], Illustrissimo ac Reverendissimo Adamo Naruszewicz, electo Emauzensi, coadiutore Smolenscensi, munus consecrationis in insigni ecclesia Sancti Joannis Baptistae collegiata Varsaviensi impendimus ac eundem Illustrissimum ac Reverendissimum Dominum Adamum Naruszewicz [...] inter missarum solemnia in episcopum Emauzensem [...], hic actui assistentibus Illustrissimis et Reverendissimis Dominis Stephano Gedroyc, Livoniae, et Gabriele Wodzinski, Smolenscensi, episcopis [...], in praesentia Serenissimi Stanislai Augusti, regis Poloniae [...], consecravimus.

\section{3}

Narzymski Antoni biskup (Ptock [Puttusk])

sakra 27 IX 1778 (niedziela) • Warszawa ${ }^{108}$

ADPt, AEp 73(104), s. 94-96 (Testimonium de consecratione in episcopum Evariensem Illustrissimi et Reverendissimi Antonii Narzymski, suffraganei Pultoviensis. Die 26. Septembris 1778, Varsaviae)

[Nos] Michael Georgius [Poniatowski, episcopus Plocensis] etc., universis [...] notum facimus [...], quod anno Domini millesimo septingentesimo septuagesimo octavo, die vigesima septima mensis Septembris, quae fuit Dominica decima sexta post Pentecosten, [...] Illustrissimo ac Reverendissimo Antonio Narzymski, neo nominato suffraganeo Pultoviensi, electo Evariensi, munus consecrationis in insigni ecclesia Sancti Joannis Baptistae collegiata Varsaviensi impendimus ac eundem Illutrissimum et Reverendissimum Dominum Antonium Narzymski [...] inter missarum solemnia in episcopum Evariensem [...], huic actui assistentibus Illustrissimis et Reverendissimis Dominis Christophoro Szembek, Uranopolitano

${ }^{107}$ Por. Wiadomości, s. 312 (tame przyp. 76); Polonica, s. 187, nr 153. Zob. także Długosz, Dzieje diecezji smoleńskiej, s. 79, nr 17; Szostkiewicz, s. 521; Dola (I), s. 293, nr 17; Nitecki, kol. 306-307; W. Zarzycki, Biskup Adam Naruszewicz - luminarz polskiego Oświecenia, Lublin 1999, s. $55-56$.

${ }^{108}$ Por. Wiadomości, s. 312; Korytkowski, t. 3, s. 91. Zob. także Szostkiewicz, s. 521; Nitecki, kol. 307; Polonica, s. 187, nr 154. 
et coadiutore Plocensi, ac Joanni Aloysio Alexandrowicz, Dardanensi et coadiutore Helmensi, episcopis, $[\ldots]$ consecravimus.

\section{4}

Nowiński Tomasz biskup ([Kraków])

sakra 27 X $1816\left(\right.$ niedziela) $・$ Miechów ${ }^{109}$

AKMK, LOrd 15, s. 4

Anno Domini 1816을 die 27. mensis Octobris, quae fuit Dominica XXI. post Pentecosten, quinta vero Octobris, expedita est consecratio in episcopum Illustrissimi et Reverendissimi Thomae Nowiński, Dei et Apostolicae Sedis gratia episcopi Bybliensis, Canonicorum Regularium Custodum S $\stackrel{\text { smi }}{ }$ Sepulchri praepositi generalis necnon praepositi infulati Miechoviensis, peractaque est solenniter in eadem ecclesia praepositurali Miechoviensi huius dioecesis Cracoviensis die qua supra, munus consecrationis conferente Illustrissimo, Excellentissimo ac Reverendissimo Domino Joanne Paulo Woronicz, episcopo Cracoviae, abbate commendatario Lendensi, [...] assistentibus Illustrissimo ac Reverendissimo Domino Francisco Xaverio Zglenicki, scholastico cathedrali nec non vicario in spiritualibus et officiali generali Cracoviensi, Peillustrique Reverendissimo Hippolyto Biberstein Starowieyski, canonico ecclesiarum cathedralium Cracoviensis et Kielcensis.

AKMK, LOrd 16, s. 1 (,, Consecratus ab Excellentissimo, Illustrissimo, Reverendissimo Domino Joanne Paulo Woronicz, episcopo Cracoviensi, die. 27. Octobris 1816 anno").

[Nos] Ioannes Paulus Pawęża Woronicz, Dei et Apostolicae Sedis gratia episcopus Cracoviensis, abbas commendatarius Lendensis, Ordinis Sí Stanislai primae classis eques, universis et singulis [...] notum facimus, quia inter missarum solemnia, in ecclesia Miechoviensi Canonicorum Regularium Custodum Sanctissimi Sepulchri Christi, anno Domini millesimo octingentesimo decimo sexto, die 27. mensis Octobris, [...] munus consecrationis episcopalis Illustrissimo ac Reverendissimo Domino Thoma Nowinski, praeposito generali Congregationis Custodum Sanctissimi Sepulchri, contulimus eumque in episcopum Bybliensem, iuxta ritum Sacrae Romanae Ecclesiae, ordinavimus, assistentibus, vigore indulti apostolici, duobus viris in dignitate ecclesiastica constitutis, nemque Perillustribus, Reverendissimis Francisco Xaverio Zglenicki, archidiacono ac vicario nostro in spiritualibus et officiali generali, tum Hippolito Biberstein Starowieyski, canonico, cathedralibus Cracoviensibus. [...] Miechoviae, die 27. Octrobris $1816^{\text {to }}$ anno.

${ }^{109}$ Por. Polonica, s. 187, nr 156. Zob. również Nitecki, kol. 312; Szczepaniak, Duchowieństwo diecezji krakowskiej w XVIII wieku, s. 654. 


\section{5}

Nowodworski Adam biskup (Kamieniec - Przemyśl - Poznań)
sakra 26 IV 1615 (niedziela) $・$ Rzym ${ }^{110}$

ASV, Miscellanea, Armadia XIII 33, k. 141v [140v]

Feria 6aㅡ, die 24. mensis Aprilis [1615], [...] Illustrissimus et Reverendissimus Dominus Adamus Nouodrurski [sic!], electus episcopus Camenecensis [...], praestitit solitum et debitum fidelitatis iuramentum in manibus Illustrissimi et Reverendissimi Domini, Domini Alexandri Peretti, Sancti Laurentii in Damaso S.R.E. diaconi cardinalis, de Montealto nuncupatis, praesentibus ibidem Admodum Reverendo Domino Stella Stella, canonico Sancti Laurentii in Damaso, et Domino Julio Vicomanno, Camerinensi, testibus etc.

Dominica, die 26. mensis Aprilis, [...] Illustrissimus et Reverendissimus in Christo Pater et Dominus, Dominus Benedictus, miseratione Divina episcopus Praenestensis, S.R.E. cardinalis, Iustinianus nuncupatus, vivae vocis oraculo, in ecclesia Sancti Eustachii consecravit in episcopum et pastorem Ecclesiae Camenecensis Admodum Illustrissimum et Reverendissimum Dominum Adamum Novodruurski [sic!], [...] assistentibus sibi Admodum Illustribus et Reverendissimis Dominis Amalteo Amalteo, archiepiscopo Atheniensi, et Ascanio Gesualdo, archiepiscopo Barensi, praesentibus ibidem Reverendissimis Dominis Paulo Aurelio de Exorgeis [Ecorgeis?], presbytero Ferdonensi[?], et Vigilio Gerardi, presbytero Lucanensi, testibus etc.

\section{6}

Oborski Mikołaj biskup (Kraków)

sakra 4 VIII 1658 (niedziela) • Warszawa ${ }^{I I I}$

AKMK, LOrd 4, k. 150r-v

Reverendissimus Nicolaus Oborski, Dei et Apostolicae Sedis gratia episcopus Laodicensis, suffraganeus, archidiaconus, in spiritualibus vicarius et officialis generalis Cracoviensis, anno Domini millesimo sexcentesimo quinquagesimo octavo, Dominica octava post Pentecostes, ipso festo Sancti Dominici Confessoris, quae fuit dies sexta [sic!] mensis Augusti, in ecclesia collegiata Sancti Joannis Baptistae Varsaviensi per Illustrissimos et Reverendissimos Dominos, Dominos Andream Trzebicki, Dei et Apostolicae Sedis gratia Cracoviensem, ducem Severiensem, Casimirum Florianum Czartoryski, ducem in Klewan, Vladislaviensem et Pomeraniae, Albertum Tholibowski, Posnaniensem, episcopos, in praesentia Suae Re-

${ }^{110}$ Por. Combaluzier, s. 177, nr 330. Zob. także Szostkiewicz, s. 523; Nowacki, t. 2, s. 105; Dola (I), s. 267, nr 28; Nitecki, kol. 312.

${ }^{111}$ Zob. Szostkiewicz, s. 523; Nitecki, kol. 315-316. 
giae Maiestatis, multorum senatorum ac procerum Poloniae, ad comitia Regni congregatorum, $[k .150 v]$ corona aetatis suae anno quadragesimo octavo, presbyteratus vigesimo secundo, in episcopum consecratus [est].

\section{7}

Odyniec Cyprian biskup (Mohylów [Połock]) sakra 4 IX [24 VIII st.st.] 1798 (wtorek) • Potock ${ }^{112}$

ASPF, Scritture riferite nei Congressi. Moscovia-Polonia-Ruteni, vol. 17, $k$. 551rv: „Iuramentum coram Illustrissimo, Reverendissimo Domino Joanne Benisławski, episcopo Gadarensi, coadiutore archiepiscopatus Mohiloviensis, [...] anno 1798, die 24. Augusti expletum”; tamże, $k$. 550r: ,,Iuramentum praestitum a Cypriano Odyniec, episcopo Hipponensi, in actu consecrationis suae peractae a Joanne Benislawski, episcopo Gadarensi, coadiutore Mohiloviensi"

Iuramentum hoc de verbo ad verbum ab Illustrissimo, Reverendissimo Domino Cypriano Odyniec, episcopo Hipponensi, suffraganeo Mohiloviensi, equite Ordinis Sancti Stanislai, tempore consecrationis suae in episcopum Hipponensem praestitum esse testor. Joannes Benisławski, episcopus Gadarensis, coadiutor archiepiscopatus Mohiloviensis, eques Ordinis Sancti Stanislai.

\section{8}

Olechowski Józef biskup (Kraków) $\quad$ sakra 16 VII $1786\left(\right.$ niedziela) $・$ Pultusk ${ }^{113}$

AKMK, LOrd 13, s. 5

Consecratio in episcopum [...] Illustrissimi et Reverendissimi Domini Josephi Olechowski, Dei et Apostolicae Sedis gratia episcopi Uranopolitani, suffraganei et archidiaconi cathedralis Cracoviensis, insignis collegiatae Sandomiriensis custodis, curiae episcopalis Cracoviensis auditoris et iudicis generalis etc., peracta est solemniter in insigni collegiata Pultoviensi, dioecesis Plocensis, die decima sexta mensis Julii, quae fuit Dominica sexta post Pentecosten, anno Domini millesimi septingentesimi octogesimi sexti, munus consecrationis conferente pastore loci, Celsissimo et Reverendissimo Domino Christophoro Hilario Szembek, episcopo Plocensi, duce Pultoviensi, Ordinum Aquilae Albae et Sancti Stanislai equite, assistentibus conconsecratoribus Illustrissimis et Reverendissimis Dominis Joanne Dembowski, episcopo Lambesitanensi, Vladislaviensi, Ordinis Sancti Stanislai equite, Adalberto Gadomski, episcopo Bendensi, Plocensi, et officiali gene-

${ }^{112}$ Zob. Nitecki, kol. 317.

${ }^{113}$ Por. Przybyszewski, s. 144. Zob. także Szostkiewicz, s. 524-525; Nitecki, kol. 319; Polonica, s. 187, nr 157; Szczepaniak, Duchowieństwo diecezji krakowskiej w XVIII wieku, s. 656. 
rali, Joanne Cantio Lenczowski, episcopo Abderitanensi, Lublinensi, et officiali generali, suffraganeis.

\section{9}

Olędzki Józef Kalasanty biskup (Kijów)

sakra 27 II 1763 (niedziela) - Warszawa ${ }^{114}$

Archiwum Państwowe w Lublinie, 110/6, nr 3, k. 15r

Anno 1763, die 27. mensis Februarii, quae indiget in Dominica $2^{\frac{\text { da }}{2}}$ Quadragesimae, Illustrissimus Olędzki, religionis nostrae [tj. pijarów] sacerdos, volente ac procurante Romae Celsissimo principe Czartoryski, palatino Russiae, obtenta terna dispensatione Romana, videlicet: permittente episcopum fieri, liberante a veste religiosa non retinenda, et indulgente bona haereditaria adire et possidere, in episcopum Cambisanopolitanum in partibus Asiae Minoris, Varsaviae, in nostra ecclesia [w kościele pijarów], fuit consecratus ab Illustrissimis Załuski, episcopo Kiioviensi (ut pote in eiusdem suffraganeum nominatus a Serenissimo rege Augusto $3^{\text {tio }}$ ), item Załuski, suffraganeo Plocensi, et Kierski, suffraganeo Posnaniensi.

110

Ossoliński Ignacy Franciszek Kandyd biskup (Baków - Kijów)

sakra 13 X 1765 (niedziela) • Warszawa ${ }^{115}$

AGAD, Dziat III, zespót 396; 247, k. 65r-v

Anno Domini 1765, die 13. Octobris, scilicet Dominica XX post Pentecosten alias $3^{\text {tia }}$ [sic!] Octobris, in ecclesia Patrum Franciscanorum Leopoli, ad aedes S. Crucis, [archiepiscopus Leopoliensis Venceslaus Hieronymus Sierakowski] solenni ritu consecravit Illustrrissimum et Reverendissimum Candidum Ossolinski, episcopum Dardanensem, coadiutorem episcopatus Baccoviensis, assistentibus Illustrissimo et Reverendissimo Jacobo Augustynowicz, ritus Armeni archiepiscopo Leopoliensi, et Illustrissimo et Reverendissimo Samuele Głowinski, episcopo Hebronensi, suffraganeo Leopoliensi, praesentibus Supremi Tribunalis [k. 65v] Regni iudicibus, ex illisque prioribus faces, panes et barilia vini ad offertorium ferentibus ac ministrantibus.

${ }^{114}$ Por. Wiadomości, s. 313. Zob. także Szostkiewicz, s. 525; Nitecki, kol. 320.

${ }^{115}$ Por. Kędzierski, Wiadomość o krzewieniu wiary świętej w Mołdawii y Wołoszczyznie, s. 15; Wiadomości, s. 313 (tamże przyp. 79). Zob. także Szostkiewicz, s. 528; Dola (I), s. 257, nr 18; Nitecki, kol. 324-325; Polonica, s. 187, nr 159. 


\section{1}

Ostaszewski Tomasz biskup (Płock)

sakra 12 XI 1815 (niedziela) • Warszawa ${ }^{116}$

ADPt, AEp 84(101), s. 313

Die 13. Novembris [1815]. Illustrissimus, Excellentissimus ac Reverendissimus Dominus, Dominus Thomas Ostaszewski, episcopus nominatus et administrator generalis sede vacante dioecesis Plocensis, Ordinis Sancti Stanislai eques, [...] die hesterna, nempe Dominica XXVI post Pentecosten, in ecclesia S. Crucis, intra missarum solemnia, per Illustrissimum ac Reverendissimum Dominum Adalbertum Gorski, episcopum Kielcensem, in episcopum Plocensem Varsaviae inauguratus est.

Ostrowski Daniel Eliasz biskup (Gniezno [Łowicz] - Warszawa [Łowicz]) sakra 30 VI 1816 (niedziela) $\cdot$ Warszawa ${ }^{117}$

Archiwum Kapituly Łowickiej, XII. A.1.14, s. 340 (Literarum de peracta consecratione tenor)

[Nos] Joannes Clemens Gołaszewski, Dei et Apostolicae Sedis gratia episcopus Vigrensis, abbas commendatarius Tremesnensis, senator Regni Poloniae, Sancti Stanislai $1 \frac{\text { mae }}{\frac{}{m}}$ classis eques, universis et singulis, praesentes literas visuris [et] lecturis, notum facimus et attestamur. Quia nos vigore literarum apostolicarum, primo Incarnationis Dominica, millesimo octingentesimo decimo sexto, die decima septima Aprilis, Romae datarum, ope Divina adiuti, munus consecrationis Illustrissimi, Excellentissimi, Reverendissimi Domini Danielis Eliae Korabita Ostrowski, electi episcopi Bethsaidensis, suffraganei Loviciensis, recepto prius ab eodem iuxta formam praescriptam in manibus nostris emisso solito fidelitatis iuramento, in ecclesia monialium de Visitatione Beatae Mariae semper Virginis, Varsaviae, Dominica quarta post Pentecosten, quae fuit dies trigesima mensis Junii, anni currentis 1816, servato per omnia ritu in Pontificali Romano praescripto, explevimus. Assistentibus huiusmodi consecrationis Illustrissimis, Excellentissimis, Reverendissimis Dominis Antonino Malinowski, episcopo Cynnensi, et Ignatio Koźmian, infulato praeposito Zamostensi, scholastico Lublinensi. Harum testimonio literarum, quibus manu nostra subscriptis, sigillum maius nostrum est impressum. Varsaviae, die 10. Octobris, anno Domini $1816^{\text {to }}$ signatum.

116 Por. „Gazeta Warszawska”, nr 89 z 7 XI 1815, s. 1795, nr 91 z 14 XI 1815, s. 1845. Zob. również Dola (I), s. 285, nr 68; Nitecki, kol. 325; Polonica, s. 187-188, nr 160.

${ }^{117}$ Por. „Gazeta Warszawska”, nr 53 z 2 VII 1816 - Dodatek, s. 1233. Zob. również Nitecki, kol. 326; Polonica, s. 188, nr 161. 


\section{3}

Paprocki Wacław biskup (Włocławek)

sakra 18 IX 1639 (niedziela) • Wolbórz ${ }^{118}$

ADWt, 3-ASWtP 3(97cz), k. 1r-v (dokument biskupa włoctawskiego Macieja Łubieńskiego)

Significamus praesentis litteris nostris, $[\ldots]$ quia nos $[\ldots]$ prius a Reverendissimo [k. $1 v]$ Domino Venceslao Paprocky, episcopo Margaritensi et suffraganeo nostro Vladislaviensi, recepto iuramento, eundem assistentibus nobis de more Ecclesiae Catholicae duobus episcopis, die decima octava mensis Septembris solenni ritu in ecclesia collegiata Volboriensi dioecesis Gnesnensis ex speciali facultate nobis hac in parte ab Illustrissimo et Reverendissimo Domino primate Regni concessa, in pontificem consecravimus.

\section{4}

Parczewski Piotr biskup (Smoleńsk)

sakra 7 IX $1636\left(\right.$ niedziela) $\bullet$ Rzym $^{119}$

ASV, Miscellanea, Armadia XIII 33, k. 193v [191v]

Sabbato die 6 ${ }^{\mathrm{a}}$ Septembris 1636 [...] Reverendus Dominus Petrus Parczewsky, electus Ecclesiae Smolenscensis, praestitit fidelitatis solitum iuramentum in manibus Serenissimi et Reverendissimi Domini Mauritii diaconi cardinalis de Sabaudia, praesentibus Illustrissimo Domino Ademaro de Sancto Georgio et Illustrissimo et Admodum Reverendo Domino Alessio Muratorio, presbytero dioecesis Salutiariensis, testibus etc.

Dominica 17a post Pentecosten, die 7a Septembris 1636, [...] Eminentissimus et Reverendissimus Dominus Joannes Baptista tituli S. Eusebii presbyter cardinalis Pamphilius, vigore mandati apostolici a Sanctissimo Domino Nostro Urbano Papae Octavo habiti, Romae, in ecclesia Beatae Mariae de Vallicella, assistentibus sibi Reverendissimis Dominis Octavio Broglia, episcopo Astensi, et Benedicto Lando, olim episcopo Forosemproniensi, consecravit Reverendissimum Dominum Petrum Parczewski, Polonum, in episcopum et pastorem Ecclesiae Smolenscensis, noviter erectae, praesentibus ibidem Illustrissimo Domino Lattantio Lattantio, Urbevetano, et Admodum Reverendo Bernardo Sfortia, presbytero Tudertino, testibus etc.

${ }^{118}$ Por. Chodyński, s. 51. Zob. także Szostkiewicz, s. 530; Nitecki, kol. 333.

119 Por. Długosz, Dzieje diecezji smoleńskiej, s. 29, 37, 76, nr 1; Combaluzier, s. 216, nr 584. Zob. także Szostkiewicz, s. 530-531; Dola (I), s. 293, nr 1; Nitecki, kol. 333-334. 


\section{5}

Pawłowski Józef biskup ([Poznań]) $\quad$ sakra 22 IX 1748 (niedziela) • Poznañ ${ }^{120}$

AAPzn, AC 214, k. 563r-v

[Anno Domini 1748], Solis XXII. Septembris. Hac die peracta est consecratio Illustrissimi et $[k$. 563r] Reverendissimi Domini Josephi comitis de Werbno Pawłowski, Dei et Apostolicae Sedis gratia episcopi Niochensis, in ecclesia cathedrali archidiaconi Psceviensis, vicarii in spiritualibus et officialis generalis Posnaniensis. Quem Celsissimus princeps, Reverendissimus Dominus Theodorus dux in Klewan et Zukow Czartoryski, Dei et Sanctae Sedis gratia episcopus Posnaniensis, in episcopum consecravit, assistentibus Illustrissimis et Reverendissimis Dominis Josepho Thaddaeo in Kiekrz Kierski, episcopo Bolinensi, suffraganeo, praeposito cathedrali Posnaniensi, [et] Francisco Kanigowski, episcopo Ramponensi [recte Toronensi], suffraganeo, praeposito Vladislaviensi, quae consecratio in frequentia hospitum in ecclesia cathedrali Posnaniensi celebrabatur.

\section{6}

Piechowski Michat biskup (Przemyśl)

sakra 10 VIII 1721 (niedziela) • Przemyśl $l^{121}$

AAPrzem, 69, k. 82r-v (Consecratio Reverendissimi Michaëlis Piechowski in episcopum Gratianopolitanum et creatio in officialem generalem Premisliensem). Zob. także AAWO, AK Ab 28, k. 49v (Copia listu od Jegomości Xiędza Czulskiego, suffragana chetmskiego, do Jegomości biskupa przemyskiego, 4. Julii A.D. 1721): „Że mnie Waszmość Dobrodziey rozkazem swoim pańskim disponis ad assistendum circa actum consecrationis Illustrissimi suffraganei Premysliensis, vere digni et emeriti in Ecclesia praelati, za osobliwy sobie poczytam honor, za co jak najunizeniey dziękuię"; oraz k. 50r-v (Copia listu Jegomości Xiędza biskupa chetmskiego do Jegomości Xiędza biskupa przemyskiego. Die 19. Julii A.D. 1721): „, Pisze do mnie Jegomość Xiadz Suffragan, ze iest in voto y oszwem [=owszem] desiderio za rozkazem Waszmości Pana y Dobrodzieia stuzyć na konsekracji Wielmożnemu Jegomości Xiędzu suffraganowi przemyskiemu; a zatym zjechawszy się w Jarostawiu, za pomoca Boska w sobotę, zaraz do Przemysla spieszyc nie zamieszkamy y na tym akcie assystować Wielce Milościwemu Waszmości Panu in festo Divi Laurentii"

Solis, decima mensis Augusti [1721], Premislia. Hac die Illustrissimus, Excellentissimus ac Reverendissimus Dominus, Dominus Christophorus Joannes in Słupow Szembek, episcopus Premisliensis, praepositus [k. 82v] generalis Miechoviensis, in ecclesia cathedrali Premisliensi, assistentibus sibi Illustrissimis ac Reverendissimis Dominis, Dominis Alexandro in Pleszowice Fredro, eadem gratia

${ }^{120}$ Por. Nowacki, t. 2, s. 190, nr 33. Zob. również Nitecki, kol. 338

${ }^{121}$ Por. Sarna, t. 2, s. 401. Zob. także Szostkiewicz, s. 534; Nitecki, kol. 342. 
Chełmensi, et Constantino Valentino Czulski, Claudianopolitano, episcopis, suffraganeo et officiali generali Chełmensi, Reverendissimum in Christo Patrem Michaelem in Piechowice Piechowski, nominatum suffraganeum Premisliensem, ritu solenni in episcopum Gratianopolitanum pontificaliter consecravit. [...] Qua die etiam eundem Reverendissimum Dominum consecratum in vicarium generalem in spiritualibus et officialem suum Illustrissima Celsitudo praefecit eique in praemissis plenam facultatem tribuit.

\section{7}

Pisztek (Pištěk) Franciszek arcybiskup (Praga - Tarnów - Lwów) sakra 14 XI 1823 (piątek) • Praga ${ }^{122}$

ASV, Archivio Consictoriale, Processus Consistorialis, vol. 232, k. 340 (dokument-poświadczenie dla biskupa F. Pisztka, wystawiony 24 XI 1831 przez arcybiskupa Alojzego Józefa Kolovrat-Krakovský'ego, metropolitę Pragi)

Quia nullum Tibi super accepta consecratione in episcopum ab antecessore nostro, tui consecratore, extraditum fuisse, publicum instrumentum nobis aperuisti, hisce simul ex actis ab antecessore relicitis, et propria manu scriptis, publicam fidem facimus, Te, praestitis de lege praestandis, die 14. Novembris anni 1823 ab antecessore nostro Wenceslao Leopoldo in ecclesia Virginum Beatae Ursulae hic [Pragae] existente, assistentibus Admodum Reverendo Domino Francisco Caroli, metropolitanae ecclesiae praeposito, et Admodum Reverendo Domino Carolo Fischer, metropolitanae ecclesiae decano, ambobus praelatis infulatis, in episcopum fuisse consecratum.

\section{8}

Pląskowski Fabian Franciszek biskup (Chetmża) sakra 9 VIII 1750 (niedziela) $・$ Warszawa ${ }^{I 23}$

ADPelp, C 54a [V 23], karta tytułowa: „Liber ordinatorum ab Illustrissimo et Reverendissimo Domino, Domino Fabiano Francisco Plaskowski, Dei et Apostolicae Sedis gratia episcopo Martyropolitano, suffraganeo Culmensi etc., consecrato die 9a mensis Augusti, quae erat Dominica 12. post Pentecostes Anno 1750

${ }^{122}$ Por. Polonica, s. 189, nr 170 (również, nr 171 i 172). Zob. także Kumor, Diecezja tarnowska, s. 260; Nitecki, kol. 351.

${ }^{123}$ Por. Wiadomości, s. 314 (tamże przyp. 81); Frydrychowicz, s. 26 (całość biogramu - s. 26-29, nr 8). Zob. także Szostkiewicz, s. 537; Nitecki, kol. 352. 


\title{
119
}

\author{
Poniatowski Michat Jerzy arcybiskup (Płock - Gniezno) \\ sakra 3 X 1773 (niedziela) • Warszawa ${ }^{124}$
}

ADPt, AEp 69[129], s. 37-39 (Consecratio in episcopum Celsissimi Michaelis principis Poniatowski)

[Nos] Joseph comes Garampi, [...] archiepiscopus Berytensis [...] et Sanctae Sedis Apostolicae in Regno Poloniae et Magno Ducatu Lithvaniae [...] nuntius, universis et singulis [...] notum facimus [...], quod anno Domini millesimo septingentesimo septuagesimo tertio ad praesens currente, die tertia mensis Octobris, [...] Illustrissimo et Reverendissimo Domino Michaëli ex principibus Poniatowski, Serenissimi Stanislai Augusti, regis Poloniarum, germani fratris, electo Plocensi episcopo, munus consecrationis in insigni ecclesia Sancti Joannis Baptistae collegiata Varsaviensi impendimus ac eundem Illustrissimum et Reverendissimum Dominum Michaëlem ex principibus Poniatowski, $[\ldots]$ inter missarum solemnia, in episcopum [...] consecravimus [...], et huic actui assistentibus Illustrissimis et Reverendissimis Dominis Felice Paulo Turski, Luceoriensi, et Antonio Onuphrio Okęcki, Helmensi, episcopis [...], in praesentia Serenissimi Stanislai Augusti, regis Poloniarum, tum illustrissimorum, excellentissimorum dominorum senatorum, ministrum, procerum, dignitariorum Regni et Magni Ducatus Lithvaniae ac nuntiorum ad comitia generalia Regni congregatorum.

\section{ASV, Fondo Garampi, 71, s. 865-867 (i dalszy opis na s. 867-870)}

Domenica 3. Ottobre. Feci [odnosi sie do autora zapiski, nuncjusza G. Garampiego] la consecrazione del Principe Abbate [Poniatowski] in vescovo di Plosco. Venne a prendermi monsignor gran cancelliere, vescovo di Posnania, e montai nella mia carozza di gala, in cui egli volle ch'io mi mettessi a mano diritta. In faccia stavami il suffraganeo di Plosco, e alla sua diritta un prelato di Plosco. Tanto io, che monsignor gran canceliere, eravamo in rochetto scoperto, cioè [s. 866] colla sola mozzetta. Monsignori canonici di Varsavia, e d'altre chiese, ch'erano venuti col vescovo di Posnania, andarono nelle carozze addietro. Arrivammo alla chiesa collegiata, dove trovammo tutto il capitulo di Varsavia alla porta con croce alzata. Monsignor vescovo prese dalla prima dignità l'aspersorio per darmelo. Io ne feci che intingere il dito e segnarmi. Tutta la funzione procede secondo l'ordine del Pontificale. Coro era pieno di cavallieri e dame dalla primaria nobiltà, e tutta la chiesa era pienissima di popolo. Quantunque la messe ne fosse che letta, ciò nonostante ebbi un prelato di Plosco per prete assistente [...]. Il re assiste a tutta la funzione nella tribuna superiore. Fui riaccompagnato alla porta della chiesa dal capitulo e rimontaì in carozza col solo suffraganeo sedente in faccia a me. [s. 867]

${ }^{124}$ Por. Wiadomości, s. 314 (tamże przyp. 83); Polonica, s. 190-191, nr 178 (również, nr 179-180). Zob. także Szostkiewicz, s. 538-539; Dola (I), s. 285, nr 65; Nitecki, kol. 355-356; Przybyszewski, s. 165-167. 
Diedi pranzo ai 10 vescovi esistenti, 6 parenti del consecrato, ai ministri di stato, che furono, e ad altri in numero 30 , che avevano necessaria relazione, $o$ al consecrato o al re, che dovea intervenirvi.

\section{0}

Poniński Karol biskup (Poznań)

sakra 24 II 1726 (niedziela) $・$ Warszawa ${ }^{125}$

AAPzn, ASO 7, k. $56 r$

Anno Domini millesimo septingentesimo vigesimo sexto, mense Februario, die vigesima quarta, ipsa tunc Dominica Sexagesima existenti, Varsaviae, in insigni collegiata Sancti Joannis Baptistae, Illustrissimus, Excellentissimus et Reverendissimus Dominus Joannes Joachimus de Czekarzewice et Tenczyn Tarło, episcopus Posnaniensis, consecravit in episcopum Aradensem Illustrissimum Carolum Łodzia Poninski, suffraganeum suum Posnaniensem, ecclesiarum cathedralis Posnaniensis et Vschoviensis praepositum. Conconsecratores fuerunt: primus Illustrissimus et Reverendissimus Andreas Stanislaus Kostka Załuski, episcopus Plocensis, secundus Illustrissimus Dominus Stanislaus Hosius, episcopus Camenecensis, abbas Czervenensis.

$$
\text { AAPzn, ASO 8, k. [17v] }
$$

[Dies] 24. Februarii [1726], Varsaviae, Dominica Sexagesimae, Illustrissimus [Dominus Stanislaus Josephus Hosius, episcopus Camenecensis], fuit assistens consecrationi Illustrissimi Poninski, episcopi Metropolitanensi [sic!]. Primus consecrator [erat] Illustrissimus episcopus Tarło, Posnaniensis; [secundus assistens] Illustrissimus Załuski, episcopus Plocensis; in ecclesia insignis collegiatae S. Joannis Baptistae.

\section{1}

Prażmowski Adam Michat biskup (Płock)

sakra 7 VI 1818 (niedziela) $\bullet$ Ptock $^{126}$

ADPt, AEp 85(93), s. 80. Zob. także ASV, Archivi delle Rappresentanze Pontificie, Vienna, vol. 240, k. 221r-222v (list biskupa A.M. Prażmowskiego do nuncjusza wiedeńskiego A.G. Severoliego z daty: Puttusk, 7 VII 1818, z informacją o wykonanym podczas aktu święceń biskupich iuramentum fidelitatis: „Avendo compiuta l'atto della mia consecrazione nella cathedrale di Plocko e prestito il giuramento prescritto dalle bolle, ho l'onore transmetterlo a Vostra Eccellenza")

${ }^{125}$ Por. Nowacki, t. 2, s. 189, nr 28. Zob. także Szostkiewicz, s. 539; Nitecki, kol. 356.

${ }^{126}$ Por. Polonica, s. 192, nr 186. Zob. również Dola (I), s. 285, nr 70; Nitecki, kol. 359. 
Die Solis 7 dissimus Dominus Adam Michael de Prażmow Prażmowski, Plociae, in ecclesia cathedrali [...], per Illustrissimum Franciscum Malczewski, episcopum Cuiaviensem, assistentibus Illustrissimis Antonio Luboradzki, episcopo Thanasiensi, suffraganeo et praeposito cathedrali ac collegiatae Pultoviensis, tum Felice Lewiński, episcopo Eretriensi, suffraganeo et decano cathedrali Vladislaviensi ac scholastico archicollegiatae Lanciciensis, Ordinis S. Stanislai equite, intra missarum solemnia, praesente frequentissimo populi concursu, in episcopum Plocensem feliciter inauguratus est.

\section{2}

Pruski Andrzej biskup (Przemyśl)

sakra 7 VIII 1729 (niedziela) • Warszawa ${ }^{127}$

AAPrzem, 145, karta tytulowa:,,Acta officii episcopalis Reverendissimi in Christo Patris et Domini, Domini Andrea in Prusy Pruski, Dei et Apostolicae Sedis gratia episcopi Tanensis, suffraganei, archidiaconi cathedralis, vicarii in spiritualibus, officialis generalis Premisliensis, Denoviensis et Radymnensis praepositi, post solennem sui in episcopum consecrationem ab Excellentissimo, Illustrissimo et Reverendissimo Domino, Domino Camillo Paulutio, sacrosanctae Lateranensis ecclesiae canonico, utriusque Signaturae referendario, Dei et Apostolicae Sedis gratia archiepiscopo Iconiensi, Sanctissimi Domini nostri et Domini Benedicti, Divina providentia Papae eius nominis XIII. praelato domestico et assistente, et S. Sedis Apostolicae in Regno Poloniae et Magno Ducatu Lithvaniae cum facultatis legati de latere nuntio apostolico, assistentibus sibi Illustrissimis, Excellentissimis et Reverendissimis Dominis, Dominis Joachimo Tarlo, Posnaniensi, et Stanislao Hosio, Camenecensi, eadem gratia episcopis, ad praesentiam plurimorum Regni procerum, Varsaviae, in ecclesia Reverendorum Patrum Theatinorum, die decima septima mensis Julii, anno Domini millesimo septingentesimo vigesimo nono peractam".

AAPzn, ASO 7, k. 57r-v

Anno Domini 1729, mense Augusto, die 7를 , quae erat Dominica nona post Pentecosten, Varsaviae, in ecclesia Patrum Theatinorum, consecranti Excellentissimo, Illustrissimo et Reverendissimo Domino Camillo Pauluccio, archiepiscopo Iconiensi, per Regnum Poloniae nuntio apostolico, Illustrissimum et Reverendissimum Josephum [sic!] Pruski in episcopum Tanensem, [pozostawiono puste miejsce], tanquam conconsecrator adstitit Illustrissimus, Excellentissimus et Reverendissimus Dominus Joannes Joachimus comes de Tęczyn et Czekarzewice Tarło, episcopus $[k .57 v]$ Posnaniensis, una cum Illustrissimo, Excellentissimo et Reve-

${ }^{127}$ Por. Polonica, s. 192, nr 188. Zob. także Szostkiewicz, s. 542; Nitecki, kol. 362; Wiadomości, s. 315 (tamże przyp. 87). 
rendissimo Domino [pozostawiono puste miejsce] Hosio, episcopo Camenecensi, abbate commendatario Czerminense [sic!].

\section{3}

Raczyński Antoni biskup ([Gniezno])

sakra 20 VIII 1809 (niedziela) $\cdot$ Ladd $^{128}$

AAGn, ACons D 7, s. 287-288 (Testimonium consecrationis Illustrissimi Raczyński, abbatis Landensis)

[Nos] Ignatius comes Nałęcz de Małoszyn et Raczyno Raczyński, princeps archiepiscopus Gnesnensis etc., [...] notum facimus et attestamur, quia nos [...] munus consecrationis Illustrissimi, Reverendissimi Antonii Raczyński, electi episcopi Hetaloniensis, abbati Ordinis Cisterciensis monasterii Landensis et per Ducatum Varsaviensem commisarii, vicarii et visitatoris generalis, recepto prius ab eodem [...] fidelitatis iuramento, in ecclesia praedicti monasterii Landensis die hesterno, nempe Dominica decima tertia post Pentecosten, quae fuit dies vigesima mensis Augusti anno currenti millesimo octingentesimo nono, $[\ldots]$ explevimus, Illustrissimo, Reverendissimo Ignatio Bardziński, eadem gratia episcopo Satalensi, suffraganeo, canonico, vicario in spiritualibus et officiali nostro generali Gnesnensi, et loco alterius episcopi, vi facultatis apostolicae [...], Perillustri, Reverendissimo Adalberto Lipski, praeposito infulato collegiatae ecclesiae Chocensis, consecrationi huiusmodi assistentibus. [...] Ciążeni, die 21 ${ }^{\mathrm{ma}}$ Augusti anno Domini 1809.

\section{4}

Raczyński Ignacy arcybiskup (Poznań - Gniezno)
sakra 9 XI 1794 (niedziela) $\cdot$ Wschowa ${ }^{129}$

AAPzn, ASO 13, k. 34v-35r

Anno Domini 1794, die 9 ${ }^{\text {na }}$ mensis Novembris, quae fuit Dominica III. Novembris, post Pentecosten vero Dominica XXII, Illustrissimus [et] Reverendissimus Xaverius comes de Werbno Rydzynski, episcopus Nicopolitanus, suffraganeus et archidiaconus Posnaniensis, custos metropolitanus Gnesnensis, Ordinis Sancti Stanislai atque Aquilae Rubrae eques, consecravit in ecclesia parochiali Wschoviensi, infra missarum solemnia, pontificaliter celebratarum, Illustrissimum, Excellentissimum [et] Reverendissimum Dominum Ignacium comitem in Małoszyn et Raczyno Raczynski, scholasticum cathedralem Posnaniensem, equitem Aquilae

${ }^{128}$ Zob. Nitecki, kol. 371.

${ }^{129}$ Por. Polonica, s. 192-193, nr 192 (także, nr 193); Nowacki, t. 2, s. 114. Zob. również Dola (I), s. 289, nr 74; Nitecki, kol. 372. 
Rubrae, in episcopum dioecesanum Posnaniensem, in assistentia duorum conconsecratorum, qui fuerunt Illustrissimus [et] Reverendissimus Dominus Ludovicus de Mathy, episcopus Thanasiensis, canonicus metropolitanus Gnesnensis et cathedralis Posnaniensis, Ordinis Sancti Stanislai eques, et Reverendissimus Szołdrski, abbas claustralis Premetensis.

AAPzn, ASO 12, s. 104-105. Zob. również tamże, CP 64, k. 11v (Delegatio ad actum consecrationis episcopi): „Illustrissimi, Perillustres, Reverendissimi domini capitulum ad assistendum actui consecrationis Illustrissimi, Excellentissimi et Reverendissimis Domini Ignatii comitis Raczyński in episcopum Posnaniensem in civitate Wschowa die $9^{n a}$ mensis et anni currentis peragendae, Reverendissimos Dominos Josephum Rokossowski, archidiaconum Sremensem, et Fabianum Maczyński, canonicum, cathedralis Posnanienses, [delegarunt]"

Annus Dominis 1794. Die $9^{\text {na }}$ mensis Novembris, quae fuit Dominica XXII. post Pentecosten, incidente Dominica III. Novembris, videlicet ipso festo patrocini Beatissimae Mariae Virginis in ecclesia parochiali Wschoviensi, dioecesis Posnaniensis, fuit Illustrissimus Dominus [Ludovicus Josephus de Mathy, episcopus Thanasiensis], conconsecrator, in assistentia Reverendissimi Domini Joannis Szołdrski, Ordinis Cisterciensis abbatis claustralis Premetensis, ex speciali dispensatione apostolica, ad consecrationem Illustrissimi, Excellentissimi ac Reverendissimi Domini Ignatii Nałęcz comitis de Małoszyn et Raczyno Raczynski [...] in episcopum Posnaniensem, quam consecrationem perfecit Illustrissimus Franciscus Xaverius de Werbno Rydzyński, episcopus Nicopolitanus, suffraganeus Posnaniensis.

\section{5}

Radoszewski Wojciech Józef biskup (Kraków [Sandomierz])
sakra 26 VIII 1787 (niedziela) $・$ Sandomierz ${ }^{130}$

AKMK, LOrd 13, s. 13

Anno 1787, die vero 26. Augusti, quae fuit Dominica 13. post Pentecosten, quinta vero Augusti, expedita est consecratio in episcopum Illustrissimi et Reverendissimi Adalberti Boxa Radoszewski, Dei et Apostolicae Sedis gratia episcopi Hirinensis, suffraganei et canonici Sandomiriensis, praepositi infulati Klimontoviensis. Peracta est solemniter in insigni collegiata Sandomiriensi, huius dioecesis Cracoviensis, die qua supra 26. Augusti, quae fuit Dominica 13. post Pentecosten, quinta vero Augusti, munus consecrationis conferente eodem Illustrissimo et Reverendissimo Domino Josepho Olechowski, Dei et Apostolicae Sedis gratia episcopo Uranopolitano, sufraganeo, archidiacono cathedrali, curiae episcopalis Cra-

${ }^{130}$ Por. Przybyszewski, s. 267. Zob. również Nitecki, kol. 373; Szczepaniak, Duchowieństwo diecezji krakowskiej w XVIII wieku, s. 675-676. 
coviensis auditore et iudice generali, Ordinis S. Stanislai equite, assistentibus conconsecratoribus Illustrissimis et Reverendissimis Dominis Melchiore Kochnowski, episcopo Dionisiensi, archidiacono cathedrali et officiali generali Hełmensi, ad Tribunal Regni iudice deputato, Ordinis S. Stanislai equite, et Joanne Cantio Lenczowski, episcopo Abderitanensi et officiali generali Lublinensi, suffraganeis.

\section{Archiwum Kapituly Katedralnej w Sandomierzu, 127, s. 2-3}

Anno Domini millesimo septingentesimo octogesimo septimo, die vigesima sexta mensis Augusti, quae fuit dies Dominica decima tertia post Pentecosten, in ecclesia insigni collegiata et parochiali Sandomiriensi, ab Illustrissimo et Reverendissimo Domino, Domino Dei et Apostolicae Sedis gratia episcopo Uranopolitano, suffraganeo, archidiacono, auditore curiae episcopalis et iudice generali Cracoviensi Josepho Olechowski, in assistentia Illustrissimorum et Reverendissimorum Dominorum Joannis Cantii Lenczowski, Abderitanensis episcopi, Lublinensis suffraganei, et Melchioris Kochnowski, episcopi Dionysiae, suffraganei Chełmensis, in praesentia plurimorum de ordine senatorio, equestri, nobilium, utriusque sexus, tum copiosissimae et numerosissimae plebis (quam amplus ambitus ecclesiae insignis collegiatae Sandomiriensis capere non poterat) varii status et conditionis, Illustrissimus et Reverendissimus Dominus, Dominus Adalbertus Josephus Boxa Radoszewski, in episcopum Hirinensem, suffraganeum primum Sandomiriensem, consecratus, statim cum facultate Celsissimi et Reverendissimi Domini, Domini Michaelis principis Poniatowski, [s. 3] archiepiscopi Gneznensis, legati nati Regni Poloniae et Magni Ducatus Lithvaniae primatis primique principis, administratoris episcopatus Cracoviensis cum plena iurisdictione, in Vinea Domini operari caepit.

\section{6}

Radziejowski Michat Stefan arcybiskup (Warmia - Gniezno), kardynat
sakra 26 I 1681 (niedziela) $\bullet W^{2}$ Warszawa ${ }^{131}$

AAWO, AB A 16, k. 20r-v (Consecratio Illustrissimi ac Reverendissimi Domini, Domini Michaelis comitis in Radzieiowice et Kryłow Radziejowski in episcopum Varmiensem et Sambiensem)

Die Dominica, quae erat XXVI mensis Januarii, anno Domini millesimo sexcentesimo octuagesimo primo, Varsaviae, Illustrissimus ac Reverendissimus Dominus, Dominus Michael Stephanus comes in Radziejowice et Kryłow Radziejowski, acceptis Roma bullis pro episcopatu Varmiensi, occupato pridie post praesti-

${ }^{131}$ Por. Polonica, s. 193, nr 194; R. Kawecki, Kardynat Michat Stefan Radziejowski (1645-1705), Opole 2005, s. 29. Zob. także Szostkiewicz, s. 544; Dola (I), s. 295, nr 32; Nitecki, kol. 373-374. 
tum senatorium iuramentum in Senatu loco, ac gratis Sacrae Regiae Maiestatis, votoque senatorio in comitiis $[k .20 v]$ quae sub hoc tempus celebrate sunt, ad plausum placitumque omnium habito, die ut supra hodierna ex residentia sua numeroso antecendentis equitatus stipatus comitatu profectus est rheda sua ad ecclesiam collegiatam Sancti Joannis Baptistae ibique ab Illustrissimo ac Reverendissimo Joanne Małachowski, episcopo Cracoviensi, assistentibus duobus ad hunc actum episcopis, videlicet Illustrissimo Stanislao Swięcicki, Chełmensi, [et] Stanislao Witwicki, Kiioviensi, iuxta praescriptum in Pontificali normam consecratus est in episcopum Varmiensem et Sambiensem, in praesentia Serenissimi regis, reginae totiusque Domus regiae, magnoque concursu senatorum, magnatum, nobilitatis populique pro comitiis tunc inchoatis congregatorum.

\section{7}

Rudziński Stefan Atanazy biskup (Baków)

sakra 13 VIII $1662\left(\right.$ niedziela) $\bullet$ Rzym ${ }^{132}$

ASV, Miscellanea, Armadia XIII 33, k. 2374 [235r]

Die 13. Augustii [1662], Dominica XI. post Pentecosten, Eminentissimus Dominus Marcellus Santacrucius, episcopus Tiburtinus, vigore mandati apostolici consecravit in ecclesia Sancti Stanislai Polonorum Illustrissimum Dominum Fratrem Stephanum Athanasium Rugienschi [sic!], Ordinis Sancti Francisci de Observantia, in episcopum et pastorem Ecclesiae Baccoviensis in Vallachia, assistentibus sibi Illustrissimis Dominis Fratre Francisco Soimirovich, eius Ordinis, archiepiscopo Ochridano, et Fratre Josepho Chiante, Ordinis Praedicatorum, episcopo olim Morsicano, praesentibus vero Dominis Marcantonio et Julio, fratribus de Vascles[?], Romanis, eiusdem cardinalis familiaribus, testibus etc.

\section{8}

Rupniewski Stefan Bogusław biskup (Lwów - Kamieniec - Łuck) sakra 9 VII 1713 (niedziela) $・$ Kraków ${ }^{133}$

AKMK, LOrd 7, s. 128

Celsissimus princeps Illustrissimus et Reverendissimus Dominus, Dominus Casimirus a Łubna Łubienski, episcopus Cracoviensis, dux Severiensis, anno Domini 1713, Dominica $5^{\text {ta }}$ post Pentecostes, quae fuit 9. Julii, in ecclesia archipresbyte-

${ }^{132}$ Por. Combaluzier, s. 243, nr 754 (forma nazwiska Rudzicki). Zob. także Szostkiewicz, s. 549; Dola (I), s. 257, nr 8; Nitecki, kol. 385 (forma nazwiska Rudnicki).

${ }^{133}$ Por. Przybyszewski, s. 183; Polonica, s. 193, nr 197. Zob. także Szostkiewicz, s. 549; Nitecki, kol. 386-387; Krętosz, Organizacja archidiecezji lwowskiej, s. 103, nr 8; Wiadomości, s. 317. 
rali Beatae Mariae Virginis in Circulo Cracoviensi, infra missarum solennia, consecravit Perillustrem et Reverendissimum Dominum Stephanum a Rupniew Rupniewski, canonicum Cracoviensem, in episcopum Licopoliensem et suffraganeum Leopoliensem, assistentibus Illustrissimis et Reverendissimis Dominis Michaele in Słupow Szembek, episcopo Paphensi, suffraganeo et decano Cracoviensi, et Joanne Lubieniecki, episcopo Bacchoviensi, in frequentia Illustrissimorum procerum Regni et aliorum multorum hospitum concursu.

\section{9}

Rydzyński Franciszek Ksawery biskup (Poznań - Chełmża)
sakra 14 I 1781 (niedziela) $・$ Warszawa $^{134}$

AAPzn, ASO 13, k. [2r]

Illustrissimus ac Reverendissimus Dominus Rydzyński praesentatus [est] ad suffraganeatum Posnaniensem per olim Illustrissimum ac Reverendissimum Andream Stanislaum Kostka Młodziejowski, episcopum Posnaniensem, [...] [et] consecratus per Illustrissimum ac Reverendissimum Antonium Okęcki, episcopum Posnaniensem, cancellarium Regni, in assistentia duorum episcoporum, nempe Illustrissimi ac Reverendissimi Antoni Sierakowski, episcopi Livoniae, tum Illustrissimi ac Reverendissimi Christophori Szembek, coadiutoris episcopi Plocensis, idque Varsaviae, in ecclesia monialium de Visitatione, anno $1781^{\underline{\mathrm{mo}}}$, die $14^{\text {ta }}$ mensis Januarii.

\section{0}

Sapieha Józef Julian biskup (Wilno)

sakra 1 IX 1737 (niedziela) $・$ Wilno ${ }^{135}$

BN, BOZ 941, s. 254 (tamże, s. 253: „21. Augusti [1737] Illustrissimus episcopus Vilnensis [...] venit Vilnam ut me consecraret [...]. 31. Augusti venit [etiam] episcopus Samogitiensis cum suo suffraganeo. Episcopus vero Smolenscensis cum ratione antiquitatis consecrationis vellet praecedere Samogitiensem, illo reluctante excusavit se ne conconsecrator esset, ei substitutus est suffraganeus Samogitiae, quem hoc praevidens Vilnam evocaveram")

Dominica 12. post Pentecostes, prima et insimul die 1 1 ma Septembris [1737], consecrationi meae destinata [autorem zapiski biskup J.J. Sapieha]. Summo mane episcopus [Vilnensis] sua tormenta in signum explodere iussit, dein castellanus

${ }^{134}$ Por. Wiadomości, s. 317 (tamże przyp. 96); Polonica, s. 193, nr 198; Nowacki, t. 2, s. 190, nr 35. Zob. również Korytkowski, t. 3, s. 434; Nitecki, kol. 389.

${ }^{135}$ Por. Wiadomości, s. 318 (tamże przyp. 98); J. Kurczewski, Kościót zamkowy czyli katedra wileńskiej w jej dziejowym, liturgicznym, architektonicznym i ekonomicznym rozwoju, t. 3, Wilno 1916, s. 313. Zob. także Szostkiewicz, s. 551; Nitecki, kol. 393. 
Trocensis, referendarius Monstowicz, praefectus armamentarii, [...] cum rhedis et apparatu splendido in domum meam venerunt et me ad templum cathedralem deduxerunt in magno comitatu, ubi me iam Vilnensis, Samogitiensis, Smolenscensis episcopi [et] suffraganeus Samogitiensis praestolabuntur. Omnes me sic praecedentes ad episcopum adduxerunt, quo salutato inde ad capellam Nominis Mariae, unde sacro ritu deductus sum ad altare maius et consecrante episcopo Vilnensi et Samogitiensi cum suo suffraganeo consecratus sum assistente toto capitulo.

\section{1}

Siemieński Marcin biskup (Gniezno) ～sakra 15 IX 1816 (niedziela) • Ciążeń136

AAGn, ACons D 9, s. 46-47 (Testimonium consecrationis Illustrissimi, Reverendissimi Martini Siemieński)

[Nos] Ignatius comes Nałęcz de Małoszyn et Raczyno Raczyński, princeps archiepiscopus Gnesnensis etc., [...] notum facimus et attestamur, quia nos [...] munus consecrationis Illustrissimi, Reverendissimi Martini Siemieński, electi episcopi Cyrenensis, custodis metropolitani, vicarii in spiritualibus et officialis nostri generalis Gnesnensis, recepto prius ab eodem [...] fidelitatis iuramento, in ecclesia parochiali Ciążenensi, de nostra provincia Gnesnensi existente, die festive Nominis Beatissimae Virginis Mariae, incidente in Dominicam decimam quintam post Pentecosten, quae fuit decimaquinta mensis Septembris anni currentis millesimi octingentesimi decimi sexti, [...] explevimus, Perillustribus, Reverendissimis Eduardo Markowski, Sancti Augustini Canonicorum Regularium monasterii Tremesnensis abbate claustrali, Adalberto Lipski, praeposito infulato Chocensi, canonico cathedrali Chełmensi, loco episcoporum, vi facultatis apostolicae $[\ldots]$ huiusmodi consecrationi assistentibus.

\section{AAGn, ACons G II 5, k. [3r]}

Illustrissimus, Reverendissimus Dominus Martinus Siemieński, custos ecclesiae metropolitanae, vicarius in spiritualibus et officialis generalis Gnesnensis, vigore mandati apostolici de datum: Romae, anno [...] 1815, octavo Idus Martii, consecratus [est] in episcopum Cyrenensem a Celsissimo, Reverendissimo Domino Ignatio Raczyński, archiepiscopo Gnesnensi, Dominica XV. post Pentecosten, quae fuit dies 15a mensis Septembris anno Domini 1816, in ecclesia parochiali Ciążenii.

${ }^{136}$ Zob. Nitecki, kol. 400; Szczepaniak, Duchowieństwo diecezji krakowskiej w XVIII wieku, s. 685 . 


\section{2}

Sierakowski Michat Roman biskup (Przemyśl - [Latyczów]) sakra 8 XII 1778 (wtorek) $\cdot$ Warszawa ${ }^{137}$

ADPt, AEp 73(104), s. 108-109 (Testimonium de consecratione in episcopum Prusensem Illustrissimi et Reverendissimi Domini Michaelis Sierakowski, suffraganei Premysliensis)

[Nos] Michael Georgius, [episcopus Plocensis] etc., universis [...] notum facimus [...], quod anno Domini millesimo septingentesimo septuagesimo octavo, die octava mensis Decembris, quae fuit festum Immaculatae Conceptionis Beatae Mariae Virginis, [...] Illustrissimo ac Reverendissimo Michaeli Sierakowski, nominato suffraganeo Premysliensi, electo Prusensi, munus consecrationis in insigni ecclesia Sancti Joannis Baptistae collegiata Varsaviensi impendimus ac eundem Illustrissimum et Reverendissimum Dominum Michaelem Sierakowski [...] inter missarum solemnia in episcopum Prusensem [...], huic actui assistentibus Illustrissimis et Reverendissimis Dominis Stephano Giedroyc, Samogitiae, et Gasparo Cieciszowski, coadiutore Kijoviae, episcopis, [...] consecravimus.

\section{3}

Sierakowski Wacław Hieronim biskup (Inflanty/Wenden - Kamieniec - Przemyśl - Lwów)

sakra 4 V 1738 (niedziela) $\cdot$ Kielce $e^{138}$

AKapMK, LA 36, s. 27

Anno Domini 1738, die 4. Maii, Kielciis, in ecclesia collegiata Kielcensi, Eminentissimus et Reverendissimus Dominus cardinalis Lipski, episcopus Cracoviensis, dux Severiae, consecravit uno die duos, scilicet Illustrissimum et Reverendissimum Dominum Sierakowski, episcopum [pozostawiono miejsce na wpisanie nazwy stolicy tytularnej], coadiutorem Livoniae, et Illustrissimum et Reverendissimum Dominum Jezierski, episcopum Valachiae seu Bacoviensem.

AGAD, Dziat III, zespót 396; 247, k. 1v

Annus Domini 1738 vus , Maius. Die 4 ${ }^{\text {ta }}$ Maii, quae fuit Dominica 4. post Pascha, in coadiutorem episcopatus Livoniensis cum titulo episcopatus in partibus Cestrensis, ab Eminentissimo et Reverendissimo Domino Joanne cardinali Lipski, episcopo Cracoviensi, duce Severiae, Kielciis consecratus est Illustrissimus Dominus

${ }^{137}$ Zob. także Szostkiewicz, s. 554; Nitecki, kol. 401; Wiadomości, s. 318 (tamże przyp. 100).

${ }^{138}$ Por. Sarna, t. 2, 427. Zob. także Szostkiewicz, s. 554; Dola (I), s. 266, nr 13; Nitecki, kol. 401-402; Wiadomości, s. 318 (tamże przyp. 101); Przybyszewski, s. 192-194. 
Venceslaus Hieronymus de Bogusławice Sierakowski, protunc coadiutor Livoniensis.

\section{4}

Skotnicki Tomasz biskup (Chetmża)

sakra 13 I 1686 (niedziela) $・$ Toruń $^{139}$

$A D W t, 3-A S W t P$ 6(97cz), k. [167r-v]

Die 13. eiusdem [mensis Januarii] in consecratione Reverendissimi Domini Thomae Bogoriae [k. 167v] Skotnicki, episcopi Licopoliensi, suffraganei Culmensis, assistebam [odnosi się do sufragana włocławskiego Piotra Pawła Mieszkowskiego]. Cuius consecrator [erat] Illustrissimus et Reverendissimus Casimirus de Bnin Opalinski, episcopus Culmensis et Pomeraniae. Assistens primus Reverendissimus Albertus Stawowski, episcopus Petrinensis [recto Petrensis], suffraganeus Gnesnensis, secundus [vero] ego, ut supra. Thorunii, in ecclesia parochiali S. Joannis, in magna frequentia nobilitatis et populi [atque] sacerdotum. Cui solemnitati aderat magistratus [cum] burgrabio et praesidente. Ipse Illustrissimus episcopus concionabatur in medio maioris altari.

\section{5}

Skuminowicz Teodor biskup (Wilno [Białoruś])

sakra 29 IX 1652 (niedziela) $・$ Rzym ${ }^{140}$

ASV, Miscellanea, Armadia XIII 33, k. 222r [220r]

Dominica XIX ${ }^{\circ}$ post Pentecostes, die 29. Septembris anno [1652], Eminentissimus Dominus Marcus Antonius tituli Sanctae Mariae de Pace S.R.E. presbiter cardinalis Franciottus, episcopus olim Lucensis, vigore mandati apostolici, Romae, in basilica S. Mariae Maioris, assistentibus sibi Illustrissimis et Reverendissimis Dominis Joanne Baptista Foppa, archiepiscopo Beneventano, et Rainutio Scotto, episcopo olim Borgo Sancti [Dominici], munus consecrationis impendit Illustrissimo et Reverendissimo Domino Theodoro Skominowicz, Polono, electo Gratianopolitano, [...] praesentibus inter alios Perillustri Reverendo Jacobo Cinomo et Reverendo Domino Nicolao de Michaelibus, presbytero Lucensis dioecesis, testibus [ad praemissa] adhibitis et vocatis.

${ }^{139}$ Por. Frydrychowicz, s. 13-16, nr 4. Zob. także Szostkiewicz, s. 555; Nitecki, kol. 405.

${ }^{140}$ Por. Combaluzier, s. 234, nr 702. Zob. również Szostkiewicz, s. 556; Nitecki, kol. 406. 


\section{6}

Sokotowski Aleksander biskup (Kijów) $\quad$ sakra 16 XI 1636 (niedziela) $・$ Rzym ${ }^{141}$

ASV, Miscellanea, Armadia XIII 33, k. 193v-194r [191v-192r]

Feria $6^{\text {ta }}$ die 14. Novembris 1636, [...] Reverendus Dominus Alexander Sokolovvsky, electus Ecclesiae Chioviensis, [...] praestitit fidelitatis solitum iuramentum in manibus Eminentissimi et Reverendissimi Domini Hipolyti diaconi cardinalis Aldobrandini, praesentibus Illustrissimis Domino Roberto Capilucco, Romano, et Admodum Reverendo Domino Thoma Lellio, presbytero, loci sancti existentibus, nullius dioecesis, testibus etc.

[k. 194r(192r)] Dominica 27 post Pentecosten, die 16 ${ }^{\mathrm{a}}$ Novembris 1636, [...] Eminentissimus et Reverendissimus Dominus Antonius tituli Sanctorum Nerei et Achillei presbyter cardinalis Santacrucius, vigore mandati apostolici ab Sanctissimo Domino nostro habiti, Romae, in ecclesia Nominis Jesu, assistentibus sibi Reverendissimis Dominis Benedicto Lando, olim episcopo Forosemproniensi, et Petro Parczevvsky, episcopo Smolenscensi, consecravit Reverendissimum Dominum Alexandrum Sokolovvsky in episcopum et pastorem Ecclesiae Chioviensis, praesentibus ibidem Illustribus et Admodum Reverendis Domino Ventura de Rubei, Lunensis Sarzanensis [dioecesis], et Domino Co. Roncallo, clerico Romano, testibus etc.

\section{7}

Sokotowski Piotr biskup (Chetmża) sakra 27 VIII 1645 (niedziela) • Toruń142

ADWt, 3-ASWtP 4(97cz), k. $28 r$

Die 27. Augusti [1645] Torunii, in ipsa vigilia colloquii amicabilis cum haereticis ac ministris eorum, in consecratione Reverendissimi Domini [pozostawiono miejsce na wpisanie imienia] Sokolowski in episcopum [pozostawiono miejsce na wpisanie nazwy stolicy tytularnej] ac suffraganeum Culmensem assistentiam praebui [odnosi się do sufragana włocławskiego Piotra Mieszkowskiego] cum Reverendissimo Alberto Tolibowski, suffraganeo Plocensi, consecrante Illustrissimo ac Reverendissimo Domino Georgio Tyszkiewicz, episcopo Samogitiae, praesente Illustrissimo ac Reverendissimo Domino Gasparo Dzialinski, episcopo Culmensi et Pomeraniae.

${ }^{141}$ Por. Korytkowski, t. 3, s. 549; Combaluzier, s. 216, nr 587; Dola (I), s. 279, nr 24 (data sakry 27 XI 1636). Zob. także Szostkiewicz, s. 556; Nitecki, kol. 409.

${ }^{142}$ Por. Frydrychowicz, s. 9-10, nr 1. Zob. także Szostkiewicz, s. 556; Nitecki, kol. 409. 


\section{8}

Starczewski Stanisław biskup (Ptock)

sakra 26 IV 1615 (niedziela) $・$ Puttusk ${ }^{143}$

ADPt, AEp 32(64), s. 857-860

Anno a Nativitate Domini millesimo sexcentesimo quindecimo [...], die vero vigesima sexta mensis Aprilis, ipsa die Dominica in Albis, [...] coram Illustrissimo et Reverendissimo Domino, Domino Martino Szyszkowski, [...] episcopo Plocensi, [...] personaliter constitutus Reverendissimus Dominus Stanislaus Starczewski, confirmatus episcopus Lacedaemoniensis, suffraganeus, abbas et canonicus Plocensis, in ipso actu consecrationis suae in episcopatu per supradictum Illustrissimum et Reverendissimum Dominum, Dominum episcopum Plocensem, in ecclesia collegiata Poltoviensi, dioecesis Plocensis, assistentibus sibi Reverendissimis Dominis Margaritensi et Enensi episcopis, Vladislaviensi et Posnaniensi respective suffraganeis, factae, [praestitit iuramentum fidelitatis].

ADWt, 3-ASWtP 1(63cz), k. 100v

Dominica in Albis, die 26. Aprilis [1615], Reverendissimus Dominus suffraganeus [Vladislaviensis Franciscus Łąnczki], Pultoviae Reverendissimum Dominum [pozostawiono miejsce na wpisanie imienia] Starczewsky, suffraganeum et abbatem Plocensem, in ecclesia collegiata Pultoviensi in episcopum Lacedemoniensem Illustrissimo et Reverendissimo Domino Martino Szyskowsky, episcopo Plocensi, consecratori, cum Reverendissimo Domino Andrea Rychlinsky, suffraganeo Posnaniensi, assistens, consecravit.

\section{9}

Strachwitz Jan Maurycy biskup (Wroctaw)

sakra 17 V 1761 (niedziela) • Kraków ${ }^{144}$

AKMK, LOrd 10, k. 47r

Annus Domini 1761, die 17. Maii. In ecclesia archi-presbyterali Beatae Virginis Mariae in Circulo Cracoviensi, [episcopus Patarensis et suffraganeus Cracoviensis Franciscus Potkański] consecravit in episcopum Tyberiadensem Illustrissimum et Reverendissimum Mauritium De Strachwitz, suffraganeum Wratislaviensem,

${ }^{143}$ Zob. Szostkiewicz, s. 559; Nitecki, kol. 416.

${ }^{144}$ Por. Wiadomości, s. 320; J. Jungnitz, Die Breslauer Weihbischöfe, Breslau 1914, s. 245 (całość biogramu - s. 242-265); J. Pater, Wrocławska kapituła katedralna w XVIII wieku. Ustrój-skład osobowy - działalność, Wrocław 1998, s. 237-238. Zob. także Szostkiewicz, s. 561; Nitecki, kol. 420-421; Polonica, s. 196, nr 214. 
in assistentia Illustrissimi Domini Dominici Kielczewski, suffraganei Chełmensis, et Reverendissimi Domini (de speciali consensu Sedis Apostolicae) Hiacinthi Łopacki, archi-presbyteri infulati et canonici cathedralis Cracoviensis.

\section{0}

Strojnowski Hieronim biskup (Euck - Wilno) sakra 31 I [19 I st.st.] 1808 (niedziela) $\bullet$ Luck $^{145}$

ASV, Archivio Concistoriale, Processus Consistorialis, vol. 210, k. 456r-v (Testimonium consecrationis z daty: Luceoriae, 20 I 1808)

[Nos] Gaspar Casimirus Columna Cieciszowski, Dei et Apostolicae Sedis gratia episcopus Luceoriensis et Zitomiriensis [...], universis et singulis [...] significamus [...], [quod] anno Domini millesimo octingentesimo octavo, Dominica secunda post Epiphaniam, quae fuit dies decima nona mensis Januarii, hic Luceoriae, in ecclesia cathedrali Luceoriensi, assistentibus nobis Illustrissimis Reverendissimis Dominis Stephano Lewinski, episcopo Luceoriensi Ecclesiarum Unitarum, Joanne Chrysostomo Kaczkowski, episcopo Cariopolitano, suffraganeo Luceoriensi, et Joanne Cantio Bozydar Podhorodenski, episcopo Polemonensi, suffraganeo Zitomiriensi, [...] [k.456v] munus consecrationis ipsi [mowa o Hieronimie Strojnowskim] impendimus.

\section{1}

Szaniawski Konstantyn Felicjan biskup (Włocławek - Kraków) sakra 20 II 1707 (niedziela) $・$ Lwów $^{146}$

$A A G n, A C a p B 78, k .10 v$

Annus Domini millesimus septingentesimus septimus. Celsissimus ac Reverendissimus princeps Dominus Stanislaus in Słupow Szembek, Dei et Apostolicae Sedis gratia archiepiscopus Gnesnensis, legatus natus, Regni Poloniae et Magni Ducatus Lithuaniae primas, anno eodem millesimo septingentesimo septimo, Dominica Septuagesimae, quae fuit dies vigesima mensis Februarii, in ecclesia metropolitana Leopoliensi consecravit in episcopum Vladislaviensem et Pomeraniae Illustrissimum ac Reverendissimum Dominum Constantinum Szaniawski.

${ }^{145}$ Por. A. J. Kukuła, Hieronim hrabia Strojnowski. Prawnik - ekonomista - fizjokrata (1752-1815), Lublin 2009, s. 150. Zob. również Dola (I), s. 298, nr 30; Nitecki, kol. 422.

${ }^{146}$ Por. J. Kopiec, Konstanty Felicjan Szaniawski (1668-1732), biskup i mąż stanu za panowania Augusta II, w: Rzeczpospolita wieku wyznań, red. A. Kaźmierczyk i in., Kraków 2004, s. 183 (całość - s. 179-190). Zob. także Szostkiewicz, s. 563; Dola (I), s. 300, nr 55; Nitecki, kol. 426; Wiadomości, s. 320 (tamże przyp. 107). 


\section{2}

Szczuka Kazimierz Jan biskup (Chełmża)

sakra 22 XI 1693 (niedziela) • Warszawa ${ }^{147}$

ADPelp, C 25, k. 5r-v (Consecratio illustrissimi episcopi et possessio episcopatus)

Postquam sacra expeditio cum omibus bullis die decima septima Novembris anni eiusdem [1693] advenerit, mox seguenti [k. 5v] Dominica vigesima secunda eiusdem, processum est ad consecrationem Illustrissimi Casimiri de Szczuki Szczuka, Varsaviae, in ecclesia Sanctimonialium Visitationis [Beatissimae Mariae Virginis]. Munus consecrationis [accepit ab] Illustrissimo [episcopo] Posnaniensi, assistentes Illustrissimis Plocensi et Luceoriensi episcopis exercentibus.

\section{3}

Szedziński Stanisław biskup (Poznań)

sakra 21 XII 1568 (wtorek) $・$ Rzym ${ }^{148}$

ASV, Miscellanea, Armadia XIII 33, k. 29v-30r [26v-27r]

Die Martis XXI. mensis Decembris [1568], in festo Sancti Thomae Apostoli, Reverendissimus Otto Truchses, cardinalis Augustanus nuncupatus, habens facultatem sibi traditam per vivae vocis oraculum a Sanctissimo Domino nostro, consecravit in Capella Magna Palatii, assistentibus sibi Reverendis Dominis Julio Antonio Santorio, archiepiscopo Sanctae Severinae, provinciae Calabriae, et Gulielmo [Cheisholm], episcopo Dumblanensi [k.30r(27r)], Reverendissimos Dominos Stanislaum Sedignium [sic!], suffraganeum Posnaniensem, in episcopum Enensem, et Marcum Teggingerum, suffraganeum Basiliensem, in episcopum Lidensem. Qui Reverendi Domini electi praestiterunt consueta iuramenta in manibus praedicti Reverendissimi Domini consecratoris, praesentibus Reverendo Domino Nicolao Fameano[?], presbytero Ferrariensis dioecesis, et Pÿrro Riccio de Trevio, clerico Spoletanensis dioecesis.

\section{4}

Szembek Krzysztof Jan biskup (Chełm/Krasnystaw - Przemyśl - Warmia) sakra 27 VIII 1713 (niedziela) $\bullet$ Eowicz ${ }^{149}$

${ }^{147}$ Zob. także Szostkiewicz, s. 563; Dola (I), s. 260, nr 41; Nitecki, kol. 427.

${ }^{148}$ Por. Combaluzier, s. 133, nr 45. Zob. także Szostkiewicz, s. 566 (mylna forma nazwiska Szeziński); Nowacki, t. 2, s. 185, nr 15; Nitecki, kol. 428.

${ }^{149}$ Por. Pawelec, cz. 6, s. 396-397, nr 44. Zob. także Szostkiewicz, s. 565; Dola (I), s. 258, nr 36; Nitecki, kol. 431; Wiadomości, s. 321 (tamże przyp. 111); Przybyszewski, s. 218-219; Szczepaniak, Duchowieństwo diecezji krakowskiej w XVIII wieku, s. 704-705. 
ADWt, 3-ASWtP 8(98cz), k. 50r (zob. również tamże, k. 33r, gdzie wskazówka odnośnie do miejsca i-pośrednio-czasu sakry także W.I. Bardzińskiego, którypierwszych wswej postudze biskupiej święceń udzielit na Jasnej Górze klerykom paulińskim ,anno Domini 1709, Sabbatho decima Augusti, redeundo Opavii post consecrationem [suam]")

Anno eodem [1713], mensis 27. Augusti, cum Illustrissimo et Reverendissimo Domino Adamo Rostkowski, suffraganeo Luceoriensi, assistebamus [odnosi sie do sufragana włocławskiego Wojciecha Ignacego Bardzińskiego] consecrationi Illustrissimi et Reverendissimi Domini, Domini Christophori Szembek, Dei gratia episcopi Helmensis, quem Celsissimus princeps [Stanislaus Szembek], princeps archiepiscopus Gnesnensis, primas Regni, tanquam fratrem suum germanum consecravit Loviciis, in assistentia Illustrissimorum Joannis [Szembek], cancellarii Regni, et [pozostawiono puste miejsce], vexilliferi Regni, germanorum fratrum, et magnifici castellani Visliciensis, patruelis.

AAWO, AK Ab 28, k. 1v (Copia listu Jasnie Wielmoznego Jegomości Xiędza nominata chetmskiego do Jasnie Wielmoznego Jegomości Xiędza suffragana krakowskiego). Zob. również tamże, k. $2 r$ (Copia listu Jmci Xiędza rektora zamoyskiego imieniem całey Akademii Zamoyskiey do Jasnie Wielmożnego Jmci Xiędza biskupa chetmskiego) oraz k. 3r (Copia listu Xiążęcia Jegomości biskupa krakowskiego do tegoż Jegomości z Krakowa 14. Augusti 1713): „, Nie cięszko by mi było iechać ad actum consecrationis z życzliwego afektu ku Wielce Miłościwemu Waszmości Panu, bo bym byt mogt dwie rzeczy lucrari gloriam obsequii y sobie wielkie ukontentowanie ex visione Xiązęcia Jmci prymasa y Jmci Pana kanclerza wielkiego koronnego, moich Wielce Miłościwych Panow, ale w tak krotkim czasie wybrać się niepodobna et ipsa pericula od kamieńca wstręt czynią. Bęndę tam iednak, da Bog, sercem praesens, suspirando, aby plenitudo benedictionum per sanctas manus Xiążęcia Jmci Najmiłościwszego Pana effusa descendat na osobę Wielce Miłościwego Waszmości Pana cum charactere episcopali charismata imprimum, które in decus magnarum qualitatum Wielce Miłościwego Waszmości Pana Kościołowi y Oyczyznie in futurum perennent”.

Kiedy łaskawie Xiąże Jmć Dobrodziey [mowa o prymasie Stanisławie Szembeku] determinować raczył w Łowiczu actum consecrationis meae pro die 27. Augusti currentis, znaiąc tak wiele łask mnie świadczonych od Wielce Miłościwego Waszmości Pana y Dobrodzieya, upraszam przy nayniszszym pokłonie o tę, ktora mnie potkać może naypryncypalnieysza y najosobliwsza, ażebyś poządaney prezencji swoiey honor przydać mnie raczył Wielce Miłościwy Waszmość Pan y oraz consecrationis munus na siebie wziąwszy assistere gratiosissima instructione numerum takze Fratrum beare y mnie na tęnze Alet benedictione sua speciali adesse. 


\section{5}

Szembek Michat biskup (Kraków)

sakra 30 XI $1706($ wtorek $) \cdot$ Kraków $^{150}$

AKMK, LOrd 6, s. 305-306; LOrd 7, s. 25

Illustrissimus et Reverendissimus Dominus, Dominus Casimirus a Łubna Łubienski, Dei et Apostolicae Sedis gratia episcopus Chelmensis, canonicus, sede vacante episcopatus Cracoviensis ac Ducatus Severiensis generalis administrator, perpetuus commendatarius abbas Czerviensis [sic!], anno ut supra [1706], in festo S. Andreae Apostoli, quae fuit 30. Novembris, in ecclesia cathedrali Cracoviensis, infra missarum solennia, consecravit Perillustrem ac Reverendissimum Dominum, Dominum Michaelem a Słupow Szembek, decanum Cracoviensem, in episcopum Paphensem et suffraganeum Cracoviensem, cum assistentia Illustrissimorum [s. 306] et Reverendissimorum Dominorum episcoporum, nempe Joannis Skarbek, episcopi Marochiensis, suffraganei, custodis Leopoliensis, et Stanislai Bieganski, episcopi per utramque Valachiam Bachoviensis, tumque in assistentia multorum procerum Regni Poloniae ad hunc actum rogatum.

\section{6}

Szembek Stanistaw biskup (Kraków - Włocławek - Gniezno) sakra 5 III 1690 (niedziela) $\cdot$ Warszawa ${ }^{151}$

AKMK, LOrd 5, k. 254r-v

Perillustris Dominus Stanislaus in Słupow Szembek, praepositus in Magna Xiąż, consecratus [est] in episcopum Dionisiae anno Domini 1690, Dominica ipsa Laetare, Varsaviae, in ecclesia Monialium Visitationis Beatissimae Mariae Virginis, per Illustrissimum et Reverendissimum Joannem de Małachowice Małachowski, episcopum Cracoviensem, Ducatus Severiensis principem, et assistens eidem Illustrissimos et Reverendissimos Dominos, Dominos Joannem de Zbąszyn [j. 254v] Zbąski, episcopum Varmiensem, et Andream Załuski, [episcopum] Kiioviensem.

\section{7}

Szołdrski Andrzej biskup (Kijów - Przemyśl - Poznań) sakra 11 VI 1634 (niedziela) $\bullet$ Lowicz $^{152}$

${ }^{150}$ Por. Przybyszewski, s. 220. Zob. także Szostkiewicz, s. 565; Nitecki, kol. 431.

${ }^{151}$ Por. Andreae Chrysostomi in Zatuskie Zatuski [...] epistolarum historio-familiarum tomi $I^{m i}$ pars II., Brunsbergae 1710, s. 1168 (,,5 ta $^{\text {ta }}$ Martii [1690] episcopus Cracoviensis suffraganeum suum Stanislaum Szembeck in episcopum consecravit"). Zob. także Szostkiewicz, s. 565; Nitecki, kol. 431-432. Nadto: Polonica, s. 197, nr 225.

${ }^{152}$ Zob. Szostkiewicz, s. 566; Nowacki, t. 2, s. 106; Dola (I), s. 270, nr 24; Nitecki, kol. 434. 
ASV, Archivio Concistoriale, Processus Consistorialis, vol. 33, k. 1099r. (document notarialny sporzadzit ,,Venceslaus Ceynarovic, iuris utriusque doctor, Loviciensis Varsaviensisque canonicus, sacra authoritate apostolica publicus et actorum Curiae Illustrissimi Domini archiepiscopi Gnesnensi notarius"') ${ }^{153}$

In nomine Domini Amen. Praesenti publice instrumento cunctis pateat evidenter et sit notum, qualiter anno Domini millesimo sexcentesimo trigesimo quarto, indictione Romana II., Dominica Sanctisimae Trinitatis, quae fuit dies XI mensis Junii, pontificatus Sanctissimi Domini nostri Domini Urbani Papae VIII. anno XII, in notarii publici testiumque infrascriptorum praesentia, constitutus personaliter Illustrissimus et Reverendissimus Dominus Andreas Szoldrski, electus et confirmatus episcopus Kiioviensis, coram Illustrissimo Domino Joanne Wezyk, Dei et Apostolicae Sedis gratia archiepiscopo Gnesnensi, legato nato, Regni Poloniae primate primoque principe, exhibuit literas pargameneas sub plumbo appenso more Romanae Curiae expedito, sanas, integras omnique vitio suspitionis careas, continentes in se mandatum apostolicum de et super obtinenda consecratione sui in episcopum a quocunque antistite Catholico prout in eisdem literis latius continebatur, petiittque ad executionem earum literarum procedi seque in episcopum consecrari omni meliori modo etc. Et Illustrissimus Dominus archiepiscopus, receptis literis apostolicis cum ea qua decet reverentia, cum ipsemet ob graves dolores chirogricam [hydrogricam] et podagricam munus consecrationis obire non potuisset, usus est opera Perillustris et Reverendissimi Domini Stanislai Starczewski, episcopi Laodicensi, suffraganei Plocensi, ipse vero una cum Perillustri et Reverendissimo Joanne Baykowski, episcopo Ennensi suffraganeoque Posnaniensi, assistentem egit. Sicque praefatus Illustrissimus Dominus Andreas Szołdrski, facta professione fidei Catholica, iuxta formam in literis bullae praescriptam, a suprapraefato Reverendissimo Domino suffraganeo Plocensi, assistentibus supranominatis Illustrissimo Domino archiepiscopo et Reverendissimo suffraganeo Posnaniensi, iuxta praescripta Pontificalis Romani, in episcopum consecratus est. Cuius quidem consecrationis modo quo supra factae, ut sibi testimonium darem et super ea re praesens publicum instrumentum vel plura conficerem sibique authentice extraderem, idem Illustrissimus Dominus consecratus debita cum instantia postulavit. Acta sunt haec in ecclesia collegiata Loviciensi Beatissimae Mariae Virginis, anno, indictione, die, mense, pontificatu, quibus supra, praesentibus Admodum Reverendis, Generosis et Illustribus Dominis Samuele Przeclawski, cantore Sandomiriensi, Gnesnensi Loviciensique canonico, Sacrae Regiae Maiestatis secretario, Adriano Grodecki, archidiacono Curzeloviensi, custode Loviciensi canonicoque Gnesnensi, Joanne Legowski, iuris utriusque doctore, archidiacono Loviciensi, cancellario etc. Crusviciensi, Petro Małoklęski, Loviciensi Unieioviensique, Venceslao Kunicki, Loviciensi, Mathia Miedniewski, Lenciciensi, canonicis, Joanne Wezyk, capitaneo Syradiensi, Nicolao Lasciszewski, notario terrestri Ravensi capitaneoque Loviciensi, Jacobo de Roniszewice Stokowski, subdapifero Lenciciensi, Adamo Wezyk, thesaurario Lenciciensi, Petro Sławinski,

${ }^{153}$ Por. L. Królik, Kapituła kolegiacka w Warszawie do końca XVIII wieku, Warszawa 1990, s. $186, \mathrm{nr} 32$. 
iudice castrensi Loviciensi, Alberto Strubicz, Petro Krasuski, Joanne Rozniatowski et allis plurimis praelatis, canonicis et nobilibus personis circa praemissa existentibus.

\section{8}

Tarto Jan Joachim biskup (Kijów - Poznań)

sakra 23 IV 1719 (niedziela) $・$ Kraków $^{154}$

AKMK, LOrd 6, s. 545

Illustrissimus et Reverendissimus Dominus Michaël in Słupow Szembek, episcopus Paphensis, suffraganeus et decanus Cracoviensis, consecravit magno populo concursu in circulo ecclesiae archipresbyteralis Cracoviensis Beatae Mariae Virginis Illustrissimum et Reverendissimum Dominum Joannem de Czekarzowice Tarło, episcopum Kijoviensem, et Reverendissimum Stanislaum de Bezdan Hosium, suffraganeum Przemysliensem cum honore episcopatus Uticensis, in assistentia Illustrissimi et Reverendissimi Domini Petri Tarło, suffraganei Posnaniensi, nominati Livoniensi, et Illustrissimi et Reverendissimi [pozostawiono miejsce na wpisanie imienia] Szaniawski, suffraganei Leopoliensi, anno ut supra 1719, die vero 23. Aprilis.

AAPzn, $A S O$ 7, k. $3 r$

Consecratio Illustrissimi, Excellentissimi et Reverendissimi Domini Joannis de Czekarzewice Tarło in episcopum Kijoviensem, post decessum piae memoriae Illustrissimi et Reverendissimi Domini Arcemberski, fuit Cracoviae in archypraesbyterali ecclesia in Circulo anno Domini 1719, ipso festo S. Adalberti Episcopi et Martyris, in Dominicam $2^{\frac{\text { ndam }}{}}$ post Pascha incidente. Consecrator praefati Illustrissimi Domini fuit Illustrissimus et Reverendissimus Dominus Michael a Słupow Szembek, Dei et Apostolicae Sedis gratia episcopus Paphensis, suffraganeus, decanus, vicarius in spiritualibus et officialis generalis Cracoviensis, assistentibus Illustrissimis et Reverendissimis Dominis Petro de Czekarzewice Tarło, episcopo Claudiopolitano, nominato Livoniae, suffraganeo, praeposito, vicario in spiritualibus et officiali generali Posnaniensi, abbate commendatario Paradisiensi, et Feliciano Szaniawski, episcopo Capsensi, suffraganeo, canonico Leopoliensi.

${ }^{154}$ Por. Przybyszewski, s. 224. Zob. także Szostkiewicz, s. 569; Nowacki, t. 2, s. 111; Dola (I), s. 271, nr 33; Nitecki, kol. 132; Wiadomości, s. 323 (tamże przyp. 117); Szczepaniak, Duchowieństwo diecezji krakowskiej w XVIII wieku, s. 708. 


\title{
149
}

\author{
Toczyłowski (Samson-Toczyłowski) Piotr Aleksander biskup (Wilno) \\ sakra 29 XII 1782 (niedziela) • Wilno ${ }^{155}$
}

APBKr, S-Wi-4, s. 312

Hac die, scilicet 29. Decembris [1782], in qua incipit Dominica infra Nativitatem Domini Nostri Jesu Christi, Celsissimus loci ordinarius, in assistentia numerosorum illustrissimorum dominorum praelatorum, canonicorum aliarumque spiritualium personarum, in praesentia quoque numerose congregatorum dominationum, cum magna solemnitate in ecclesia S. Joannis parochiali consecravit Illustrissimos, Reverendissimos Dominos Petrum Samsonem Toczyłowski, cantorem ac officialem generalem Vilnensem, in episcopum Bellinensem ac suffraganeum Vilnensem, ac Illustrissimum, Reverendissimum Dominum Franciscum Gzowski, canonicum nec non surrogatum Vilnensem, in episcopum Tespiensem et suffraganeum Trocensem. Con-consecratores fuere Illustrissimi, Reverendissimi Domini Zienkowicz, episcopus Ariopolitanus, et Wołczacki, episcopus Tomassensis.

\section{0}

Tolibowski Wojciech biskup (Płock - Poznań)

sakra 1 I 1645 (niedziela) • Warszawa ${ }^{156}$

ADPt, AEp 37(54), s. 595-597 (Facultas exercendi pontificalia Reverendissimo Domino suffraganeo Plocensi - dokument królewicza Karola Ferdynanda Wazy z 26 I 1645)

Carolus Ferdinandus, Dei gratia princeps Poloniae et Sueciae, episcopus Plocensis etc., Reverendissimo Domino Alberto Tholibowski, Dei et Apostolicae Sedis gratia episcopo Lacedaemoniensi, suffraganeo nostro, praeposito S. Mariae Magdalenae et canonico Plocensi. [...] Reverendissima Dominatio Vestra per consecrationem sui in ecclesia Patrum Societatis Jesu Varsaviae ipso festo Circumcisionis Domini anni praesentis [1645], in nostra praesentia rite celebratum, munus suffraganei in ecclesia nostra cathedrali Plocensi ex dispositione Divina voluntateque nostra obtinuit.

${ }^{155}$ Por. Wiadomości, s. 323; Polonica, s. 198, nr 230; Kasabuła, Ignacy Massalski, biskup wileński, s. 152. Zob. także Szostkiewicz, s. 570; Nitecki, kol. 448.

${ }^{156}$ Por. A.S. Radziwiłt, Memoriale rerum gestarum in Polonia 1632-1656, t. 3 - 1640-1647, Wrocław 1972, s. 195 („Prima Januarii [1645] princeps Carolus [Ferdinandus] suffraganeum Plocensem Tulibovium consecrari fecerat apud Patres Societatis et postea egregio convivio ibidem totam aulam excepit. Rex debuit adesse, at pedogra detentus praesentiam suam regiam subtraxit"). Zob. także Szostkiewicz, s. 571; Nowacki, t. 2, s. 107; Nitecki, kol. 449. 


\section{1}

Trzemeski Kasper biskup (Gniezno)

sakra 11 IX 1661 (niedziela) $\bullet$ Lowicz $^{157}$

ADWt, 3-ASWtP 5(97cz), k. 61v-62r

Eodem anno ut supra [1661], die vero undecima mensis Septembris, Dominica vero decima quarta post Pentecostes, in ecclesia collegiata maiori Loviciensi, Perillustris Reverendissimus Dominus episcopus Margarithensis et suffraganeus Vladislaviensis, una cum Perillustribus et Reverendissimis Dominis suffraganeis Plocensi et Leopoliensi, consecravit solenniter Perillustrem et Reverendissimum Dominum [pozostawiono miejsce na wpisanie imienia] Trzemeski pro episcopatu Argiviensi, suffraganeatu Gnesnensi [...], in magna frequentia utriusque status.

\section{2}

Tyszkiewicz Antoni Dominik biskup (Kijów - Żmudź/Miedniki) sakra 11 X 1739 (niedziela) $\cdot$ Wilno $^{158}$

BN, BOZ 941, s. 305

[Mens] October 1739. Po zaczętej octobrowej kapitule, w katedrze ${ }^{\mathrm{a}-}$ wileńskiej ${ }^{\mathrm{a}}$, biskup wileński in assistentia mea [autorem zapiski biskup koadiutor wileński Józef Julian Sapieha] y suffragana żmudzkiego konsekrował Tyszkiewicza, sekretarza litewskiego, na biskupstwo mennitenskie przy suffraganii kijowskiej.

\section{3}

Uchański Jakub arcybiskup (Chełm/Krasnystaw - Włocławek - Gniezno) sakra 20 III $1552($ niedziela $) \cdot$ Piotrków $^{159}$

AKapMK, AAct 5, k. 43r (Crida super Biezanow et domo)

a-a wyraz przekreślony

${ }^{157}$ Por. Korytkowski, t. 4, s. 141 (tamże przyp. 2 na s. 141-142). Zob. również Szostkiewicz, s. 574; Nitecki, kol. 454 (data sakry 11 VI 1661).

${ }^{158}$ Por. Wiadomości, s. 324 (tamże przyp. 121); Wołonczewski, Biskupstwo żmujdzkie, s. 97. Zob. także Szostkiewicz, s. 576; Nitecki, kol. 458.

${ }^{159}$ Por. T. Wierzbowski, Jakub Uchański, arcybiskup gnieźnieński, 1502-1581. Monografia historyczna, Warszawa 1895, s. 91-96; Pawelec, cz. 6, s. 391, nr 17. Zob. także Szostkiewicz, s. 576-577; Dola (I), s. 258, nr 17; Nitecki, kol. 461. 
Reverendi domini [capitulum Cracoviense] facti certiores Reverendum Dominum Jacobum Vchanski, canonicum Cracoviensem, antea nominatum, nuper vero, hoc est die Dominico Oculi, Piotrcoviae, in conventione generali, ad episcopatum Chelmensem esse consecratum. Quare inhaerentes consuetudini veteri et statutorum suorum dispositioni, litteras cittationis in vim cridae super optione et distributione villae praestimonialis Biezanow et domus capitularis, quarum est possessor, sic per munus consecrationis ipso facto vacantibus decernendas, et in valvis ecclesiae huius aliquo die festo publicandas et exequendas duxerunt et mandaverunt.

\section{4}

Wątróbka (ze Strzelec) Jan arcybiskup (Lwów)

sakra $20 \mathrm{~V} 1481$ (niedziela) $\bullet$ Rzym ${ }^{160}$

ASV, Camera Apostolica, Libri Formatarum 7, k. $14 v$ (Litterae muneris consecrationis pro Domino Joanne, electo Leopoliensi)

Universis et singulis [notum facimus], quod Reverendus in Christo Pater Dominus Stephanus, Dei gratia archiepiscopus Antibarensis, in Romana Curia residens, ex papali commissione iura[?] de mandato Sanctissimi in Christo Patris et Domini nostri, Domini Sixti IV Papae, hoc vive vocis oraculo [...], in ecclesia Sancti Bernardi de Urbe prope Columam Montium, assistentibus sibi Reverendis in Christo Patris Dominis Andreae, archiepiscopo Craynensi, et Julio, episcopo Berthonoriensi, die dato praesentium, Reverendo Patri Domino Johanni, electo Leopoliensi, munus consecrationis ritus episcopalis impendi solitum et solemnem infra missarum solemnia rite et legaliter in Dei nomine contulit et impedit iuxta formam etc. Datum Romae, in Camera Apostolica apud Sanctum Petrum, anno a Nativitate Domini $\mathrm{M}^{\circ} \mathrm{CCCCLXXX}{ }^{\circ}$ primo, indictione XIIII ${ }^{a}$, die XX. mensis Maii, pontificatus [...] Sanctissimi Domini nostri, Domini Sixti Papae IIII. anno $X^{\circ}$.

\section{5}

Wessel Adam Augustyn biskup (Inflanty/Wenden - Kamieniec) sakra 6 VIII 1724 (niedziela) $\cdot$ Warszawa ${ }^{161}$

AAPzn, ASO 8, k. [16v]

Varsaviae, die 6. Augusti [1724], Dominica 12. post Pentecosten, Illustrissimus [episcopus Camenecensis Stanislaus Josephus Hosius] fuit assistens consecrationi

${ }^{160}$ Por. Krętosz, Organizacja archidiecezji lwowskiej, s. 69, nr 11. Zob. także Szostkiewicz, s. 561 (pod nazwiskiem Strzelecki); Dola (I), s. 277, nr 4; Nitecki, kol. 170-171.

${ }^{161}$ Zob. także Szostkiewicz, s. 581; Dola (I), s. 266, nr 11; Nitecki, kol. 474; Wiadomości, s. 324 (tamże przyp. 122). 
Illustrissimi Wessel, episcopi Livoniensi. Consecrator Illustrissimus Santini, nuncius apostolicus; secundus assistens Illustrissimus Załuski, episcopus Plocensis; apud Patrum Theatinorum.

\section{6}

Wielewiejski (Wielowiejski) Lukasz Krzysztof biskup ([?])

sakra 29 IX $1726($ niedziela $) \cdot$ Rzym $^{162}$

Archivio dell'Ufficio delle Celebrazioni Liturgiche del Sommo Pontefice (Watykan), 573, s. 580

Die 29. Septembris [1726], Dominica et festo Sancti Michaelis Arc[h]angeli, Sanctissimus Dominus Noster [Benedictus XIII] hoc mane in Capella Paulina Quirinalis Palatii munus consecrationis impendit Reverendissimis Joannis Petro Faccoli, electo Ecclesiae Trojanensi, et Christophoro Wielevieyski, natione Polono, electo Ecclesiae Cambysopolitanensi in partibus, assistentibus sibi Reverendissimis Francisco Finy, archiepiscopo Damascensi, et Nicolao Saverio Santamaria, episcopo Cyrenensi, et omnia de more facta fuerunt; deinde Papa descendit de more ad inserviendum mensae 12. pauperum.

Wielogłowski Hieronim biskup (Przemyśl)

sakra 28 VI 1761 (niedziela) $・$ Kraków ${ }^{163}$

AKMK, LOrd 10, k. 48r

Die 28. Junii 1761, in ecclesia conventuali Patrum Trinitariorum Casimiriae ad Cracoviam, [suffraganeus Cracoviensis Franciscus Potkański] conconsecravit Illustrissimum et Reverendissimum Dominum Hieronymum Wielogłowski in episcopum Bendensem et suffraganeum Premisliensem.

\section{8}

Wierzbowski Hieronim biskup (Poznań)

sakra 12 IV $1682\left(\right.$ niedziela) $\bullet$ Warszawa ${ }^{164}$

${ }^{162}$ Por. „Diario Ordinario”, nr 1430 z 5 X 1726, s. 3.

${ }^{163}$ Por. Wiadomości, s. 325 (tamże przyp. 125); Przybyszewski, s. 238. Zob. także Szostkiewicz, s. 582; Nitecki, kol. 476; Szczepaniak, Duchowieństwo diecezji krakowskiej w XVIII wieku, s. 717.

${ }^{164}$ Por. Nowacki, t. 2, s. 188, nr 25. Zob. także Szostkiewicz, s. 582; Nitecki, kol. 477. 
AAPzn, ASO 6, k. 3r

Ego Hieronymus de Magna Chrząstow Wierzbowski consecratus sum in episcopum Fessensem ab Illustrissimo et Reverendissimo Domino Opicio Pallavicino, archiepiscopo Ephesino, Sanctissimi Domini Nostri Innocentii Divina providentia Papae XI praelato domestico et assistente eiusdemque Sedis Apostolicae apud Serenissimum et Potentissimum Joannem III., Dei gratia regem Poloniae totumque Regnum ac Magnum Ducatum Litwaniae nuncio apostolico, assistentibus Illustrissimis Reverendissimo Domino Stephano Wierzbowski, episcopo Posnaniensi, [...] [et] Reverendissimo Witwiczki, episcopo Kiioviensi, nominato Luceoriensi, in ecclesia collegiata Warsaviensi, Dominica secunda post Pascha, quae fuit 12. Aprilis anno 1682.

\section{9}

Wierzchlejski Franciszek Ksawery arcybiskup (Przemyśl - Lwów) sakra 4 X 1846 (niedziela) • Lwów ${ }^{165}$

ASV, Archivio Concistoriale, Processus Consistorialis, vol. 257, bp. (Testimonium)

Vigore praesentium testor, Illustrissimum ac Reverendissimum Dominum Franciscum Xaverium Wierzchlejski, Premisliensem Latini ritus episcopum [...], Leopoli, die 4 ${ }^{\text {ta }}$ Octobris 1846 munus consecrationis suscepisse, cui solemnitati personaliter interfui, et eo tunc episcopus Pompejopolitanus in partibus infidelium et auxiliaris p. f. Michaelis Lewicki, archiepiscopi Leopoliensis, consecratori assistens, meas quoque manus consecrando imposui. [...] Viennae, 13aㅡ Martii 1860. Gregorius liber baro Jachimowicz, Catholicorum Rutheni ritus episcopus Premisliensis.

\section{0}

Wilkxycki Baltazar biskup (Poznań)

sakra $10 X 1728$ (niedziela) $・$ Poznañ ${ }^{166}$

AAPzn, ASO 7, k. 56v-57r

Anno Domini millesimo septingentesimo vigesimo octavo, die decima Octobris, quae erat Dominica vigesima prima post Pentecosten, in festo gratiarum actionis pro victoria ex Turcis, Posnaniae, in ecclesia cathedrali, consecranti Illustrissimo, Excellentissimo et Reverendissimo Joanne Joachymo comiti de Tęczyn et Czekarzewice Tarło, episcopo Posnaniensi, Illustrissimum et Reverendissimum

${ }^{165}$ Por. Polonica, s. 199, nr 238 (również, nr 239). Zob. także Sarna, t. 2, s. 542; Dola (I), s. 291, nr 59; Nitecki, kol. 478-479.

${ }^{166}$ Por. Nowacki, t. 2, s. 189, nr 29. Zob. także Szostkiewicz, s. 584; Nitecki, kol. 482. 
Balthazarum Wilxycki in episcopum Eucarpiensem et suffraganeum [k. 57r] Posnaniensem, adstitit tanquam conconsecrans Illustrissimus et Reverendissimum Franciscus Kraszkowski, episcopus Dardaniensis, suffraganeus Gnesnensis, abbas commendatarius Vitoviensis, una cum Illustrissimo, Reverendissimo Wi[e]lowieyski, episcopo Cambisopolitano.

\section{1}

Wilkxycki Jan Jerzy biskup (Chetmża)

sakra $4 X 1818$ (niedziela) $\bullet$ Chetmża ${ }^{167}$

ADPelp, C 54a [V 23], s. 202 (tytutowa): „Series ordinatorum ab Illustrissimo ac Reverendissimo Domino Joanne Georgio de Natęcz Wilkxycki, Dei et Apostolicae Sedis gratia episcopo Flavianopolitano, suffraganeo Culmensi, consecrato per Illustrissimum, Reverendissimum Dominum Felicem Lewiński, episcopum Podlachiae, in ecclesia cathedrali Culmensi die $4^{a}$ Octobris, quae erat Dominica 21. post Pentecosten, $1818^{\prime \prime}$.

\section{2}

Witosławski Michał biskup (Przemyśl)

sakra 24 IV 1768 (niedziela) $・$ Dunajów ${ }^{168}$

AGAD, Dziat III, zespót 396; 247, k. 70r

Anno Domini 1768, die 24. Aprilis, quae fuit Dominica $3^{\text {tia }}$ post Pascha, in ecclesia parochiali Dunajoviensi solenni ritu consecravit [archiepiscopus Leopoliensis Venceslaus Hieronymus Sierakowski] Illustrissimum et Reverendissimum Michaelem Witosławski, suffraganeum et decanum Premisliensem, ad episcopatum Coronensem, assistentibus sibi Illustrissimis et Reverendissimis Samuele Głowinski, episcopo Hebronensi, suffraganeo Leopoliensi, et Raymundo Jezierski, episcopo Baccoviensi, praesentibus Magnificis Josepho Skorupka Padlewski, iudice terrestri Leopoliensi, Christophoro Żurowski, vexillifero dictrictus Żydaczoviensis, [...] et aliis ad hunc actum congregatis et invitatis, faces, panes et barilia vini ad offertorium ferentibus.

${ }^{167}$ Por. Polonica, s. 199, nr 240; Frydrychowicz, s. 35 (całość biogramu - s. 33-38). Zob. także Nitecki, kol. 482; Chodyński, s. 77.

${ }^{168}$ Zob. Szostkiewicz, s. 585; Nitecki, kol. 484; Wiadomości, s. 325 (tamże przyp. 126). 


\section{3}

Wojtarowicz Józef Grzegorz biskup (Tarnów)

sakra 22 XI $1840\left(\right.$ niedziela) $\bullet$ Przemyśl $l^{169}$

AAPrzem, 149, s. 87

Die 22. Novembris 1840, quae erat 24. Dominica post Pentecostes, consecravi [odnosi się do biskupa przemyskiego Franiszka Ksawerego Zachariasiewicza] episcopum Tarnoviensem Josephum Woytarowicz, praepositum capituli Premisliensis.

\section{4}

Wolicki Teofil arcybiskup (Gniezno-Poznań)

sakra 17 V 1829 (niedziela) • Poznańn 170

AAGn, ACons G II 5, k. 29v

Anno [...] millesimo octingentesimo vigesimo nono, Dominica quarta post Pascha, videlicet 17. mensis Maii, in ecclesia metropolitana Posnaniensi, ego infrascriptus [Martinus Siemieński], episcopus Cyrenensis, suffraganeus Gnesnensis, [...] munus consecrationis Excellentissimi, Reverendissimi Domini Theophili Wolicki, electi et confirmati archiepiscopi Gnesnensis et Posnaniensis, recepto ab eodem iuxta formam praescriptam [...] fidelitatis iuramento [...], explevi, Reverendissimis Dominis Beda Ostaszewski, Ordinis S. Benedicti Lubinensi, Edvardo Markowski, Ordinis Canonicroum Lateranensium S. Augustini Tremesnensi, abbatibus, loco episcoporum vi specialis indulti apostolici, huiusmodi consecrationis assistentibus.

\section{5}

Wołczacki (Woltczacki) Walenty biskup ([?]) sakra 31 VII 1774 (niedziela) $\cdot$ Warszawa $a^{171}$

ASV, Fondo Garampi, 73, s. 756

${ }^{169}$ Por. A. Jedynak, Z chłopskiej zagrody na biskupia stolicę. Biskup Józef Grzegorz Wojtarowicz (1791-1875), ordynariusz tarnowski (1840-1850), Tuchów 1998, s. 77. Zob. Dola (I), s. 294, nr 6; Kumor, Diecezja tarnowska, s. 266; Nitecki, kol. 489; Polonica, s. 200, nr 245.

${ }^{170}$ Por. Polonica, s. 201, nr 249; Nowacki, t. 2, s. 115-116. Zob. również Dola (I), s. 265, nr 70; Nitecki, kol. 491-492.

${ }^{171}$ Por. Wiadomości, s. 326. 
Domenica 31. Luglio 1774. Questa mattina ho fatto [odnosi sie do autora zapiski, nuncjusza G. Garampiego] la consecrazione del Padre Wołłczacki, Domenicano, in vescovo Tomassense in partibus infidelium, nella chiesa dei Domenicani, assistendovi Mons. Wodzicki, vescovo di Smolensco, e Mons. Okęcki, vescovo di Chelma. Non avendo egli trovato altro vescovo, a cui fosse comodo a consecrarlo, mi espose la sua angustia; onde mi chiese se volessi io di servirlo. I due assistenti si trovarono alla chiesa. Il consecrando venne a levarmi di casa, e in carozza gli diedi la mano diritta. Invitai poi tutti i suoi e altri a pranzo.

\section{6}

Wyżycki Mikołaj Ignacy arcybiskup (Lwów) sakra 7 VII 1737 (niedziela) $\bullet$ Wschowa $^{172}$

AKapMK, LA 36, s. 27

Anno Domini 1737, die 7. mensis Julii, Wschovae, in ecclesia parochiali Wschovensi, Illustrissimus Dominus [episcopus Cracoviensis] consecravit Illustrissimum et Reverendissimum Dominum Wyżycki, archiepiscopum Leopoliensem.

AGAD, Dziat VI, II-80a, s. 839

Die 7. Julii 1737 [Wschowa]. Z rana byłem na pokojach [autorem zapiski Michat Kazimierz Radziwitt] i miałem audiencję u króla [...]. Potem z [Najjaśniejszym] Panem byliśmy w kościele farnym [wschowskim] i asystowaliśmy konsekracji arcybiskupa lwowskiego, księdza Wyżyckiego, którego konsekrował Lipski, [biskup] krakowski, [główny] celebrant, [oraz biskupi] Załuski, łucki, [i] Dembowski, płocki, asystenci.

\section{7}

Zachariasiewicz (Zachariaszewicz) Franciszek Ksawery biskup (Tarnów - Przemyśl)

sakra 24 IV $1836\left(\right.$ niedziela) $・$ Lwów ${ }^{173}$

ASV, Archivio Concistoriale, Processus Consistorialis, vol. 242, k. 525r (Testimonium consecrationis)

${ }^{172}$ Por. Wiadomości, s. 327 (tamże przyp. 132); Sarna, t. 2, s. 535; Krętosz, Organizacja archidiecezji lwowskiej, s. 72, nr 30. Zob. także Szostkiewicz, s. 591; Dola (I), s. 278, nr 23; Nitecki, kol. 501-502; Przybyszewski, s. 245-246.

${ }^{173}$ Por. Polonica, s. 202, nr 255 (także, nr 256). Zob. również Sarna, t. 2, s. 535; Dola (I), s. 294 , nr 5; Kumor, Diecezja tarnowska, s. 263; Nitecki, kol. 503. 
[Nos] Franciscus de Paula Pistek, Dei et Apostolicae Sedis gratia archiepiscopus metropolitanus Leopoliensis ritus Latini, Regnorum Galiciae et Lodomeriae primas, Sacrae Caesareo-Regiae Maiestatis actualis intimus consiliarius etc., omnibus et singulis notum testatumque facimus, quia nos anno post Incarnationem Domini millesimo octingentesimo trigesimo sexto, die vigesima quarta mensis Aprilis, quae tunc fuit Dominica tertia post Pascha, in nostra metropolitana Leopoliensis ritus Latini ecclesia solemniter sacrum missae sacrificium celebrantes, Illustrissimum ac Reverendissimum Dominum Franciscum Xaverium de Zachariasiewicz, pro tunc custodem ecclesiae metropolitanae Leopoliensis ritus Latini, ab Augustissimo imperatore Austriae nominatum et a Sacra Sede Romana confirmatum episcopum Tarnoviensem, adiuvante gratia Spiritus Sancti, iuxta ritum Sanctae Matris Ecclesiae, episcopum solemnissime consecravimus, actui consecrationis huius pontificaliter cooperantibus Excellentissimo et Reverendissimo in Christo Domino Michaele Lewicki, archiepiscopo et metropolitano Leopoliensi ritus Graeco-Catholici, et Illustrissimo ac Reverendissimo Samuele Stefanowicz, archiepiscopo Leopolitano ritus Armeni. [...] In residentia nostra archiepiscopali Leopoli, die 24⿳亠口冋 Aprilis 1840.

\section{8}

\section{Zachariasiewicz (Zachariaszewicz) Grzegorz biskup (Gniezno [Lowicz]) sakra 2 VII 1809 (niedziela) $\cdot$ Warszawa ${ }^{174}$}

Archiwum Kapituty Lowickiej, XII. A.1.14, s. 92 (Testimonium consecrationis). Zob. równiez tamże, s. 85 (,, exhibitis gratiae pro suscipiendo munere consecrationis ab uno antistite, de die 6. Aprilis 1809, nec non literis de peracta consecratione Varsaviae sub die 3. Julii 1809”), 91 (,, Gregorius Zachariaszewicz, electus Corycensis, a Sanctitate Vestra humiliter supplicat, pro facultate suscipiendi munus consecrationis ab uno antistite, sibi assistentibus duobus dignitatibus aut canonicis sive praelatis presbyteris in ecclesiastica dignitate constitutis. [...] Die 6. Aprilis 1809. [...] Sanctissimus benigne annuit pro gratia iuxta preces non obstantibus")

[Nos] Antoninus Andreas Pobog Malinowski, Dei et Apostolicae Sedis gratia episcopus Cinnensis, suffraganeus Mednicensis, abbas commendatarius Premetensis, universis et singulis praesentes literas visuris et lecturis notum facimus et attestamur. Quia nos vigore literarum apostolicarum de datum: Romae, apud Sanctam Mariam Maiorem, anno Incarnationis Dominicae millesimo octingentesimo nono, sexto Calendas Aprilis, emanatarum, ope Divina adiuti, munus consecrationis Illustrissimi et Reverendissimi Domini Gregorii Zachariaszewicz, electi episcopi Corycensis, recepto prius ab eodem iuxta formam praescriptam, ac sub praenominatis literis apostolicis introdu[c]tam et submissam, in manibus nostris emisso solito fidelitatis iuramento, in ecclesia monialium Ordinis S. Benedicti de Perpetua Adoratione Sanctissimi Sacramenti hic Varsaviae, Dominica sexta post Pente-

${ }^{174}$ Zob. Nitecki, kol. 503-504; Polonica, s. 202, nr 257. 
costes, quae fuit dies secunda mensis Julii anni currentis, servato per omnia ritu in Pontificali Romano praescripto explevimus, assistentibus in locum episcoporum, vigore dispensationis apostolicae sub die 6. Aprilis anni currentis emanatae, consecrationi huiusmodi Illustrissimis, Reverendissimis Dominis Thomae Ostaszewski, episcopo nominato Plocensi, canonico cathedrali Posnaniensi ac cancellario Varsaviensi, Ordinis S. Stanislai equite, et Joanne Woronicz, abbate commendatario Landensi, canonico cathedrali Varsaviensi. Quibus literis manu nostra subscriptis sigillum nostrum est impressum. Varsaviae, die tertia mensis Julii, anno Domini millesimo octingentesimo nono.

\section{9}

Zajerski Franciszek biskup (Euck)

sakra 9 X $1622 \cdot$ Wtoclawek $^{175}$

$A D W t, 2-A B K P$ 18(37), k. 287r

Trigesima mensis Septembris [1622] discessit [episcopus Vladislaviensis] Volboriam et tandem die quinta Octobris pervenit Vladislaviam. Ubi sequenti die Dominica [poprawione na Dominico], qui [poprawione na qua] erat decima [sic!] eiusdem mensis munus consecrationis Reverendissimo Domino Francisco Zaierski, episcopo Argiviensi et suffraganeo Luceoriensi, assistentibus sibi Reverendissimis Dominis Baltazaro Mieszkowski, Vladislaviensi, et Stanislao Starczewski, Plocensi, suffraganeis aliisque praelatis et canonicis ecclesiae cathedralis impedit.

\section{0}

Załuski Andrzej Stanisław biskup (Płock - Łuck - Chełmża - Kraków) sakra 13 II 1724 (niedziela) • Jasna Góra [Częstochowa] ${ }^{176}$

AKMK, LOrd 8, s. 34

Die 13. Februarii [1724], quae fuit Dominica Septuagesima, Illustrissimus et Reverendissmus [episcopus Cracoviensis] in ecclesia Clarimonti Częstochoviensis, ante maius altare, infra missarum solemnia, consecravit in episcopum Illustrissimum et Reverendissimum Dominum Andream de Załuskie Załuski, electum Plocensem, cum assistentia Illustrissimorum et Reverendissimorum Francisci Krzyskowski [recte Kraszkowski], episcopi [pozostawiono miejsce na wpisanie nazwy stolicy tytularnej], suffraganei Gnesnensis, et Felicis Szaniawski, episcopi Cap-

${ }^{175}$ Zob. Szostkiewicz, s. 592; Nitecki, kol. 504.

${ }^{176}$ Por. Przybyszewski, s. 247. Zob. także Szostkiewicz, s. 592-593; Dola (I), s. 285, nr 61; Nitecki, kol. 506; Wiadomości, s. 327 (tamże przyp. 134); Polonica, s. 202, nr 258. 
sensis, suffraganei Leopoliensis, nominati Chełmensis, in praesentia multorum magnatum et populi.

$$
A J G, 537, \text { s. } 514
$$

[Dies] 13. Februarii 1724. Consecratio solennis Illustrissimi Domini Andreae Załuski, episcopi Plocensis, ante maius altare, propter angustum locum, in Sacello Mariano peracta, per Celsissimum principem episcopum Cracoviensem in assistentia Illustrissimi Domini Felicis Szaniawski, suffraganei Leopoliensi, nominati Chełmensi, et Reverendissimi Domini Kraszkowski, suffraganei Gnesnensi, abbatis K. [inicjat pozostawiono bez rozwiazania]. Post consecrationem cantabatur Hymnus Ambrosianus penes resonantiam artileriae praesidiorum fortalitii et concertum capellae domesticae, post devotionem, tam sub tempus prandii quam collationis, dabatur salve ex tormentis bellicis.

AJG, 193, s. 264[196] (tamże również wcześniejsze zapiski pod data 11 II 1724: „Celsissimus princeps Constantinus Szaniawski, episcopus Cracoviensis, dux Severiae, Illustrissimus Szaniawski, episcopus nominatus Chetmensis, Illustrissimus Szaniawski, castellanus Lublinensis, Reverendissimus Delamars, infulatus Tarnoviensis, officialis Lublinensis, et alii praelati Cracovienses ante prandium comparuerunt. Horis pomeridianis venit Illustrissimus Andreas Załuski, episcopus nominatus Ptocensis, qui antecedenter hic primitias suas celebravit, nunc consecrationis suae, in hoc loco sacro sub protectione Matris Thaumaturgae actum instituit"; oraz pod mylna data 16 [recte 12] II 1724: „Ad eundem actum venit etiam Illustrissimus et Reverendissimus Kraszkowski, episcopus suffraganeus Gnesnensis, Reverendissimus Narzemski, canonicus cathedralis Vladislaviensis, Reverendissimus Karsnicki, infulatus Lascensis, Illustrissimus Zatuski, praefectus culinae Magni Ducatus Lithuaniae, Illustrissimus Zatuski, canonicus Cracoviensis, et alli Illustrissimi Zatuscÿ, Ossolinscÿ etc. etc., quibus omnibus subsistentia data est intra moenia monasterii")

[Dies] 13. Februarii 1724. Celsissimus princeps episcopus Cracoviensis, in assistentia Illustrissimorum episcopi nominati Chełmensis et suffraganei Gnesnensis ac aliorum praelatorum, Illustrissimum episcopum Płocensem, tempore missae cantata, more solenni consecravit.

\section{1}

Zatuski Marcin (starszy) biskup (Ptock) sakra 30 IX 1696 (niedziela) $\cdot$ Warszawa ${ }^{177}$

ADPt, AEp 47(82), k. 284r-286v (Actus consecrationis Perillustris et Reverendissimi Domini Martini Załuski, episcopi Rozmensis, suffraganei Plocensis)

${ }^{177}$ Zob. Szostkiewicz, s. 593-594; Nitecki, kol. 507. 
Anno a Nativitate Domini Nostri Jesu Christi millesimo sexcentesimo nonagesimo sexto [...], die vero Dominica, quae erat trigesima mensis Septembris, Varsaviae, in ecclesia Patrum Capucinorum, dioecesis Posnaniensis, hora decima ante meridiem, [...] coram Excellentissimo, Illustrissimo et Reverendissimo Domino Andrea Chrisostomo in Załuskie Załuski, Dei et Apostolicae Sedis gratia episcopo Plocensi, intra missarum solennia, ad altare maius in pontificalibus sedente, constitutus personaliter Illustrissimus et Reverendissimus Martinus Załuski, electus et confirmatus [episcopus] Rosmensis, praesentavit et exhibuit literas sive mandatum apostolicum se a quocunque antistite Catholico in episcopum consecrandi [...]. Itaque praefatus electus episcopus post exhibitum mandatum apostolicum se in episcopum consecrari petiit. Assistentibus Illustrissimis et Reverendissimis Dominis Nicolao Popławski, episcopo Livoniae et Piltensi, abbatiae Obrensi perpetuo administratore, decano Plocensi et Varsaviensi, [et] Constantino Zielinski, episcopo Hieropolitano, suffraganeo Gnesnensi, archidiacono Pultoviensi, hoc idem postulantibus, $[\ldots]$ recepto itaque iuramento idem qui supra Illustrissimus et Reverendissimus Dominus consecrator episcopus Plocensis, una cum allis superius recensitis Illustrissimis et Reverendissimis Dominis episcopis ad consecrationem praefatam $[\ldots]$ processit et eam peregit $[\ldots]$.

\section{2}

Załuski Marcin (młodszy) biskup (Ptock)

sakra 27 VII 1732 (niedziela) $\cdot$ Warszawa ${ }^{178}$

AKapMK, LA 36, s. 27

Anno Domini 1732, die 27. mensis Julii, Varsaviae, in ecclesia insignis collegiatae Varsaviensis S. Joannis Baptistae, Dominica $8^{\mathrm{va}}$ post Pentecosten, [episcopus Luceoriensis Joannes Alexander Lipski] consecravit Illustrissimum et Reverendissimum Dominum, Dominum Martinum Załuski, episcopum Dresdensem, suffraganeum Plocensem.

\section{3}

Zatuski Pawet Antoni biskup (Ptock)

sakra 19 VII 1711 (niedziela) • Bielany [Warszawa] ${ }^{179}$

ADPt, AEp 49[73], k. 130r-132r (Actus consecrationis Reverendissimi Domini Martini [sic!] Zatuski, episcopi Arbensis)

${ }^{178}$ Por. „Diario Ordinario”, nr 2375 z 22 X 1732, s. 5; Wiadomości, s. 328 (tamże przyp. 136); Korytkowski, t. 4, s. 431. Zob. także Szostkiewicz, s. 594; Nitecki, kol. 507; Przybyszewski, s. 250 251.

${ }^{179}$ Zob. Szostkiewicz, s. 594; Nitecki, kol. 507. 
Anno a Nativitate Domini Nostri Jhesu Christi millesimo septingentesimo undecimo [...], die vero decima nona mensis Julii, quae erat Dominica octava post Pentecosten [...], in ecclesia Patrum Camedulensium prope Varsaviam, in magna frequentia Christifidelium [...], coram Illustrissimo et Reverendissimo Domino Ludovico in Załuskie Załuski [...], episcopo Plocensi, intra missarum solemnia, ante altare maius in pontificalibus sedente, constitutus personaliter Reverendissimus Dominus Paulus Antonius Załuski, electus Arbensis episcopus [...], exhibitum mandatum apostolicum se in episcopum consecrarii petiit, assistentibus sibi Illustrissimis et Reverendissimis Dominis Michaële Bartholomaeo in Czekarzowice Tarło, episcopo Posnaniensi, et Severino Szczuka, episcopo Joppensi, suffraganeo, archidiacono, vicario in spiritualibus et officiali generali Culmensi et Pomeraniae, hoc idem postulantibus [...]. Illustrissimus et Reverendissimus Dominus Ludovicus in Załuskie Załuski [...], episcopus Plocensis, consecrator, receptor iuramento [fidelitatis], una cum aliis suprarecentis dominis episcopis ad consecrationem eiusdem electi Arbensis [...] processit et eam rite et legitime peregit.

\section{4}

Zamoyski Jerzy biskup (Chełm/Krasnystaw)

sakra 27 V 1601 (niedziela) $\cdot$ Warszawa ${ }^{180}$

ADWt, 3-ASWtP 1(63cz), k. 64r

[Episcopus Margaritensis et suffraganeus Wladislaviensis Franciscus Łąnczki], vigesima secunda Maii [1601], Wladislavia Warszaviam discendens oppidum Czirviensko conveniendi Reverendissimi Domini Gregorii Zamoyski, nominati Chelmensis, causa divertit, eundemque continuato itinera Varsaviam usque comitatus, die Dominico, qui fuit 27. Maii in ecclesia collegiata Varsaviensi in episcopum Illustrissimo et Reverendissimo Claudio Rangono, episcopo Regii et S. Sedis Apostolicae ad Regnum Poloniae nuncio consecratori cum Reverendissimo suffraganeo Plocensi assistens consecravit. Inde postera die Vladislaviam versus navigis iter repetiit.

\section{5}

Zbaski Jan Stanisław biskup (Przemyśl - Warmia) sakra 22 V $1678\left(\right.$ niedziela) $・$ Kielce $^{181}$

${ }^{180}$ Por. Pawelec, cz. 6, s. 392-393, nr 28. Zob. także Szostkiewicz, s. 594; Dola (I), s. 258, nr 23; Nitecki, kol. 508.

${ }^{181}$ Por. Polonica, s. 203, nr 260. Zob. także Szostkiewicz, s. 595; Dola (I), s. 290, nr 43; Nitecki, kol. 511. 
AKMK, AEp 65, k. 569r (Consecratio episcopi Praemysliensis. Solis XXII. Maii, Kielciis)

Illustrissimus et Reverendissimus Dominus Andreas Trzebicki, Dei et Apostolicae Sedis gratia episcopus Cracoviensis, dux Severiae, Dominica sexta post Pascha, infra Octavam festi Ascensionis Domini, die 22 $2^{\text {da }}$ mensis Maii, anno 1678, [...] Illustrissimum et Reverendissimum Dominum Joannem Stanislaum Zbąski, archidiaconum Gnesnensem, custodem Sandomiriensem, abbatiae Suleioviensis Ordinis Cisterciensium perpetuum administratorem, per Sacram Regiam Maiestatem nominatum et per Sanctam Sedem Apostolicam provisum episcopum Praemysliensem, ad titulum eiusdem episcopatus Praemysliensis in ecclesia collegiata Kielcensi, intra missarum solemnia, in magna frequentia hominum diversi status et conditionis, assistentibus Illustrissimo et Reverendissimo Domino Stanislao Hyacintho Święcicki, episcopo Chełmensi, [tum] Perillustri et Reverendissimo Domino Nicolao Oborski, episcopo Laodicensi, suffraganeo Cracoviensi, servatis omnibus et singulis solemnitatibus et ceremoniis in Pontificali Romano de consecratione episcopi praescriptis et expressis, et alias, canonice ritu solenni consecravit.

\section{6}

de Zehmen Karol Ferdynand biskup (Warmia) sakra 8 IX 1765 (niedziela) • Lidzbark Warmiński ${ }^{182}$

AAWO, AB H 37a, s. 130-131

Anno 1765 Virginis Mariae, Heilsbergae, in capella arcis, a Celsissimo principe episcopo invitatus Illustrissimus et Reverendissimus Dominus Andreas Bayer, episcopus Culmensis, cum omni solemnitate consecravit in episcopum suffraganeum Varmiensem Perillustrem, Reverendissimum Dominum Carolum baronem de Zehmen, praepositum canonicum ecclesiae cathedralis Varmiensis, assistentibus Celsissimo principe loci ordinario [mowa o Adamie Stanisławie Grabowskim] et Illustrissimo ac Reverendissimo Domino Fabiano Pląskowski, suffraganeo Culmensi, in praesentia trium reverendissimorum canonicorum cathedralis Varmiensis et duorum Culmensis ecclesiarum, unius collegiatae Guttstadiensis, archipresbyteri Heilsbergensis, et aliorum novem presbyterorum, nec non multorum aulicorum. Durarunt hae ceremoniae ab hora octava matutina usque ad decimam.

${ }^{182}$ Zob. Szostkiewicz, s. 596; Nitecki, kol. 513. 


\title{
177
}

\author{
Ziegler Grzegorz Tomasz biskup (Tyniec/Tarnów - Linz) \\ sakra 29 VI 1822 (sobota) $・$ Wiedeńn 183
}

ASV, Archivio Concistoriale, Processus Consistorialis, vol. 225, k. 382r-v

[Nos] Rudolphus Joannes, Dei gratia caesareus princeps et archidux Austriae, regius princeps Hungariae atque Bohemiae, S.R.E. titutli S. Petri in Monte Aureo cardinalis, archiepiscopus Olomucensis, princeps dux et regiae capellae Bohemiae comes $[\ldots]$, universis et singulis $[\ldots]$ tenore praesentium fidem facimus, nos anno reparatae salutis MDCCCXXII, in festo Sanctorum Apostolorum Petri et Pauli, die III. Calendarum Julii, in ecclesia parochialis aulica Viennae de titutlo Beatissimae Virginis Mariae et Sancti Augustini, sub sacrosancto missae sacrificio [...], assistentibus nobis Reverendissimis in Christo Patribus, Domino Augustino Gruber, episcopo Labacensi, [...] et Domino Matthiae Paulo Steindl, episcopo Antinopolitano, suffraganeo Viennensi, Reverendissimum in Christo, nobis dilectum Dominum Gregorium Thomam Ziegler, presbyterum Ordinis S. Benedicti, Sacrae Theologiae doctorem, $[k .382 v]$ nominatum et confirmatum episcopum Tyniciensem, postquam iuramentum fidelitatis praescriptum praestitit, solemniter consecrasse. [...] Olomucii, Vํ№narum Maii anno Domini MDCCCXXVII.

178

Zienkowicz Mikołaj Jan biskup (Żmudź/Miedniki - Wilno)

sakra 6 XII 1718 (wtorek) $\bullet[?]^{184}$

APBern, S-Wi-4, s. 30

Natus anno Domini 1670, die 8. Octobris, sacerdos factus anno 1695, canonicus cathedralis Vilnensis anno 1698, consecratus est in suffraganeum Samogitiensem 1718, die 6. Decembris. Tandem sacram episcopatus Vilnensis sedem ascendit anno 1730.

\section{9}

Zienkowicz Tomasz biskup (Wilno [Białoruś])

sakra 9 XI 1755 (niedziela) $\cdot$ Wilno $^{185}$

${ }^{183}$ Por. Polonica, s. 204, nr 264 (także, nr 265). Zob. również Dola (I), s. 294, nr 2; Kumor, Diecezja tarnowska, s. 256; Nitecki, kol. 514-515.

${ }^{184}$ Zob. Szostkiewicz, s. 596-597; Nitecki, kol. 515-516; Wiadomości, s. 328 (tamże przyp. 137); Polonica, s. 204, nr 266.

${ }^{185}$ Por. Wiadomości, s. 328; J. Kurczewski, Kościół zamkowy czyli katedra wileńska w jej dziejowym, liturgicznym, architektonicznym i ekonomicznym rozwoju, t. 3 - Streszczenie aktów kapituty 
CVIA, F 1135 ap 20, k. 58r

[Die] 9. Novembris 1755, Dominica 25 a Pentecoste, in cathedrali ecclesia [Vilnensi], Illustrissimus et Reverendissimus Dominus Thomas Zienkowicz, Sacrae Theologiae et iuris utriusque doctor, custos cathedralis Vilnensis, notarius Magni Ducatus Lithuaniae, consecratus est in episcopum Ariopolitanum, suffraganeum per Albam Russiam, ab Illustrissimo et Reverendissimo Domino Antonio Tyszkiewicz, episcopo Samogitiae, assistentibus Illustrissimo et Reverendissimo Domino Antonio Żółkowski, suffraganeo Vilnensi, et Illustrissimo, Reverendissimo Alexandro Horain, suffraganeo Samogitiae.

Lietuvos Mokslu Akademijos Biblioteka (Wilno), F9 162-166, k. $61 r$

9. Novembris 1755 . W niedzielę 25-tą po [Zielonych] Świątkach, za dojściem rzymskich indultów, biskup żmudzki, senior kanoników wileńskich, umyślnie sprowadzony, przy obecności Jaśnie Wielmożnego pasterza najzasłużeńszego Michała Jana Zienkowicza, łącznie z biskupami allalieńskim Antonim Żółkowskim, oficjałem etc., i hireneńskim Aleksandrem Horainem, sufraganem żmudzkim, uroczystym w katedrze obrzędem prałata kustosza wileńskiego, sufragana białoruskiego etc., na biskupstwo arijopolitańskie, Tomasza Zienkowicza (brata biskupa wileńskiego) pokonsekrował wobec całej kapituły, ze świeckim i zakonnym duchowieństwem, oraz Jaśnie Wielmożnych magnatów i senatorów etc.

180

Żarnowiecki Stanisław Teodor biskup (Poznań)

sakra 6 IV 1806 (niedziela) • Poznań ${ }^{186}$

AAPzn, CP 64, k. 166v (Consecratio Illustrissimi Żarnowiecki in episcopum Laucensem)

Celsissimus, Illustrissimus et Reverendissimus Dominus [Ignatius] comes Raczyński, episcopus Posnaniensis, nominatus archiepiscopus Gnesnensis, Ordinum Aquilae Nigrae et S. Ioannis Hierosolymitani eques, convertando benevolentiam suam erga personam Illustrissimi et Reverendissimi Domini Stanislai Żarnowiecki, praepositi Posnaniensis, ob praeclara merita in dioecesim totamque Rempublicam Christianam, eudem primo suffraganeum dioecesis suae Posnaniensis constituit, ac tandem die 6. Aprilis anno praesenti 1806 in ecclesia cathedrali Posnaniae, ipso scilicet die Paschalis, in episcopum Leucensem consecravit, assistentibus ad sacra

wileńskiej, Wilno 1916, s. 340; Kasabuła, Ignacy Massalski, biskup wileński, s. 147. Zob. także Szostkiewicz, s. 597; Nitecki, kol. 516.

${ }^{186}$ Por. Nowacki, t, 2. s. 191, nr 37; A. Weiss, Raporty dziekanów o stanie kościołów diecezji poznańskiej w 1797 roku, Lublin 2010, s. 59 (całość biogramu - s. 56-60). Zob. również Nitecki, kol. 521; Polonica, s. 204, nr 268. 
caeremonias Illustrissimo, Excellentissimo et Reverendissimo Domino Stanislao Łubieński, episcopo Bibliensi et suffraganeo Gnesnensi, Ordinis Aquilae Albae equite, tum Illustrissimo Stanislao Kierzkowski, abbate claustrali Ordinis S. Benedicti Lubinensi, praesentibus quam plurimis magnatibus ac fere totius civitatis Posnaniae civibus ad hunc actum solemnissimum congregatis.

$$
\text { AAPzn, ASO 14, k. } 6 \mathrm{v}
$$

Anno 1806, Dominica Resurrectionis Domini nostri Jesu Christi, quae fuit dies sexta mensis Aprilis, infra missarum solemnia, in ecclesia cathedrali Posnaniensi, [ordinarius loci Ignatius Raczyński] ordinavit et consecravit Illustrissimum et Reverendissimum Dominum Stanislaum de Żarnowiecki, canonicum cathedralem Posnaniensem, in episcopum Leucensem in partibus [infidelium].

\section{1}

Żegocki Krzysztof Jan biskup (Chełm/Krasnystaw)

sakra [?] $1671 \cdot[?]^{187}$

Archiwum Archidiecezjalne w Lublinie, Rep.60 A 151, k. 277v

A Serenissimo Joanne Casimiro palatinus Inovladislaviensis creatus, tandem episcopus Chełmensis in coronatione [Michaelis Korybuth] a Serenissimo rege praesentatus, ab Illustrissimo episcopo Vladislaviensi assistentibus Illustrissimo et Reverendissimo Domino Stanislao Swięcicki, episcopo postea Chełmensi tertio successore, et Reverendissimo suffraganeo Gnesnensi consecratus [est]. Laboriosus in Ecclesia Dei [et] zelozus in cultu eius promovendi, [...] nam a suo sacro incipiendo primo quod in coronatione die festoque Beati Stanislai Kostka Cracoviae celebravit usque ad ultimam diem obitus sui quotidie ad aras praevia diuturna devotione visus sacra peragere.

\section{2}

Żótkowski Antoni biskup (Wilno [Białoruś'])

sakra 21 II 1745 (niedziela) • Wilno ${ }^{188}$

Lietuvos Mokslu Akademijos Biblioteka (Wilno), F9 162-166, k. 61r

21. Februarii 1745. Ku szczęśliwemu zaskutecznieniu bull rzymskich, Jaśnie Wielmożni biskupi wileński Michał Jan Zienkowicz i żmudzki Antoni Tyszkie-

${ }^{187}$ Por. Pawelec, cz. 6, s. 395, nr 38; W. Sauter, Krzysztof Żegocki, pierwszy partyzant Rzeczypospolitej, 1618-1673, Poznań 1981, s. 129 („konsekracji dokonał książę Florian Czartoryski dopiero w roku 1671"). Zob. także Szostkiewicz, s. 597; Dola (I), s. 258, nr 30; Nitecki, kol. 522.

${ }^{188}$ Por. Wiadomości, s. 328 (tamże przyp. 138); Kurczewski, Kościół zamkowy czyli katedra wileńska, t. 3, s. 324. Zob. także Szostkiewicz, s. 597; Nitecki, kol. 522. 
wicz z inflanckim Józefem Puzyną, jako swoimi spółkonsekratorami, przy obecności całego duchowieństwa i ludu, spełnili akt uroczystej konsekracji na biskupstwo allalieńskie in partibus prałata dziekana i oficjała generalnego wileńskiego, Św. Teologii i praw obojga doktora Antoniego Żółkowskiego, czego mu akademicy jezuiccy z uczniami szkoły pijarskiej przez wyborne panegiryki z najczulszą życzliwością powinszowali.

\section{3}

Żyliński Wacław Kazimierz biskup (Wilno - Mohylów) sakra 17 XII [5 XII st.st.] 1848 (niedziela) • Sankt Petersburg ${ }^{189}$

ASV, Archivio Concistoriale, Processus Consistorialis, vol. 254, b.p.

[Nos] Casimirus Dmochowski, [...] archiepiscopus Mohiloviensis et metropolitaneus Ecclesiarum Romano-Catholicarum in Imperio Rossiae [...], universis et singulis [... [ fidem indubiam facimus et significamus: qualiter nos, visa et diligenter lecta copia bullarum Sanctissimi Domini Nostri Pii Papae IX [...], in qua apostolica auctoritate cuilibet episcopo, in communione Ecclesiae Catholicae existenti, conceditur facultas nomine Sanctissimi Papae munus consecrationis episcopalis Illustrissimo et Reverendissimo Domino electo Vilnensi Venceslao Żyliński conferendi [...], eundem Illustrissimum et Reverendissimum Dominum Venceslaum Żyliński [...], opem ferentibus Illustrissimis ac Reverendissimis Dominis Antonio Fiałkowski, episcopo Hermopolitano, suffraganeo Plocensi, vicario capituli et administaratore sede vacante archidioecesis Varsaviensis, Josepho Joachimo Goldmann, episcopo Sandomiriensi, Ignatio Hołowiński, episcopo Caristonensi et coadiutore Mohiloviensi, nec non Gaspare Borowski, episcopo Luceoriensi et Żytomiriensi, [...] intra missarum solemnia [...] in episcopum Vilnensem rite consecravimus anno Incarnationis Dominicae millesimo octingentesimo quadragesimo octavo, mensis Decembris die 5. veteris styli, quae fuit Dominica secunda Adventus, in ecclesia parochiali Sanctae Catharinae Virginis et Martyris sub regimine Patrum Ordinis Praedicatorum.

$* * * * *$

\section{4}

Isakowicz Izaak Mikołaj arcybiskup (Lwów) sakra 27 VIII 1882 (niedziela) • Lwów ${ }^{190}$

${ }^{189}$ Por. Polonica, s. 204, nr 269 (również, nr 270); Wasilewski, Arcybiskupi i administratorowie, s. 72. Zob. także Dola (I), s. 298, nr 32; Nitecki, kol. 523-524.

${ }^{190}$ Por. Z. Obertyński, Katalog unickich arcybiskupów ormiańskich w Polsce, w: Historia Kościoła $w$ Polsce, t. 2 cz. 2, Poznań - Warszawa 1979, s. 312, nr 13; T. Zaleski, Słownik biograficzny duchownych ormiańskich oraz duchownych rzymskokatolickich pochodzenia ormiańskiego $w$ Polsce w latach 1750-2000, Kraków 2001, s. 51. 
ASV, Archivio Nunziatura di Vienna, vol. 587, k. 348r (list arcybiskupa I.M. Isakowicza do nuncjusza wiedeńskiego z daty: Lwów, 30 VIII 1882)

Divina favente gratia actus consecrationis et introductionis meae in sedem archiepiscopalem Leopoliensem ritus Armeni Catholici per Illustrissimum ac Reverendissimum Dominum Albinum Dunajewski, episcopum Cracoviensem ritus Latini, in assistentia Reverendissimorum episcoporum Severini Morawski, ritus Latini, et Silvestri Sembratowicz, ritus Graeci, peracta est elapsa Dominica, die videlicet vigesima septima mensis et anni currentis. Iuramenta fidei praescripta ante consecrationem et palii impositionem, publice emissa, per me et Reverendissimum consecratorem subscripta et signata, per eundem Dominum Albinum Dunajewski, episcopum consecratorem meum, Sedi Apostolicae devotissime substernuntur.

\section{5}

Jaworowski Leon biskup (Brześć [Włodzmierz])
sakra 27 I [15 I st.st.] 1811 (niedziela) • Połock ${ }^{191}$

AGAD, Dział III, zespót 358; 3153, s. 143-144/149-150 (kopia dokumentu)

[Nos] Gregorius Kochanowicz, Dei miseratione et Sanctae Sedis Apostolicae benedictione Graeco-Unitorum in Rossia Ecclesiarum metropolita, episcopus Luceoriensis, universis et singulis praesentes visuris, lecturis, legive audituris, singulariter vero Tibi Illustrissimo, Reverendissimo Domino Leoni Jaworowski, suffraganeo Brestensi, episcopo Vlodimiriensi, salutem omnemque prosperitatem in Domino praecamur. [...] Cumque onus dignitatis [s. 144] metropoliticae a Sua Maiestate humeris nostris licet imparibus impositum portemus, attentoque impossibili recursu ad Sanctam Sedem Apostolicam propter notis [nadpisane notas] universim temporum calamitatibus [nadpisane calamitates], quibus nos Omnipotens voluit Sua oprimi iustitia, ita ut exequi per nos in bulla Clementis VIII. praefixam conditionem, ut nominatus suprema potestate vel electus ab eadem Sede Apostolica quaerat confirmationem nedum valeremus, verum quomodo ut ubi Sanctissimum Pontificem motum a Sua Sede expetere et eius benedictionem expostulare poteremus, consulendo in nomine Domini, quantum nostra imbecillitas attingit, ab omnibus episcopis nostrae vocationis unitis anno MDCCCX, die 5. mensis Januarii, in vigilia Theophaniae, Petropolim actum submissionis nostrae filialis erga Romanum Pontificem cum fecerimus [poprawione $z$ fecimus], ac proinde anno currenti $1811^{\circ}, 1^{\text {a }}$ die mensis Januarii, in ecclesia cathedrali Polocensi in facie Ecclesiae ante consecrationem Illustrissimi Reverendissimi Domini Joannis Krassowski in archiepiscopum Polocensem expleverimus [poprawione $z$ explevi-

${ }^{191}$ Por. D. Blazejowskyj, Hierarchy of the Kyivan Church (861-1990), Romae 1990, s. 260, 293 , 307; D. Blazejowskyj, Іерархія Київської Церкви (861-1996), Львів 1996, s. 260, 293, 307; R. Dobrowolski, Opat supraski biskup Leon Ludwik Jaworowski, Supraśl 2003, s. 86-87 (§ 5.4. Chirotonia). 
mus], forma in Synodo Zamosciana praescripta, et iuraverimus [poprawione $z$ iuravimus] fidei Catholicae professionem, Te abbatem Suprasliensem Ordinis Sancti Basilii Magni ad consecrandum in suffraganeum Brestensem et episcopum Vlodimiriensem accessimus [...]. [s. 149] Adveniente tandem die Dominica, scilicet decima quinta die Januarii, in ecclesia cathedrali Polocensi, in conspectu populi recepta a Te fidei Catholicae professione [...], assistentibus Illustrissimis Reverendissimis Dominis Joanne Krassowski, archiepiscopo Polocensi, Josaphat Bułhak, episcopo dioecesano Brestensi, et Adriano Hołownia, episcopo Orsensi, nostro suffraganeo Vilnensi, intra pontificalium solemnia Te in suffraganeum Brestensem [nadpisane: et episcopum Vladimiriensem] [...] consecravimus. [...] Polociae, die $15^{\text {ta }}$ mensis Januarii 1811 anno.

\section{6}

Krassowski Jan arcybiskup (Połock)

sakra 13 I [1 I st.st.] $1811 \cdot$ Połock $^{192}$

AGAD, Dziat III, zespót 358; 3153, s. 241-243 (kopia dokumentu)

[Nos] Gregorius Kochanowicz, Dei miseratione et S. Sedis Apostolicae benedictione Graeco-Unitarum Ecclesiarum in Rossia metropolita, Dei miseratione episcopus Luceoriensis, universis et singulis praesentes visuris, lecturis, legive audituris, singulariter vero Tibi Illustrissimo, Excellentissimo, Reverendissimo Domino Joanne Krassowski, archiepiscopo Polocensi, episcopo Vitebscensi et Mscislaviensi, salutem omnemque prosperitatem in Domino praecamur. [...] Cum onus dignitatis metropoliticae a Sua Maiestate humeris nostris licet imparibus impositum portemus, habita prius authentice producta legitima Augustissimi, Invictissimi Alexandri Primi, imperatoris et authocratoris totius Rossiae, domini nostri clementissimi, nominatione in archiepiscopum Polocensem post obitum piae memoriae Illustrissimi, Reverendissimi Domini Heraclii Lissowski, metropolitae et archiepiscopi Polocensi, de die $N N$ anno 1809 emanata, [s. 242] [...] adveniente tandem die Dominica et simul festo Circumcisionis Ihesu Christi, die scilicet $1 \frac{\mathrm{ma}}{}$ Januarii [1811], in ecclesia cathedrali Polocensi, in conspectu magni cleri [...], facta prius nobis et iurata in facie Ecclesiae professio fidei Catholicae forma in Synodo Zamosciana praescripta et per protonotarium apostolicum et officialem generalem Polocensem, Perillustrem Reverendissimum Dominum Thomam Rodziewicz, consignata, [...] assistentibus denique Illustrissimis Reverendissimis Dominis Josaphat Bułhak, Rutheno-Unito diaecesano Brestensi, Jacobo Dederko, diaecesano Minscensi, et Cypriano Odyniec, suffraganeo Polocensi, ritus Latini, episcopis, intra pontificalem solemniam, in archiepiscopum Polocensem perpetuum et irrevocabilem Te consecravimus [...]. [s. 243] Polociae, 1811 anno, 4. die Januarii.

${ }^{192}$ Por. Dola (II), s. 309, nr 12; Blazejowskyj, Hierarchy of the Kyivan Church, s. 267, 285-286; Blazejowskyj, Іерархія Киӥвської Церкви, s. 267, 285. 


\section{7}

Lewicki Józef biskup (Chełm) sakra 5 VII [24 VI st.st.] 1711 (niedziela) • Lwów ${ }^{193}$

AGAD, Dziat VI, II-79, k. 100v

[Dnia] 5. Julii [1711] była w katedrze ruskiej [we Lwowie] konsekracya Jmci Xiędza Lewickiego na episkopię chełmską, po ktorej częstował wszystkich Jmć Xiądz Winnicki, metropolita ruski y episkop przemyski.

\section{8}

Lewicki Michat metropolita (Przemyśl - Halicz/Lwów) sakra 20 IX [8 IX st.st.] 1813 (poniedziałek) • Lwów ${ }^{194}$

ASPF, Scritture riferite nei Congressi. Moscovia - Polonia-Ruteni, vol. 19, k. 78r-v (Litera consecrationis et institutionis Illustrissimi ac Reverendissimi Michëlis Lewicki ac cathedram episcopalem ritus Graeco-Catholici Premisliensem, Samboriensem et Sanocensem [odpis]); zob. również: tamże, $k$. 84r

[Nos] Antonius Angellowicz, Divina miseratione metropolita Haliciensis, archiepiscopus Leopoliensis, episcopus Kamenecensis, vacantis episcopatus Premisliensis, Samboriensis et Sanocensis generalis in spiritualibus administrator [...], universis et singulis [...] significamus praesentibus [...], quod [...] $[k .78 v]$ adveniente die octava Septembris veteris, et vigesima eiusdem mensis novi styli anni currentis [1813], Illustrissimum ac Reverendissimum Dominum Michaëlem Lewicki, nominatum episcopum Premisliensem, Samboriensem et Sanocensem ritus Graeco-Catholici, in archicathedrali nostra ecclesia Leopoliensi tituli S. Georgii Martyris, ad conspectum plurimorum magnatum et nobilium frequentisque cleri et populi confluxum, exaudita illius professione fidei Catholicae prestitaque Romano Pontifici, nobis metropolitano archiepiscopo et sucessoribus nostris subiectione et obedientiae contestatione, intra pontificalium solemnia ritu Orientali, assistente Excellentissimo, Illustrissimo ac Reverendissimo Domino Joanne Simonowicz, archiepiscopo ritus Armeni Leopoliensi, [...] in praememoratae Ecclesiae Premisliensis, Samboriensis et Sanocensis episcopum et pastorem consecravimus [...]. Datum Leopoli, in palatio nostro metropolitano ad ecclesiam ar-

${ }^{193}$ Por. Dola (II), s. 305, nr 10 (data sakry 4 VII 1711); Blazejowskyj, Hierarchy of the Kyivan Church, s. 264, 303 (,,consecrated in Peremyšl 24.6 / 4.7.1711”); Blazejowskyj, Іерархія Київської Церкви, s. 264, 303; A. Gil, Chetmska diecezja unicka 1596-1810. Dzieje i organizacja, Lublin 2005, s. 98 („,wyświęcony na biskupa przez metropolitę [Innocentego] Winnickiego w Przemyślu 4 VII 1711").

${ }^{194}$ Por. Dola (II), s. 309, nr 12; Blazejowskyj, Hierarchy of the Kyivan Church, s. 312, 318; Blazejowskyj, Іерархія Київської Церкви, s. 312, 318. Nadto: S. Nabywaniec, Uniccy biskupi przemyscy w latach 1610-1991. Szkice biograficzne, Rzeszów 1995, s.56-60. 
chicathedralem Sancti Georgii Martyris, die vigesima mensis Septembris, millesimo octingentesimo decimo tertio anno.

\title{
189
}

\section{Lissowski Herakliusz arcybiskup (Polock) sakra 18 IV [7 IV st.st.] 1784 (niedziela) $・$ Norduchowicze ${ }^{195}$}

\begin{abstract}
ASV, Segreteria di Stato. Polonia, Add. 19, b.p (list arcybiskupa H. Lissowskiego do legata G.A. Archettiego z daty: Orsza, [?] IV 1784). Zob. również tamże, b.p. (list legata G.A. Archettiego do Kurii Rzymskiej z daty: Sankt Petersburg, 13 II 1784: „Sta ora attendendo con impazienza i riscontri si di Polocko in Bianca Russia dall'abbate Onufriense, futuro arcivescovo, che di Pinsko in Lituania da Monsignor Horbacki, vescovo di Rito Greco-Unito, al qualo io già spedii per pregarlo di portarsi con ogni sollecitudine in Polocko a consagrare il detto abbate, ed installarlo in quella cattedra"); b.p. (list legata G.A. Archettiego do kardynała L.O. Pallaviciniego z daty: Sankt Petersburg, 16 IV [5 IV st. st.] 1784: „L'aver il principe Potemkin desiderato, che la consacrazione del nuovo arcivescovo di Polocko si facesse nella chiesa del monastero di Lubavice, situato sulle sue terre”); b.p. (list legata G.A. Archettiego do kardynała L.O. Pallaviciniego z daty: Sankt Petersburg, 30 IV [19 IV st. st.] 1784: „Con un corriere spedito qua dal Signor principe Potemkin si è saputo, che Monsignor vescovo di Pinsko aveva consagrato nella chiesa del monastero di Lubawice il Polocense [arcivescovo] Lissowski; quindi partito il sudetto Monsignor vescovo di Pinsko, e giunto in Mohilovia avea finito di vivere rapito da violento male nel breve spazio di due giorni. [...] Piango la perdita del più degno prelato tra $i$ vescovi di Rito Greco-Unito della Polonia”); b.p. (list legata G.A. Archettiego do kardynała L.O. Pallaviciniego z daty: Sankt Petersburg, 7 V [26 IV st. st.] 1784: „La notizia d'esser gia eseguita la consagrazione ed installazione del nuovo arcivescovo di Polocko, che ebbi già l'onore di portare alla cognizione di Vestra Eccellenza col mio ultimo foglio, mi è stata confermata con lettera dello stesso prelato")
\end{abstract}

Litteris ab Excellentia Vestra Petropoli anno praesente die 8/19. Martii datis postulatum est, ut Excellentiam Vestram certiorem redderem de habita consecratione. Huic postulationi, ut morem geram, notum facio: consecrationem meam in ecclesia vici dicti Norduchowicze ditionis Suae Serenitatis principis Gregorii Alexandrowicz Potemkin, supremi mareschalli, ad postulationem atque in praesentia illius, assistentibus Illustrissimis archiepiscopo Mohiloviensi eiusque coadiutore, nec non duobus ritus nostris abbatibus, Polocensi atque Leszczanensi, 7. Aprilis, die Dominica Antipaschae dicta, peractam esse. Illustrissimus consecrator, episcopus Pinscensis [et] metropoliae coadiutor Gedeon Horbacki, tussi ac

${ }^{195}$ Por. Wiadomości, s. 308 (tamże przyp. 64); Dola (II), s. 309, nr 11; Blazejowskyj, Hierarchy of the Kyivan Church, s. 256-257, 284-285 (,was consecrated in St. Petersburg on 18.4.1784 by Bishop Jakym Horbac'kyj of Pins'k"); Blazejowskyj, Іерархія Київської Церкви, s. 256-257, 284285 (gdzie dodatkowo omyłka drukarska w dacie rocznej sakry: 18.4.1884). Nadto: Epistolae metropolitarum Kioviensium Catholicorum: Theodosii Rostockyj, Heraclii Lisowskyj, Gregorii Kochanowicz, Josaphat Bulhak - 1788-1838, coll. A.G. Welykyj, Romae 1980, s. 147-148. 
${ }^{\mathrm{a}}[\ldots]^{-a}$ icedine gravissime laborans, viribusque enervasus praeter spem et expectationem omnium, longiori functioni suffecit. At aegritudinem suam auxit victimaque religioni cecidit, Orsae diem extremum obiens die 11. Aprilis stili veteris $^{196}$.

\section{0}

Litwinowicz Spirydon metropolita (Halicz/Lwów - Halicz/Lwów) sakra 17 V [5 V st.st.] 1857 (niedziela) • Wiedeń ${ }^{197}$

ASV, Archivio Concistoriale, Processus Consistoriales, vol. 259, b.p

[Nos] Joannes Lemény, Divina miseratione et Sanctae Sedis Apostolicae gratia [...] episcopus Graeco-Unitus Fogarasiensis, universis et singulis [...] notum testatumque facimus, quod postquam Sanctissimus Dominus Noster Divina providentia Pius Papa IX Illustrissimum ac Reverendissimum Dominum Spiridionem Litwinowicz, capituli metropolitani Leopoliensis canonicum et ecclesiae parochialis ad S. Barbaram Viennae rectorem ab Eminentissimo ac Reverendissimo Domino Michaële cardinali Lewicki, metropolita Haliciensi et archiepiscopo Leopoliensi Ruthenorum, in auxiliarem seu suffraganeum episcopum electum, [...] in episcopum Ecclesiae Canathensis in partibus infidelium eo cum apostolico indultu praeconisare ac confirmare dignatus esset $[\ldots]$, nos $[\ldots]$ eundem Illustrissimum ac Reverendissimum Dominum Spiridionem Litwinowicz die Dominica quarta post Resurrectionem Christi Domini, quae fuit decima septima (17a) mensis Maii anno Domini millesimo octingentesimo quinquagesimo septimo (1857), in ecclesia parochiali S. Barbarae Viennae [...], assistentibus Illustrissimis ac Reverendissimi Dominis episcopis Latini ritus et quidem episcopo Diocletianopolitano et vicario apostolico Caesareo-Regii exercitus Michaële Leonhard, item episcopo Sareptano et suffraganeo Viennensi Francisco Xaverio Zenner, in episcopum $[\ldots]$ inter missae sacrificium solemni ritu consecravimus.

\section{1}

Sembratowicz Józef metropolita ([Przemyśll] - Halicz/Lwów) sakra 11 VI [30 V st.st.] 1865 (niedziela) $・$ Lwów ${ }^{198}$

a- a wyraz nieczytelny.

196 Por. Wiadomości, s. 302 (tamże przyp. 38); Dola (II), s. 308, nr 13 (Gedeon Horbacki zm. przed 10 VII 1784); Blazejowskyj, Hierarchy of the Kyivan Church, s. 255, 279; Blazejowskyj, Іерархія Київської Церкви, s. 255, 279.

${ }^{197}$ Por. Blazejowskyj, Hierarchy of the Kyivan Church, s. 313; Blazejowskyj, Іерархія Київської Церкви, s. 313. Zob. również Dola (II), s. 307, nr 10; Polonica, s. 182, nr 121.

${ }^{198}$ Por. Blazejowskyj, Hierarchy of the Kyivan Church, s. 313, 319; Blazejowskyj, Іерархія Київської Церкви, s. 313, 319. Zob. również Dola (II), s. 307, nr 11; Polonica, s. 194, nr 203. 
ASV, Archivio Concistoriale, Processus Consistoriales, vol. 263, b.p.

[Nos] Spiridion Litwinowicz, Divina miseratione et Sanctae Sedis Apostolicae gratia Ruthenorum Unitorum metropolita Haliciensis, archiepiscopus Leopoliensis, episcopus Kamenecensis, Suae Sanctitatis praelatus domesticus et Solio Pontificio assistens, Sacrae Congregationis de Propaganda Fide in negotiis ritus Orientalis consultor, Suae Cesareo-Regiae et Apostolicae Maiestatis actualis intimus consiliarius, Sacrae Theologiae doctor etc,. omnibus, quorum interest, notum testatumque facimus, quod nos dilectum in Christo Fratrem Illustrissimum et Reverendissimum Dominum Josephum Sembratowicz, presbyterum saecularem dioecesis Graeco-Ruthenae Premisliensis, Sacrae Theologiae doctorem et in Universitate Leopoliensi professorem publicum ac ordinarium, per litteras apostolicas Sanctissimi Domini Pii Papae IX [...] archiepiscopum Nazianzenum in partibus infidelium electum et confirmatum [...], die decima [recte undecima] Junii anno millesimo octingentesimo sexagesimo quinto -10 . Junii 1865 , quae fuit prima Dominica post Pentecosten, inter missarum solemnia in ecclesia nostra archicathedrali metropolitana S. Georgii Martyris, assistentibus nobis consecratoribus Excellentissimo ac Reverendissimo Domino Francisco Xaverio de Wierzchleyski, archiepiscopo Leopolieni Latini ritus, et Illustrissimo ac Reverendissimo Domino Gregorio Szymonowicz, archiepiscopo Leopoliensi Armeni ritus, ritu pontificali Orientalibus praescripto sacro ordini episcopali initiavimus atque in archiepiscopum Nazianzenum consecravimus. [...] Leopoli, die 11. Junii 1865.

\section{2}

Stupnicki Jan biskup (Przemyśl)

sakra 20 X [8 X st.st.] $1872\left(\right.$ niedziela) $\bullet$ Lwów ${ }^{199}$

Archiwum Państwowe w Przemyślu, zespół 143; 411, s. 27 (Testimonium consecrationis z daty: Leopoli, die 8/20. Octobris 1872). Zob. również tamże, s. 43-64 (zwt. s. 43)

[Nos] Josephus Sembratowicz, Divina miseratione et S. Sedis Apostolicae authoritate metropolita Haliciensis, archiepiscopus Leopoliensis, episcopus Kamenecensis $[\ldots]$, omnibus, quorum interest, notum testatumque facimus, quod nos dilectum in Christo Fratrem Illustrissimum ac Reverendissimum Dominum Joannem de Saturnus Stupnicki, canonicum gremialem capituli metropolitani ritus Graeco-Catholici Rutheni Leopoliensis [...], in episcopum Graeco-Catholicum Ruthenum Premisliensem, Samboriensem et Sanocensem nominatum [...], confirmatum et institutum [...], die octava veteris styli, 20. vero Octobris novi styli anno millesimo octingentesimo septuagesimo secundo, quae fuit decima octava Dominica post Pentecosten, inter missarum solemnia in ecclesia nostra archi-

${ }^{199}$ Por. Dola (II), s. 309, nr 16; Blazejowskyj, Hierarchy of the Kyivan Church, s. 320; Blazejowskyj, Іерархія Київської Церкви, s. 320; Nabywaniec, Uniccy biskupi przemyscy, s. 74-75. 
cathedrali metropolitana S. Georgii Martyris, assistentibus nobis conconsecratoribus Excellentissimis ac Reverendissimis Dominis Francisco Xaverio de Wierzchlejski, archiepiscopo Leopoliensi Latini ritus, Gregorio Michaele Szymonowicz, archiepiscopo Leopoliensi Armeni ritus, nec non Reverendissimo episcopo Graeco-Catholico Rutheno Chelmensi Domino Michaele Kuziemski, pontificali ritu Orientalibus praescripto sacro ordine episcopali initiavimus atque in episcopum Graeco-Catholicum Ruthenum Premisliensem, Samboriensem et Sanocensem consecravimus.

\section{3}

Szumborski Filip Felicjan biskup (Chełm)

sakra 16 V [4 V st.st.] $1830\left(\right.$ niedziela) $\bullet$ Chetm $^{200}$

ASPF, Scritture riferite nei Congressi. Moscovia-Polonia-Ruteni, vol. 19, k. $716 \mathrm{v}$ $717 r$ (adnotacja urzędowa na formularzu Iuramentum fidelitatis - przysiegi wykonanej podczas aktu sakry biskupiej na ręce głównego konsekratora).

Nos infrascripti Mauritius Mathaeus Wojakowski, episcopus Arcadiopolitanus, suffraganeus Lublinensis, et Franciscus Lewiński, episcopus Eleuteropolitanus, suffraganeus Podlachiensis, omnibus et singulis quorum interest fidem facimus et attestamur, quod anno a Nativitate Domini Nostri Jesu Christi $[k$. 717r] millesimo octingentesimo trigesimo, Dominica quarta post solemnitatem Resurrectionis Christi, iuxta ritum Ecclesiae Ruthenae Unitae, die vero decima sexta mensis Maii novi stili, constitutus personaliter Illustrissimus Dominus Philippus Felicianus binominis Szumborski, coram Illustrissimo ac Reverendissimo Domino Vincentio Siedlecki, episcopo Bełzensi, suffraganeo et administratore sede vacante episcopatus Chełmensis generali, consecratore, $[. .$.$] in ecclesia cathedrali Chełmensi$ supra expressum charactere Slavico iuramentum [...] in manibus eiusdem supra memorati consecratoris praestitit [...], praesentibus Reverendissimis Dominis Paulo Szymański, Sacrae Theologiae doctore, praelato decano capituli Chełmensis, Daniele Stalicki, canonico chartophylace cathedrali, aliisque praelatis et canonicis utriusque ritus, testibus. Actum Chełmae, anno Domini MDCCCXXX, die 16. Maii.

\section{4}

Śnigórski (Snigurski) Jan biskup (Przemyśl) sakra 30 VIII [18 VIII st.st.] 1818 (niedziela) • Przemyśl $^{201}$

${ }^{200}$ Por. Dola (II), s. 305, nr 16 (data sakry 16 III 1830); Blazejowskyj, Hierarchy of the Kyivan Church, s. 305 (,consecrated on 16.3.1830 by Bishop Sedlec'kyj and two Latin rite bishops”); Blazејоwskyj, Іерархія Київської Церкви, s. 305.

${ }^{201}$ Por. Dola (II), s. 309, nr 13; Blazejowskyj, Hierarchy of the Kyivan Church, s. 319; Blazejowskyj, Іерархія Київської Церкви, s. 319; Nabywaniec, Uniccy biskupi przemyscy, s. 62. 
ASPF, Scritture riferite nei Congressi. Moscovia-Polonia-Ruteni, vol. 19, k. 348-v (pismo metropolity halickiego i arcybiskupa lwowskiego obrzadku grecko-katolickiego Michała Lewickiego do Kongregacji Rozkrzewiania Wiary z daty: Lwów, 16 II 1819).

Postquam me, antea episcopum Premisliensem, Samboriensem et Sanocensem, ritus Graeco-Catholici, a Serenissimo imperatore Austriae Francisco I. ad sedem metropolitanam Haliciensem, post defunctum Antonium Angellowicz, ultimum eius antistitem, vacantem, nominari literisque Sacrae Sedis Apostolicae [...] a vinculo Ecclesiae Premisliensis praeesse tenebar, absolvi, in archiepiscopum Haliciensem et Leopoliensem confirmari et ad sedem metropolitanam gratiosissime tranferri contigisset, Sua Caesareo-Regia Apostolica Maiestas ad vacantem dehinc episcopatum Premisliensem, Samboriensem et Sanocensem Joannem Snigurski, presbyterum dioecesis Premysliensis, Sacrae Theologiae doctorem, canonicum Premisliensem, parochum ecclesiae ritus Graeco-Catholici Vindobonensis ad S. Barbaram, pro tempore Facultatis Theologicae in Universitate Vindobonensi decanum, nominari dignata est. Hunc itaque nominatum Joannem Snigurski, praemisso processu canonico perspectaque eius ad regendam Ecclesiam Premisliensem idoneitate, $[k .348 v]$ die 30. mensis Augusti anno 1818 in cathedra Premisliensi ritus Graeco-Catholici tituli S. Joannis Baptistae, assumpto in consecratorem Illustrissimo ac Reverendissimo Domino Antonio Gołaszewski, episcopo Premisliensi Latinorum, in episcopum Premisliensem, Samboriensem et Sanocensem ritus Graeco-Catholici consecravi consecratumque installavi. Atque de his ita peractis Sacrae Congregationis humilissime referro [...]. Leopoli, die 16. Februarii 1819.

\section{5}

Teraszkiewicz Jan biskup (Chetm [Betz])

sakra 21 V [9 V st.st.] 1843 (niedziela) $\bullet$ Chetm $^{202}$

ASPF, Scritture riferite nei Congressi. Moscovia-Polonia-Ruteni, vol. 20, k. 197-v (pismo biskupa chetmskiego F.F. Szumborskiego do papieża Grzegorza XVI z daty: Chetm, 10 VI 1843)

Die 21. Maii anni currentis [ego Philippus Felicianus Szumborski], subsignatus episcopus Chełmensis ritus Graeco-Catholici uniti, auxilio Dei adiutus, ad mentem brevis Vestrae Sedis Apostolicae de die 30. Augusti 1842 anno, ad personam meam directi, consecravi in episcopum Bełzensem simulque suffraganeum Chelmensem Admodum Reverendum Joannem Taraszkiewicz [sic!], praelatum custodem capituli cathedralis nec non rectorem et professorem seminarii dioecesis me-

${ }^{202}$ Zob. także Dola (II), s. 305, nr 17; Blazejowskyj, Hierarchy of the Kyivan Church, s. 305; Blazejowskyj, Іерархія Київської Церкви, s. 305. 
ae Chełmensis, invitatis ad opus hocce sacrum duobus episcopis ritus Latini, qua conconsecratoribus, scilicet Illustrissimo ac Reverendissimo Domino Valentino Tomaszewski, episcopo Kujavo-Calisiensi, tum Illustrissimo et Reverendissimo Domino Paulo Straszynski, episcopo Augustoviensi, praesente copioso clero utriuseque ritus magnoque numero nobilium et populi adiacentis provintiae.

ASPF, Scritture riferite nei Congressi. Moscovia - Polonia - Ruteni, vol. 20, k. 198r-v (Testimonium consecrationis)

[Nos] Philippus Felicianus Szumborski, Dei et Sanctae Apostolicae Sedis gratia episcopus Chelmensis, Matthias Valentinus Tomaszewski, Dei et Sanctae Apostolicae Sedis gratia episcopus Calissiensis seu Vladislaviensis, [et] Paulus Straszynski, Dei et S. Apostolicae Sedis gratia episcopus Augustoviensis, universis et singulis [...] significamus, [...] [quod] requisiti fuimus ab Illustrissimo ac Reverendissimo Domino Joanne Teraszkiewicz, quatenus in vim executionis brevis apostolicae ipsum in episcopum Bełzensem et suffraganeum Chelmensem, qui in pontificalibus exercendis aliisque pastoralibus muniis obeundis episcopo Chelmensi adiumento esse possit, promovere et consecrare digneremur. Nos huiusmodi supplicationibus, uti iustis, benigne annuentes, recepta prius ab eo solita professione fidei $[\ldots]$ [et] iuramento fidelitatis, [...] [k. 198v] servatis omnibus solennitatibus munus consecrationis ipsi impendimus die 21. Maii anni currentis. [...] Dabatur ad cathedram Chelmensem, die 21. Maii 1843.

\section{6}

Tumanowicz Jakub Walerian arcybiskup (Lwów)

sakra 29 IV $1770\left(\right.$ niedziela) $・$ Dunajów ${ }^{203}$

AGAD, Dziat III, zespót 396; 247, k. 71v-72r

Anno Domini 1770, die 29. Aprilis, quae fuit Dominica IV. post Pascha, in ecclesia praepositurali Dunajoviensi, [archiepiscopus Leopoliensis Venceslaus Hieronymus Sierakowski] consecravit solenni ritu Illustrissimum et Reverendissimum Jacobum Valerianum Tumanowicz ad episcopatum Camacensem pro coadiutore Illustrissimi et Reverendissimi Jacobi Augustynowicz, archiepiscopi Leopoliensis ritu Armenorum, assistentibus sibi suprascripto Illustrissimo et Reverendissimo Augustynowicz, et Illustrissimo ac Reverendissimo Raymundo Jezierski, episcopo Baccoviensi.

${ }^{203}$ Obertyński, Katalog unickich arcybiskupów, s. 312, nr 7; Zaleski, Słownik biograficzny duchownych ormiańskich, s. 104-105. 


\title{
SOURCE EXTRACTS FOR THE BIOGRAPHY OF POLISH BISHOPS AND ABBOTS \\ FROM THE TIME OF THE POLISH-LITHUANIAN COMMONWEALTH AND THE PARTITIONS OF POLAND (16TH AND 19TH CENTURIES). (PART X)
}

\begin{abstract}
Summary
The tenth part of the cycle for Source extracts for the biography of the Polish bishops and abbots from the time of the Polish-Lithuanian Commonwealth and the Partitions of Poland is entirely dedicated to the testimonies of the ordination of bishop representatives of the Old Polish Catholic episcopate at various times and circumstances. These testimonia consecrationis were taken from different categories of sources-primarily from (acta sacrarum functionum), from the books acta episcopalia, acta actorum capituli, records of informative process concerning bishoprics, from correspondence and diaries-only unpublished. These testimonies refer to the group of 195 hierarchs (including 11 of the Greek Catholic rite, 2 the Armenian Catholic Rite and the rest-the Latin rite), but when it comes to particular centuries these testimonies are presented as follows: 15 th. $-4,16$ th. -7 , 17 th $-43,18$ th $-91,19$ th -50 . So far, there has been no information where and when a large number of bishops were consecrated, so the following work, presenting substantial portion of factual data acquired directly from archive material, contributes enormously to the state of research on this issue.
\end{abstract}

